Illinois State University

ISU ReD: Research and eData

Theses and Dissertations

3-29-2018

\title{
Los pronombres de segunda persona del singular y la cortesía verbal en español peninsular y en euskera
}

Gorka Basterretxea Santiso

Illinois State University, gorkabs@gmail.com

Follow this and additional works at: https://ir.library.illinoisstate.edu/etd

Part of the Anthropological Linguistics and Sociolinguistics Commons

\section{Recommended Citation}

Basterretxea Santiso, Gorka, "Los pronombres de segunda persona del singular y la cortesía verbal en español peninsular y en euskera" (2018). Theses and Dissertations. 840.

https://ir.library.illinoisstate.edu/etd/840

This Thesis is brought to you for free and open access by ISU ReD: Research and eData. It has been accepted for inclusion in Theses and Dissertations by an authorized administrator of ISU ReD: Research and eData. For more information, please contact ISUReD@ilstu.edu. 


\title{
LOS PRONOMBRES DE SEGUNDA PERSONA DEL SINGULAR Y LA CORTESÍA VERBAL EN ESPAÑOL PENINSULAR Y EN EUSKERA
}

\author{
Gorka Basterretxea Santiso
}

105 Páginas

Resumen

A través de los pronombres de segunda persona del singular se pueden establecer una serie de relaciones personales entre los hablantes en cada idioma. Abundantes trabajos han sido ya publicados en relación a esta cuestión lingüística tanto en español como en euskera, sobre todo para delimitar sus ámbitos de uso, pero en ningún caso se han realizado estudios comparativos dentro de la pragmática intercultural sobre estos dos idiomas vecinos a este respecto. Tomando como punto de partida los pronombres de segunda persona del singular del español peninsular -tú y usted-y los del euskera $-h i$ y $z u-$, el presente trabajo realiza una comparación de creaciones de relaciones personales a través de ellos, con la utilización del marco teórico de la cortesía lingüística de Brown y Levinson (1987). El análisis del español peninsular se ha basado en estudios empíricos ya publicados, mientras que los datos del euskera se han obtenido a través de los diálogos de la serie Goenkale. De esta forma, con el presente estudio se concluirán las diferencias o similitudes entre ambos idiomas en referencia a la creación de relaciones personales mediante el uso de sus correspondientes pronombres de segunda persona del singular.

PALABRAS CLAVE: cortesía; hi; relación; tú; usted; zu. 


\section{Laburpena}

Bigarren pertsona singularreko izenordainen bitartez hainbat eratako harremanak ezarri daitezke hiztunen artean hizkuntza bakoitzean. Lan ugari kaleratu dira dagoeneko gai linguistiko honen inguruan bai gaztelaniaz bai euskaraz, batez ere beraien erabilerak mugatzeko, baina oraindik ez da konparaziozko lanik kaleratu kulturarteko pragmatikaren baitan hizkuntz auzotar bi hauen artean. Beraz, gaztelaniazko -tú eta usted- eta euskarazko - hi eta $z u$ - bigarren pertsona singularreko izenordainak abiapuntu bezala harturik, lan honek pertsonen arteko harremanen eraketak alderatuko ditu beraien bitartez, Brown eta Levinsonen (1987) hitzezko-kortesia teoriaren kontzeptuak oinarritzat hartuz. Konparaketarako, gaztelaniazko partea dagoeneko argitaratutako ikerketa enpirikoetan oinarritu da, eta euskarazko datuak Goenkale telesaileko elkarrizketetatik batuak izan dira. Honela, lan honekin harremanen eraketari buruzko hizkuntza bien arteko ezberdintasunak edo berdintasunak ondorioztatuko dira bakoitzari dagozkion bigarren pertsona singularreko izenordainen bidez.

HITZ GAKOAK: kortesia, hi; elkarren arteko harremana; tú; usted; zu.

\section{Abstract}

The use of second person singular pronouns is one way that speakers of a language manage their interpersonal relationships. A number of studies have already been published in relation to this topic both in Spanish and in Basque, mainly to delimit their scope of uses, but in no case have comparative studies regarding these two neighboring languages been developed within intercultural pragmatics. Taking the second person singular pronouns of Peninsular Spanish -tú and usted-and of Basque - hi and $z u$ - as the point of departure, the present study examines how these pronouns are implicated in interpersonal relationships, using Brown and 
Levinson's (1987) politeness theory as the theoretical framework. In comparing pronoun use in both languages, the data on Spanish pronouns is based on already published empirical studies, while the data on Basque pronouns comes from the dialogues of a Basque-language television series called Goenkale. The present study will draw conclusions about the differences and similarities between Spanish and Basque with regard to how speakers negotiate interpersonal relationships through the use of second person singular pronouns.

KEYWORDS: politeness; hi; interpersonal relation; tú; usted; zu. 
LOS PRONOMBRES DE SEGUNDA PERSONA DEL SINGULAR Y LA CORTESÍA VERBAL EN ESPAÑOL PENINSULAR Y EN EUSKERA

GORKA BASTERRETXEA SANTISO

\author{
A Thesis Submitted in Partial \\ Fulfillment of the Requirements \\ for the Degree of \\ MASTER OF ARTS \\ Department of Languages, Literatures, and Cultures \\ ILLINOIS STATE UNIVERSITY
}

2018 
(C) 2018 Gorka Basterretxea Santiso 
LOS PRONOMBRES DE SEGUNDA PERSONA DEL SINGULAR Y LA CORTESÍA VERBAL EN ESPAÑOL PENINSULAR Y EN EUSKERA

GORKA BASTERRETXEA SANTISO

MIEMBROS DEL COMITÉ:

Rachel Shively, Presidenta

Patxi Lascurain-Ibarlucea

Montserrat Mir 


\section{AGRADECIMIENTOS}

En primer lugar, me gustaría dar especialmente las gracias a la Dra. Shively por aceptar mi propuesta de escribir la tesis bajo su dirección en un tiempo bastante limitado, y por su generosidad, eficacia, y disponibilidad absoluta para el trabajo. Ha sido gratificante poder trabajar contigo mano a mano durante estos meses. También me gustaría agradecer su trabajo a los otros dos miembros de mi comité. Primero, a la Dra. Mir por ayudarme tanto durante estos dos años que he pasado en Illinois State University. De no ser por ti, nunca hubiera solicitado plaza en el Master del Departamento de Lenguas, Literaturas y Culturas. Espero que sigas reclutando y ayudando tanto a otros muchos como yo. En segundo lugar-los últimos siempre serán los primeros-al Dr. Lascurain-Ibarlucea por su constante ayuda y sus consejos impagables. Patxi, no sé si eres consciente de lo que te apreciamos y de cuánto agradecemos tu compañía: mila esker! Gracias también a los tres por ayudarme tanto con mi futuro académico. Espero seguir en contacto con los tres.

Tampoco me puedo olvidar de mi familia en general, pero en especial de mi vínculo más cercano: ama, aita, y Nora. Gracias por apoyarme siempre en conseguir lo que me propongo (aunque sea lejos de nuestra casa) tanto dentro como fuera del mundo académico. Eskerrik asko! Y por supuesto a mis amigos.

G. B. S. 


\section{CONTENIDOS}

Página

AGRADECIMIENTOS i i

CONTENIDOS

$\begin{array}{ll}\text { TABLAS } & \text { iii }\end{array}$

CAPÍTULO I: INTRODUCCIÓN

CAPÍTULO II: REVISIÓN DE LA LITERATURA 6

$\begin{array}{ll}\text { Teoría de la Cortesía: Brown y Levinson } & 6\end{array}$

La Deixis Personal y Social del Español Peninsular 16

$\begin{array}{ll}\text { TÚ } & 18\end{array}$

$\begin{array}{ll}\text { USTED } & 24\end{array}$

La Deixis Personal y Social del Euskera $\quad 29$

$\begin{array}{ll}\text { HI } & 34\end{array}$

$\begin{array}{ll}\text { ZU } & 40\end{array}$

Objetivo y Preguntas de Investigación $\quad 42$

CAPÍTULO III: METODOLOGÍA

CAPÍTULO IV: RESULTADOS

$\begin{array}{ll}\text { Las Parejas } & 55\end{array}$

$\begin{array}{ll}\text { La Amistad } & 61\end{array}$

$\begin{array}{ll}\text { La Familia } & 69\end{array}$

$\begin{array}{ll}\text { Asimetría de Poder Social } & 81\end{array}$

CAPÍTULO V: DISCUSIÓN Y CONCLUSIONES $\quad 88$

$\begin{array}{ll}\text { REFERENCIAS } & 98\end{array}$ 


\section{TABLAS}

Tabla

Página

1. Categorización de los personajes por edad

2. Número de personas con diferente tipo de relación

3. Los usos de $h i$

4. Los usos de $z u$ 


\section{CAPÍTULO I: INTRODUCCIÓN}

A través de los pronombres de segunda persona del singular de cada idioma se establecen relaciones personales diferentes, por ejemplo, relaciones íntimas, solidarias, respetuosas, o distantes. Además, con la inevitable evolución de las lenguas, los usos de los pronombres de segunda persona del singular también cambian y, por consiguiente, se transforma también la creación de relaciones personales. Tomando los pronombres de segunda persona del singular del español de la Península Ibérica -tú y usted- y el euskera - $h i$ y zu-, como puntos de partida, estos pronombres han vivido desarrollos diferentes a lo largo de su historia pudiendo afectar a la creación de relaciones personales.

De hecho, las investigaciones del español han hecho evidente que los pronombres de segunda persona del singular han evolucionado en cuanto al número de uso, a favor de tú (Ardila, 2003; Blas Arroyo, 1995, 2005a; Carricaburo, 1997; de Jonge y Nieuwenhuijsen, 2012; León-Castro Gómez, 2014; Moliner, 1977; Soler-Espiauba, 1994). En euskera, el número de uso de los pronombres de segunda persona del singular también ha evolucionado notablemente, principalmente en detrimento de $h i$, aunque aparentemente, el cambio en euskera no ha sido tan destacable como en el español peninsular, al menos durante los últimos quinientos años (Alberdi, 1991, 1995; de Rijk, 1991; Echeverria, 2003; Euskaltzaindia, 1985; Trask, 2003; Zubiri y Zubiri, 2000).

Muchos estudios han sido ya publicados a este respecto en las dos lenguas ya mencionadas, pero dentro de la pragmática intercultural, pocos han establecido -siempre dentro de mi conocimiento- comparaciones entre los pronombres de segunda persona del singular de estos dos idiomas vecinos, en cuanto a la creación de relaciones interpersonales. Con todo esto, y teniendo en cuenta que a través de los pronombres de segunda persona del singular se codifican 
las relaciones personales entre los interlocutores (Blas Arroyo, 2005b), el presente trabajo es un estudio sincrónico del siglo XXI con el objetivo de examinar la creación de dichas relaciones con un análisis de los pronombres tú, usted, $h i, \mathrm{y} z u$ en sus correspondientes lenguas, tomando como perspectiva el marco teórico de la cortesía verbal propuesta por Brown y Levinson $(1978,1987)$.

Los pronombres de segunda persona introducidos arriba constituyen formas de tratamiento que desempeñan un papel significativo en el discurso, ya que se utilizan no solo para señalar a los participantes en los actos comunicativos, sino también como recursos lingüísticos para expresar la cortesía, crear identidades sociales, señalar el punto de vista del hablante y establecer relaciones interpersonales. Esto es, los cuatro pronombres mencionados arriba forman parte de la deixis personal y social. Los pronombres de segunda persona del singular del español, pueden, por ejemplo, marcar la distancia social, el registro, y una postura más objetiva o subjetiva (Blas Arroyo, 1994; de Jonge y Nieuwenhuijsen, 2012; Lambert y Tucker, 1976; Marín, 1972; Serrano, 2017; Solé, 1978). Igualmente, los pronombres de segunda persona del singular pueden ser recursos influyentes a la hora de moldear las identidades sociales y la imagen de las personas, lo cual facilita a su vez la gestión de la imagen del hablante y del receptor (Serrano, 2017).

El estudio contrastivo que aquí se propone incluye el español de la Península Ibérica y el euskera de la Comunidad Autónoma Vasca -también denominado como el euskera occidental-, conformada por las provincias de Bizkaia, Gipuzkoa, y Araba. Este estudio se centrará solamente en la variedad del español peninsular y no en otra variedad, por su contacto con el euskera. Aun habiendo escogido estas dos lenguas y las mencionadas variedades en concreto, cada una de estas lenguas tiene aspectos lingüísticos diferentes, a pesar de ser dos lenguas que han estado -y están- en permanente contacto a lo largo de su historia. Por ello, se ha decidido estudiar los 
pronombres de segunda persona del singular del español peninsular y del euskera para, de este modo, inferir el tipo de significados implícitos que acarrean sus usos y la variedad de relaciones interpersonales que se crean a través de ellos, mediante la teoría de la cortesía (Brown y Levinson, 1978, 1987).

Como se ha mencionado al principio de este capítulo, en el español de la Península Ibérica, parece evidente que durante los últimos años ha disminuido el uso del pronombre de segunda persona del singular usted, tradicionalmente presente en ámbitos formales (Ardila, 2003; Soler-Espiauba, 1994). En cuanto al euskera, hay diferentes registros que podrían ser interpretados a través de la teoría de la cortesía verbal, pero los registros principales que utilizan los hablantes vascos son zuka e hika -en el Capítulo II se desarrolla una breve descripción de los otros registros y las razones por las que no son abordadas en el análisis de este trabajo-(Wolpert, Mancini y Caffarra, 2017).

Con este estudio se quiere realizar un análisis comparativo del español peninsular y el euskera, centrado en la teoría de la cortesía verbal de Brown y Levinson (1987). Esta teoría -la cual será desarrollada en la revisión de la literatura dentro del Capítulo II- se basa principalmente en el concepto de imagen ('face') que fue introducido por Goffman en 1967, en referencia a la imagen pública -positiva o negativa- que una persona demanda en la sociedad, la cual suele verse amenazada, mantenida o realzada, y siempre está presente en las interacciones conversacionales (Brown y Levinson, 1987).

El objetivo será, por tanto, analizar los usos de los pronombres de segunda persona del singular de cada idioma, especificando los ámbitos de uso y las características de cada hablante. Estas propiedades contextuales son esenciales en el estudio de la pragmática en general y de la cortesía verbal en particular. Mediante el uso de algunos de los conceptos básicos de la cortesía 
verbal -como por ejemplo la imagen, el mantenimiento o la amenaza del mismo, la solidaridad, el poder, y la distancia- se podrá llegar a un conocimiento explícito de qué significados implícitos acarrean sus usos y qué tipo de relaciones interpersonales se establecen, para poder hacer así una comparación de similitud o distinción entre el español peninsular y el euskera, porque en resumen, la selección de un pronombre de segunda persona del singular, es una forma de emitir o crear un significado.

La razón primordial por la que se plantea este estudio es que tal y como se ha introducido antes en este capítulo, el español de la Península Ibérica y el euskera son dos lenguas en constante contacto durante su historia, influenciándose consecuentemente mutuamente en diversos aspectos lingüísticos. Pese a este hecho, sus orígenes y sus características lingüísticas no son en absoluto parecidas, siendo interesante el desarrollo de un estudio comparativo de las dos lenguas. Además, aunque la cortesía es un ámbito de la lingüística que está en permanente estudio y evolución, parece que no se han elaborado suficientes trabajos académicos contrastivos durante el siglo XXI que comparen el uso de los pronombres de segunda persona del singular en conexión con la cortesía verbal en el español peninsular y el euskera occidental. Por eso se cree necesaria la realización de este estudio comparativo con el fin de hacer más clara la diferencia o similitud entre el español y el euskera, al menos, en cuanto a la creación de identidades o significados implícitos y relaciones interpersonales a través del uso de la cortesía verbal.

El presente trabajo será organizado en capítulos de tal forma que el Capítulo II hará una revisión de la literatura escrita sobre la cortesía verbal de Brown y Levinson (II.I.), la cual servirá de apoyo central para el consiguiente análisis. El mencionado capítulo también se centrará en la deixis personal y social del español peninsular (II.II.) y el euskera (II.III.) respectivamente, para así poder conocer en profundidad los usos establecidos de los pronombres 
de segunda persona del singular de estas dos lenguas. Después, el Capítulo III introducirá los métodos empleados en la recogida de datos para el análisis para, a continuación, en el Capítulo IV, poder realizar un análisis de los datos en cuestión. Finalmente, en el Capítulo V se creará una comparación entre el español peninsular y los datos recogidos del euskera. En este mismo capítulo se podrán encontrar las principales conclusiones extraídas de un examen exhaustivo de los datos y, de la misma forma, se pondrá la vista en futuros trabajos relacionados con la creación de relaciones interpersonales a través de los pronombres tú y usted en español, e $h i$ y $z u$ en euskera. 


\section{CAPÍTULO II: REVISIÓN DE LA LITERATURA}

En este capítulo se realiza la revisión de la literatura fundamental para el desarrollo del presente trabajo. Dicha revisión comienza con una detallada explicación de la teoría de la cortesía lingüística de Brown y Levinson (II.I.), para después poder centrar la atención en la explicación de los pronombres de segunda persona del singular, primero en el español peninsular (II.II.) y después, en euskera (II.III.). Al final de este capítulo (II.IV.), se especificará el objetivo de este estudio, así como las preguntas de investigación que se plantean para su desarrollo.

\section{Teoría de la Cortesía: Brown y Levinson}

Es necesario conocer la teoría de la cortesía lingüística de Brown y Levinson (1978; 1987) como minimización de los actos de amenaza, para analizar los significados implícitos y la creación de relaciones interpersonales entre los hablantes a través de los usos de los respectivos pronombres de segunda persona del singular en español y en euskera, ya que será la base para el análisis que se llevará a cabo en el Capítulo IV. En el presente estudio se seguirá la teoría propuesta por Brown y Levinson (1987) por ser la teoría de la cortesía más adecuada para la elaboración del presente análisis ya que se centrará, por nombrar como ejemplo, en la creación o ausencia de amenazas. Según estos autores, la cortesía presupone la existencia de una posibilidad de agresión u ofensa ya que busca aplacar dicha ofensa, facilitando de esta forma la comunicación entre partes que son potencialmente agresivas (Brown y Levinson, 1987).

Hay muchas maneras de expresar cortesía además de con las formas pronominales de segunda persona del singular - por ejemplo, a través de mitigadores como por favor en una petición, o los diminutivos añadidos al final de un sustantivo-, pero la teoría de la cortesía ayuda a analizar y entender en profundidad los usos corteses y descorteses de los pronombres tú, usted, 
$z u$, e $h i$ en sus correspondientes idiomas. Por ejemplo, con la aplicación de esta teoría se puede observar si los hablantes emplean la lengua para mantener o amenazar la armonía de las relaciones interpersonales, así como delimitar las expectativas de los usuarios en diferentes contextos. De hecho, la teoría de Brown y Levinson $(1978 ; 1987)$ ha sido definida como el resultado de la necesidad de minimizar la imposición en el destinario que surge de un acto verbal y de la consiguiente posibilidad de realizar un acto de amenaza ('face threatening act'), dicho de otra forma, una teoría de la cortesía basada en proteger la imagen ('face-saving theory'), y no como una teoría derivada de una serie de principios pragmáticos (Watts, 1992).

El concepto fundamental de la teoría de la cortesía de Brown y Levinson (1987) es el término de la imagen ('face'), introducido por Goffman en 1967. Los mencionados autores definen este concepto como la imagen pública que todos los miembros quieren reivindicar para sí mismos. Este término también lo relacionan con nociones como avergonzarse, ser humillado, o perder la imagen ('to lose face'). De esta forma, la imagen es algo que se puede perder, mantener, o realzar, y que tiene que estar siempre presente en la conversación (Brown y Levinson, 1987). Por lo general, la imagen de uno mismo depende del mantenimiento de la imagen del interlocutor y esa es la razón por la cual los participantes de una conversación suelen cooperar para mantener la imagen (Brown y Levinson, 1987). Esta imagen se divide en dos tipos de imagen social: (i) imagen negativa -el deseo de cualquier miembro adulto y competente de que sus acciones no sean impedidas por los demás-e (ii) imagen positiva -la necesidad de cualquier persona de que sus deseos sean aceptados por los demás-(Brown y Levinson, 1987).

Siendo así las cosas, Brown y Levinson (1987) creen que es evidente que algunos actos de habla -lo que se pretende hacer con una comunicación verbal o no verbal-amenazan la imagen ('face threatening acts') de forma intrínseca, sobre todo, aquellos actos que por su 
naturaleza son contrarios a los deseos de la imagen del destinatario o del oyente. Por tanto, para estos dos autores, la cortesía es el resultado de los actos de amenaza: es una acción reparadora (Albelda Marco y Barros García, 2013). Estos actos amenazadores pueden ser clasificados de distintas formas, pero una de las diferenciaciones que se pueden realizar es centrándose en los conceptos de imagen negativa y positiva, además del hablante u oyente: (i) actos que amenazan la imagen negativa del destinatario porque el hablante no tiene la intención de impedir la libertad de acción del oyente -por ejemplo, órdenes, peticiones, sugerencias, recomendaciones, recuerdos, amenazas, desafíos, ofertas, promesas, cumplidos, y expresiones de admiración o envidia-, (ii) actos que amenazan la imagen positiva del receptor-como las críticas, expresiones de desagrado, quejas, reprimendas, acusaciones, insultos, desacuerdos, expresiones de emociones violentas, irreverencias, menciones de temas tabú, y expresiones de tratamiento o identificaciones marcadas en encuentros iniciales-, (iii) actos que amenazan la imagen negativa del hablante -por ejemplo, dar las gracias, aceptar las gracias o el perdón del oyente, aceptar ofertas, y promesas u ofertas no deseadas-, y finalmente, (iv) los actos que amenazan la imagen positiva del hablante - por ejemplo, el perdón, aceptar un cumplido, humillarse, contradecirse a uno mismo, y confesión o admisión de culpa o responsabilidad-(Brown y Levinson, 1987).

En este contexto de vulnerabilidad mutua de la imagen social, cualquier agente racional buscará evitar los actos de amenaza, teniendo en cuenta la importancia relativa de al menos tres factores: (i) el deseo de comunicar el contenido del acto de amenaza, (ii) el deseo de ser eficiente o urgente, y (iii) el deseo de mantener la imagen del destinatario hasta cualquier punto (Brown y Levinson, 1987). A menos que (ii) sea más grande que (iii), el hablante querrá minimizar la amenaza del acto de habla (Brown y Levinson, 1987). 
Es interesante observar la diversidad de estrategias que se pueden seguir al realizar un acto de amenaza de acuerdo con Brown y Levinson (1987). Una de estas estrategias es decir las cosas de forma clara y sin ambigüedades ('on record'). Sin embargo, también existe la posibilidad de transmitir algo de forma ambigua y así se puede atribuir más de una intención a un acto ('off record'). La tercera posibilidad es realizar un acto sin rodeos y sin compensación ('baldly, without redress'), lo cual implica que se hace de forma más clara y directa en aquellos casos en los que el hablante no tiene miedo de ningún castigo o pena por parte del destinatario. Una posibilidad más es realizar actos correctores ('redressive action'), lo que significa que trata de contrarrestar el potencial daño que pueda causar el acto de amenaza. Dentro de este último tipo de acto, hay dos subdivisiones muy importantes en la teoría de Brown y Levinson (1987): (i) la cortesía positiva y (ii) la cortesía negativa. De forma breve se puede decir que, la primera, está orientada a la imagen positiva del destinatario - la imagen positiva que demanda para sí mismotratando a este, por ejemplo, como parte de un grupo, un amigo, o cuyos deseos se respetan; en definitiva, se minimiza la amenaza de un acto. La segunda, está orientada principalmente a satisfacer de forma parcial la imagen negativa del destinatario -su deseo de mantener el territorio y la libertad de imposición.

Empezando con (i) la cortesía positiva, esta se utiliza como una forma de extender metafóricamente la intimidad, para implicar una base común, o para compartir deseos incluso entre desconocidos que se consideran similares o iguales para los objetivos de la comunicación. Por estas razones, las técnicas de la cortesía positiva pueden ser utilizadas tanto como mitigadores de los actos de amenaza, así como aceleradores sociales, ya que el hablante puede indicar que quiere ser más cercano al oyente (Brown y Levinson, 1987). De hecho, una de las estrategias de la cortesía positiva es la muestra de afinidad ('common ground') señalando que el 
emisor y el receptor pertenecen a algún tipo de grupo en el que comparten deseos, objetivos, o valores. Esto se puede realizar mediante la indicación por parte del hablante de que le parecen interesantes o admirables los deseos de su interlocutor, enfatizando la pertenencia al grupo, o evidenciando una perspectiva común sin necesidad de ser parte de un grupo. De esta forma, los siguientes se consideran como métodos de muestra de afinidad (Brown y Levinson, 1987):

- Prestar atención a los intereses, deseos, necesidades, y bienes del oyente.

- Exagerar los intereses del interlocutor o mostrar simpatía con el oyente, por ejemplo, a través de una entonación exagerada.

- Intensificar los intereses hacia el destinatario.

- El uso de marcadores que permitan identificarse como parte del grupo. Aquí es donde se encuentran las formas de tratamiento. De acuerdo con Brown y Gilman (1960), muchos idiomas diferencian dos pronombres de segunda persona del singular que indican solidaridad (T) o respeto y distancia (V), después de los pronombres franceses $t u(\mathrm{~T})$ y vous $(\mathrm{V})$. Aparte de las formas pronominales, esta estrategia también incluye palabras como cariño, hermano, o cielo, entre otros. Por tanto, el uso de palabras como cariño y cielo, y los pronombres T, son marcadores grupales que implican que el destinatario considera que el poder relativo $(\mathrm{P})$-poder y diferencia de estatus- entre sí y su interlocutor es muy pequeño (Brown y Levinson, 1987). El uso del lenguaje grupal, jergas -por ejemplo, el uso de la terminología conocida para los miembros de un grupopuede conllevar muchas implicaciones, y las contracciones y elipsis también son parte de esta estrategia. 
- Buscar un acuerdo. Para ello se puede hablar de temas seguros o repetir lo que el interlocutor ya ha dicho.

- Evitar el desacuerdo, por ejemplo, creando pseudo-acuerdos, diciendo mentiras piadosas ('white lies'), o dando evasivas.

- Presuponer, aumentar o reivindicar la afinidad con cotilleos, con manipulación de presuposiciones - por ejemplo, presuponer el conocimiento de los deseos del destinatario con preguntas en negativo, presuponer que los valores del oyente son los mismos que los del hablante, o presuponer familiaridad en la relación entre los interlocutores.

- Bromas.

Otra estrategia de la cortesía positiva es transmitir que el hablante y el oyente son cooperadores de una actividad relevante, y por tanto, comparten objetivos pudiendo así reparar los deseos de la imagen positiva del destinatario (Brown y Levinson, 1987). La siguiente lista de estrategias forma parte de esta cortesía positiva:

- Que el hablante asevere o presuponga que conoce y se preocupa por los deseos del oyente.

- Ofrecer y prometer, mostrando que cualquier cosa que quiera el destinatario, también lo quiere el emisor.

- Ser optimista.

- Incluir al hablante y al oyente en la actividad, utilizando, por ejemplo, el pronombre nosotros.

- Dar o pedir razones. Esto hace que el oyente sea parte del razonamiento.

- Asumir o reclamar reciprocidad. 
El tercer y último tipo de estrategia positiva se centra en cumplir los deseos del oyente, marcando de esta forma que el hablante quiere o acepta los deseos del oyente para el oyente. Esto puede realizarse a través de las siguientes estrategias, las cuales no forman parte de la cortesía lingüística como tal: hacer regalos al destinatario, como bienes, simpatía, comprensión, o cooperación.

Por su parte, la función de (ii) la cortesía negativa es minimizar la imposición que causan los actos de amenaza que son inevitables (Brown y Levinson, 1987). Una de las estrategias de esta cortesía es ser directo, el cual se enfrenta a otra de las estrategias de la cortesía negativa, que es ser convencionalmente indirecto. La primera de estas estrategias deriva del aspecto de la cortesía negativa relacionado con la ausencia de ambigüedad, la segunda, así como el resto de estrategias, están relacionadas con reparar la imagen negativa del oyente. Dentro de este segundo grupo, una estrategia más es no asumir o suponer que lo que está implicado en el acto de amenaza, es lo deseado por el oyente, por lo que el hablante debería cuestionar o eludir dichas suposiciones. También se puede incluir la estrategia de no forzar o coaccionar al oyente, por ejemplo, al reclamar su ayuda. Por esto, se le puede dar la oportunidad de no hacer el acto, siendo indirecto, sin asumir que el oyente quiere realizar la acción, siendo pesimista, minimizando la imposición u ofreciendo deferencia o condescendencia.

Es importante desarrollar más la estrategia de la deferencia ya que servirá después para el análisis. Hay dos formas de marcar deferencia: el hablante puede presentarse como humilde o rebajarse, pero, por otro lado, puede realzar al oyente (Brown y Levinson, 1987). En cualquiera de los dos casos, está claro que el oyente es superior al hablante y por esta razón, al marcar la diferencia de poder $(\mathrm{P})$, la deferencia tiene la función de apaciguar los posibles actos de amenaza a la imagen, al reconocer el derecho del destinatario a la libertad de imposición. En ocasiones 
también se transmite deferencia de manera recíproca implicando respeto mutuo en una relación de amplia distancia (D). En esta sección se incluye el vocabulario honorífico del que disponen las lenguas, y también los pronombres (V) que marcan distancia y respeto.

Volviendo de nuevo a las estrategias de la cortesía negativa, la lista se sigue completando con la táctica de comunicar los deseos del hablante, en lugar de vulnerar al oyente con los siguientes métodos: pedir perdón, admitir la vulneración, indicar reticencia, abrumar con razones, o suplicar el perdón (Brown y Levinson, 1987). Hay más formas de no querer imponer al oyente, por ejemplo, mediante la transmisión de algo de forma impersonal: actos performativos, imperativos, verbos impersonales, la voz pasiva, reemplazar los pronombres yo y tú por indefinidos, utilizar el plural de yo y tú, evitar los pronombres yo y tú, y distanciarse desde el punto de vista. Incluso, se puede declarar el acto de amenaza como una regla general en la sociedad -se evita el uso de pronombres personales-y la nominalización también es útil. Finalmente, la última estrategia, y no por eso menos importante, de la cortesía negativa es reparar los deseos del oyente de forma que el hablante reconozca su deuda con el oyente o, por el contrario, defender la ausencia de alguna deuda con expresiones como 'estaré eternamente agradecido' o 'no me resulta ningún problema, lo puedo hacer' (Brown y Levinson, 1987).

Además de todas las estrategias previas, hay que tener en cuenta que la evaluación de la gravedad de un acto de amenaza implica la consideración de los siguientes factores probablemente en todas las culturas, siempre según Brown y Levinson (1987): (i) la distancia social (D) entre el hablante y el oyente -dimensión social simétrica de similitud o diferencia; a menudo se basa en la frecuencia de la interacción-, (ii) el poder relativo (P) del emisor y el destinatario - es el grado al que el destinatario puede imponer sus planes y sus evaluaciones de la imagen; hay dos fuentes: control material (por ejemplo, económico) y control metafísico sobre 
las acciones de los demás-, y (iii) el grado de imposiciones (R) en cada cultura -son imposiciones definidas culturalmente y situacionalmente por el grado con el que pueden interferir con los deseos de auto-determinación o aprobación de un agente. Proponen además una fórmula para calcular el peso de un acto de amenaza:

$$
\mathrm{W}_{\mathrm{x}}=\mathrm{D}(\mathrm{S}, \mathrm{H})+\mathrm{P}(\mathrm{H}, \mathrm{S})+\mathrm{R}_{\mathrm{x}}
$$

Brown y Levinson (1987) explicaron esta fórmula con que $\mathrm{W}_{\mathrm{x}}$ es el valor numérico que mide el peso de un acto de amenaza, $\mathrm{D}(\mathrm{S}, \mathrm{H})$ es el valor que mide la distancia social entre el hablante y el oyente, $\mathrm{P}(\mathrm{H}, \mathrm{S})$ es la medida de poder entre el oyente y el hablante, y finalmente, $\mathrm{R}_{\mathrm{x}}$ es el valor que contabiliza el grado por el que el acto de amenaza es un índice de imposición en la cultura. Es así una fórmula de suma que suele funcionar bien, pero reconocen a su vez que algunos valores más complejos pueden verse involucrados (Brown y Levinson, 1987).

No obstante, es destacable que, aunque esta teoría sea una de las más extendidas en la actualidad, su grandeza está relacionada, según expertas como Albelda Marco y Barros García (2013), con que fue la primera teoría sobre la cortesía lingüística. Esta es una de las razones por las que Brown y Levinson $(1978,1987)$ han recibido numerosas críticas que se detallarán a continuación. Por ejemplo, estudiosas como Bravo $(1999,2003)$ han ofrecido alternativas con términos como 'autonomía' y 'afiliación' como parte de la imagen social de las personas. Efectivamente, Albelda Marco y Barros García (2013) defienden el concepto de la imagen social como universal y, consecuentemente, componente básico de las personas, aunque la diferenciación entre imagen negativa y positiva no ha sido puesta en evidencia. Además, una de las principales críticas que han recibido Brown y Levinson (1987) es sin duda debido al carácter universal de su teoría, echando sus raíces en la lengua inglesa (Albelda Marco y Barros García, 2013; Leech, 2014; Watts, 2003). Finalmente, también han recibido numerosas críticas por su 
aptitud para culturas individualistas, pero no para las culturas que dan importancia a la afiliación colectiva como puede ocurrir en la cultura china o japonesa (Leech, 2014).

Aun siendo consciente de estas críticas y aunque a lo largo de los años se hayan ofrecido diferentes teorías sobre la cortesía (Fraser y Nolen, 1981; Gu, 1900; Ide, 1982, 1989, 1993; Lakoff, 1973, 1990; Leech, 1977, 1980, 1983; Spencer-Oatey, 2000; Watts, 1989, 1992, 2003) se adoptará aquí la teoría de la cortesía lingüística de Brown y Levinson $(1978,1987)$ por diversas razones. Una de ellas se debe a que, tal y como presentan Albelda Marco y Barros García (2013), Brown y Levinson no creen que la cortesía esté vinculada a normas prescriptivas o a un contrato conversacional entre los hablantes, sino a las necesidades particulares que pueda tener cada participante en la conversación. Esto es considerado como una ventaja porque los vínculos sociales entre los hablantes se ven mantenidos y reforzados, al tener en cuenta las necesidades de la imagen del interlocutor y también por cuidar su imagen (Albelda Marco y Barros García, 2013). Incluso, aunque es evidente que el contexto situacional puede variar la elección del lenguaje en cada caso, en los siguientes apartados se hará manifiesto que hay unas normas sociales o convenciones establecidas a priori, que se siguen en las conversaciones tanto en español como en euskera (por ejemplo, los interlocutores no establecen la misma relación entre familiares íntimos, con compañeros de trabajo, o con personas con un estatus social diferente). Además, la cultura peninsular es considerada a menudo como la cultura más orientada al individualismo de entre las culturas hispanas (Bravo, 1999; Fant, 1996; Hofstede, Hofstede y Minkov, 2010; Pinto y de Pablos-Ortega, 2014), con lo que la teoría de Brown y Levinson (1978, 1987) encaja perfectamente. Lo mismo ocurre con el País Vasco, que se considera como una de las regiones más individualistas de la península (Páez y Zubieta, 2004; Zlobina, 2004). Pero la razón más importante por la que se ha decantado por esta teoría en este trabajo es por creer que 
los conceptos de cortesía positiva y negativa, la distancia social (D) entre los interlocutores, el poder relativo $(\mathrm{P})$ entre el hablante y el oyente, y por último, el grado de imposiciones $(\mathrm{R})$, son absolutamente fundamentales para la interpretación que se desarrollará en el análisis de este trabajo acerca de los pronombres de segunda persona del singular en el español de la Península Ibérica y en euskera en el Capítulo V.

\section{La Deixis Personal y Social del Español Peninsular}

En el presente capítulo, se desarrollarán las principales nociones a tener en cuenta en relación con los usos establecidos de los dos pronombres de segunda persona del singular en el español peninsular: tú y usted. Estos dos pronombres son dos de las formas de tratamiento que existen en español y forman parte del fenómeno denominado deixis personal y social (Blas Arroyo, 2005b). La deixis personal, en primer lugar, establece que los pronombres de segunda

persona se refieren a uno o varios participantes en un contexto conversacional (Huang, 2007). A su vez, la deixis social señala el estatus social de los participantes en una interacción, e incluso, la relación que existe o se establece entre ellos dentro de cada contexto (Levinson, 1983), por ejemplo, si uno de los hablantes es superior al otro.

Algunos autores como Ardila (2003) utilizan los términos 'formal' e 'informal' para diferenciar los usos de los pronombres de segunda persona del singular del español. Otros autores utilizan los términos 'cortés' y 'descortés' para caracterizar tú y usted dependiendo del ámbito de uso y el contexto conversacional (Serrano, 2017). Se ofrecen así dos opciones pronominales a los hablantes de español para dirigirse a un receptor. A la hora de elegir uno de los dos pronombres en una conversación, el hablante tiene que considerar qué tipo de relación 
mantiene con su interlocutor, así como la distancia social que los separa, o por el contrario los une -lo que se denomina relación de poder relativo-(Carrasco Santana, 2002).

De la misma forma, se tienen en cuenta las implicaciones que acarrea el uso del pronombre tú o usted en la Península Ibérica. Es necesaria esta división ya que el uso de cada pronombre, dependiendo del contexto y de los hablantes, posibilita la creación de diferentes mensajes - por ejemplo, una petición puede ser más o menos directa dependiendo del pronombre que se utilice-, identidades -si un jefe y un empleado no se tratan de manera recíproca el primero adquiere un carácter superior-y, por tanto, relaciones interpersonales -podrán ser relaciones más o menos cercanas, íntimas o formales. De acuerdo con Lambert y Tucker (1976), cada forma de tratamiento en una lengua tiene diferentes significados para los participantes de una conversación y, de hecho, a través de las formas de tratamiento se pueden crear co-relaciones de edad, sexo, entorno, clase social, límites intergrupales o excluyentes, rol y estatus, y solidaridad entre otros.

Siguiendo las pautas de Brown y Levinson (1987), y en palabras de Blas Arroyo (1995), algunos de los factores que más influencia ejercen a la hora de elegir un pronombre u otro son las siguientes variables sociológicas: (i) la distancia social (D) entre los hablantes -p. ej., si son amigos o desconocidos-, (ii) el poder relativo (P) entre el hablante sobre el oyente -p. ej., si se trata de un jefe y un subordinado, o dos trabajadores al mismo nivel-, y (iii) el rango de imposición (R) que algunos intercambios comunicativos ejercen en una comunidad de habla -p. ej., si una petición puede suponer una imposición en el oyente. Por el contrario, Serrano (2017) sostiene que la elección de los pronombres no depende simple y llanamente de factores sociales, sino que también dependerá de otras funciones lingüísticas, así como de los objetivos comunicativos que cada hablante posea en cada situación particular. 
Por todo ello, este capítulo desarrollará los usos, significados, y creación de relaciones a través de cada uno de los pronombres de segunda persona del singular en el español de la Península Ibérica, comenzando con la descripción del pronombre tú, y más abajo, usted. TÚ

Una de las primeras características de este pronombre es que en general es considerado como el pronombre informal del español. Pero la cosa no queda en esa simplificación ya que este pronombre se vincula a su vez con términos como la solidaridad, familiaridad, confianza, e igualdad, pero no tanto con la cortesía (Blas Arroyo, 2005b). Sin embargo, los estudios previos han demostrado que el pronombre supuestamente informal, tú, ha pasado a utilizarse en ámbitos comunicativos en los que anteriormente estaban establecidos para el pronombre usted. Esto fue defendido por María Moliner ya en el año 1977, aunque de acuerdo con Soler-Espiauba (1994), la lengua española siempre ha tendido a tutear en comparación con otros idiomas, por haber abogado de forma significativa por el 'compadreo', entendido como el trato igualitario entre personas con diferencia de poder o estatus social.

Una de las fechas que se utilizan para a grosso modo establecer el comienzo del cambio de usted a tú es 1960 (de Jonge y Nieuwenhuijsen, 2012). Parece que hay unanimidad en concretar la época del inicio de la evolución de los pronombres de segunda persona del singular y efectivamente, autores como Carricaburo (1997), y Calderón Campos y Medina Morales (2010), atribuyen este cambio a hablantes jóvenes, la transición a la democracia, y una consecuente mayor libertad en los individuos, principalmente a partir del año 1975 con el fin de la dictadura franquista.

Ardila (2003) también establece el inicio del cambio en 1960, marcando las décadas de 1970 y 1980 como épocas principales de la evolución por acentuarse la transición de la dictadura 
franquista a la democracia actual. Por su parte, Carandell (1981) categorizaba de 'giro copernicano' la ampliación de tú producida durante el siglo XX y proporcionaba tres factores que causaron el mencionado cambio, en los que se comprueba que cualquier clase social empezó a utilizar este pronombre: (i) tú popular -producido por las clases sociales no redimidas-, (ii) tú aristocrático, y (iii) tú político -también llamado ‘tuteo a la romana', el cual podía producirse tanto por falangistas, como comunistas, e incluso monárquicos, entre otros. Entonces, era correcta la utilización de tú por parte de todas las clases sociales de aquel momento, demostrando así la expansión de esta forma de tratamiento. Algunos autores como Soler-Espiauba (1994) clasifican la ampliación de los ámbitos de uso de este pronombre como tú universal español-la posibilidad de utilizar tú en cualquier contexto-, argumentando que, en comparación con otras lenguas que se hablan en Europa, no se ha producido nada igual. Sin embargo, es igualmente cierto que en las lenguas europeas con doble pronombre de segunda persona del singular se ha percibido un cambio, aunque más lento y no tan drástico como en el español, en las formas de tratamiento relacionadas con la solidaridad y la reciprocidad (Blas Arroyo, 1995).

En la década de 1970, Marín (1972) presentó los principales usos que tenía el pronombre tú en aquel tiempo. En primer lugar, este autor argumentó que la función semántica del pronombre en cuestión era la de la igualdad, pero también superioridad - en casos en los que fuera expresado por parte de un superior a un inferior de manera no recíproca- (Marín, 1972). Así, durante este periodo, se apreciaba la presencia del pronombre tú de manera recíproca entre niños, adolescentes, y adultos con relación sanguínea, matrimonios, o amistades sin separación generacional (Solé, 1978). No obstante, aunque Marín ya notaba en 1972 que tú estaba acaparando los usos de usted entre los hablantes más jóvenes, puso en evidencia algunos contextos conversacionales en los que todavía se mantenía el uso del pronombre formal, por 
ejemplo, en casos en los que la diferencia o distancia era palpable, e incluso, en conversaciones entre padres e hijos en algunas zonas rurales.

Durante el siglo XX, el término 'intimidad' solía ser empleado para caracterizar la utilización de tú, pero autores como Soler-Espiauba (1994) lo rechazaban ofreciendo como ejemplo la presencia de este pronombre informal en conversaciones con amigos de amigos recientemente conocidos o presentados. Por ello, el término 'compartir' -por ejemplo, la generación y la amistad entre otras muchas posibles características o cosas-parece más adecuado para explicar los usos de tú (Soler-Espiauba, 1994).

Soler-Espiauba (1994) a través del análisis de cuatro novelas de la época (La hoja roja de Miguel Delibes de 1979; Amado Amo de Rosa Montero de 1988; Nebulosidad Variable de Carmen Martín Gaite de 1992; y Mañana en la batalla piensa en mí de Javier Marías de 1994) infirió que durante la última época del siglo XX era común presenciar un uso recíproco del pronombre informal en contextos como (i) relaciones familiares -excepto algunas zonas rurales-, y (ii) en el trabajo - tú entre iguales; pero con superiores existía la posibilidad de utilizar usted por parte del inferior y no del superior, aunque este último interlocutor podía introducir la posibilidad de utilizar tú por parte del subordinado. Por su parte, (iii) en la enseñanza se generalizó el uso recíproco de tú cerca de la década de los setenta, aunque en colegios privados no era tan asiduo, y en cambio, en la universidad, la edad y la forma de enseñanza de los profesores eran las causas de determinación para la selección de la forma de tratamiento (SolerEspiauba, 1994). Por último, (iv) en establecimientos públicos y comerciales -como tiendas de moda, tiendas para jóvenes, bares y cafeterías- era común el uso de tú, pero (v) no con el servicio doméstico - todavía no se atisbaba un uso recíproco del pronombre informal. 
Centrándose en el uso del pronombre informal de segunda persona del singular en la actualidad, de Jonge y Nieuwenhuijsen (2012) establecen que el pronombre tú se utiliza para dirigirse al destinatario de forma no convencional, haciendo así evidente la falta de marcadores de respeto o cortesía. No obstante, todo esto depende de si el uso del pronombre en cuestión es recíproco o no entre los hablantes en una situación determinada. Por tanto, un uso recíproco del pronombre tú presupone que los interlocutores son conocidos, pertenecen al mismo grupo, tienen contacto de manera frecuente, o son familiares; de lo contrario, un uso no recíproco del pronombre informal puede suponer la perturbación de una buena relación entre los interlocutores (de Jonge y Nieuwenhuijsen, 2012). Incluso, una supuesta asimetría en las formas de tratamiento puede llegar a ofender al oyente porque, mediante la selección de los pronombres de segunda persona del singular, se transmiten significados relacionados con la posición social y el grado de respeto social, entendidos tanto por el hablante como por el oyente o destinatario en cada contexto de forma particular (Ardila, 2003).

En la actualidad, el uso del pronombre informal tú es común en situaciones en las que no hay diferencias reseñables respecto a distancia social y edad (de Jonge y Nieuwenhuijsen, 2012). Estos ámbitos de uso pueden ser clasificados como categóricos y se observan cambios con épocas anteriores debido a que, por ejemplo, entre familiares con diferencia de edad-incluso de nietos a abuelos y viceversa- o en familias nucleares o extendidas, no hay tratamientos asimétricos, sino un uso extendido y recíproco de tú (Blas Arroyo, 2005a). Entre los jóvenes no familiares existe la misma situación con respecto a tú, independientemente del sexo de los interlocutores (Blas Arroyo, 2005a). En efecto, se suele emplear el pronombre informal de segunda persona del singular en algunas situaciones en las que en otras lenguas europeas se requiere el pronombre formal de segunda persona del singular (Ardila, 2003). Un ejemplo de esta 
diferencia entre el español y algunas de las lenguas europeas puede ser una conversación entre un nieto y un abuelo en el que, en el español de la Península Ibérica, ambos podrían utilizar tú de forma recíproca, y no así en el resto de Europa. De hecho, algunos autores como Carrasco Santana (2002) categorizan el tuteo en el español peninsular y en el presente siglo, como la norma social, por el hecho de existir la posibilidad de usar el pronombre tú incluso en situaciones formales, en las que los interlocutores no se conocen en profundidad, o en las que no hay lazos socio-afectivos. Todo esto demuestra que cada vez se apuesta más por la proximidad, la igualdad social y un sentido democrático en la sociedad actual. Este acercamiento o igualdad, no siempre se entiende como solidaridad entre los eruditos, ya que con la proximidad se puede perder la protección de uno mismo e incluso entrar en aspectos del interlocutor, lo cual puede amenazar la imagen social del hablante, e incluso del receptor, y que hace que los españoles sean categorizados -de una forma estereotipada- como 'maleducados' pero simpáticos (Carrasco Santana, 2002).

La presencia del pronombre de segunda persona del singular tú puede servir también como pronombre no referencial o impersonal (por ejemplo, en la frase 'Si un niño empieza a llorar, tú como adulto estás obligado a atenderle'). Se cree que la utilización de este tipo de pronombre impersonal se ha visto aumentado en los últimos tiempos en relación con el ya mencionado auge del pronombre tú frente a usted, aunque parece razonable pensar que la elección del pronombre de segunda persona del singular en su función impersonal está directamente relacionada con la forma referencial elegida en el resto de la conversación (LeónCastro Gómez, 2014). Según Llorente (1976) y Vila (1987), entre otros estudiosos, una de las funciones que puede realizar el tú no referencial es un uso refocalizador cuando adquiere a la figura del propio hablante como referente, facilitando de esta forma una mitigación de la 
subjetividad al no utilizar el pronombre de primera persona del singular, yo. Con todo, debe recordarse que el presente trabajo no se centrará en este tipo de funciones realizadas por el pronombre tú.

La elección correcta del pronombre de segunda persona recae mayormente en el hablante y en el destinatario, teniendo en cuenta factores como la diferencia de edad, la educación del propio hablante, incluso la ropa que lleva el destinatario en un momento dado, y el escenario en el que se produce la interacción verbal (Ardila, 2003). Autores como Blas Arroyo (2005a) declaran además que, en el presente siglo, es bastante común la interacción de conversaciones en las que la utilización del pronombre adecuado no sigue las normas sociales tradicionales y aceptables, sino que los hablantes se integran en una negociación del pronombre, primordialmente debido a los cambios sociales - como la igualdad social- que se han vivido en España en las últimas décadas. El uso de los pronombres en estos casos está plagado de incertidumbre por parte de los hablantes y, en consecuencia, el interlocutor suele dudar al comienzo de la conversación de qué pronombre escoger - por ejemplo, al dirigirse una persona joven a un amigo de su abuelo-(Blas Arroyo, 2005a). Otra característica de este tipo de uso es que la utilización de los pronombres puede evolucionar en una misma conversación dependiendo de los indicios de contextualización y también de los objetivos comunicativos (Blas Arroyo, 2005a).

En resumen, las principales utilidades del pronombre tú son la intimidad, informalidad, y la familiaridad, creando así supuestas relaciones cercanas, solidarias, e igualitarias. Blas Arroyo (2005b) razona que, con el cambio de uso de tú durante todos estos años, lo cual se interpreta como un avance para acabar con los prejuicios y jerarquías sociales, el tuteo se considera adecuado, e incluso en ocasiones cortés, en más y más situaciones. 


\section{USTED}

Al contrario que el pronombre tú, usted es considerado por lo general como el pronombre formal del español y, por tanto, tú y usted podrían ser categorizados, en un principio, como pronombres opuestos. Además de designar un carácter formal y cortés a usted (Blas Arroyo, 2005b), otros usos principales que tradicionalmente han sido relacionados con este pronombre son la expresión de distancia social y emocional (Solé, 1978). Esta distancia puede ser marcada tanto con un uso recíproco de la mencionada forma de tratamiento, así como con un uso no recíproco, tal y como se concreta más abajo. En este sentido, es importante recordar que como se ha mencionado en la sección anterior, varios de los ámbitos de uso de usted han sido relegados a tú durante los últimos tiempos, a partir de cerca del año 1960 (de Jonge y Nieuwenhuijsen, 2012; Marín, 1972; Soler-Espiauba, 1994). De hecho, a Blas Arroyo (1995) le sorprendió descubrir en su estudio que en los ámbitos en los que abundaban características formales, y por tanto en los que, en un primer lugar, se esperaría un uso abundante del pronombre usted, los porcentajes extraídos del empleo de tú y usted no eran tan diferentes: usted en $57.6 \%$ de los casos, mientras que tú en $42.4 \%$ de los casos.

Este sentido formal y cortés asignado a usted tiene sus orígenes en la historia de la lengua española, y es que el análisis del origen de usted es muy esclarecedor para considerar al pronombre de segunda persona del singular usted, como una forma de tratamiento formal. Usted es una forma variada y evolucionada de vuestra merced-forma de tratamiento cortés en el español clásico- y desde entonces acarrea la conjugación de la tercera persona del singular (Serrano, 2017). Es por eso que todavía hoy, aun siendo un pronombre de segunda persona del singular, se conjuga gramaticalmente como tercera persona del singular -como los otros pronombres de la misma categoría numérica, él y ella. Efectivamente, Serrano (2017) defiende 
que este pronombre debería ser descrito como pronombre de tercera persona del singular, implicando una forma indirecta de dirigirse al interlocutor, aunque al mismo tiempo reconoce que, es su carácter extradiscursivo lo que posibilita añadir usted al grupo de los pronombres de segunda persona del singular.

En esta línea cabe indicar que, aunque en la actualidad usted esté viendo disminuido sus ámbitos de uso, no fue siempre tan oscura la situación del pronombre formal en el español. Examinando el origen de usted en más profundidad, vuestra merced era en su origen un sintagma nominal que tenía la misma función que las formas de tratamiento, con un significado formal (de Jonge y Nieuwenhuijsen, 2012). A este respecto, Pharies (2015) ofrece una explicación en términos morfológicos y sintácticos y se puede resumir su aportación en que, a finales de la Edad Media, el pronombre que hasta ese momento tenía un significado cortés, este es uos, se fue erosionando de manera gradual hasta que se convirtió casi en sinónimo de tú. De esta forma, para poder seguir distinguiendo entre los usos familiares y formales, se abandonó uos como pronombre cortés y se extendió el uso de vuestra merced, aunque también de otros tratamientos honoríficos como señoría y merced (Pharies, 2015).

La historia muestra que fue a partir del siglo XVI cuando esta fórmula se gramaticalizó y se convirtió en un pronombre de tratamiento cortés (de Jonge y Nieuwenhuijsen, 2012). Concretamente, y aunque no se pueda encontrar unanimidad absoluta en datar la estandarización de usted, esta forma pronominal coexistía con otras variantes como uos, y Lapesa (2000) establece los siglos XVII y XVIII como los más significativos por su incremento en la difusión, mientras que de Jonge y Nieuwenhuijsen (2009) marcan el siglo XVII como el punto de inflexión de la conversión a la forma general de tratamiento frente a las otras variantes. Aquí se ha simplificado bastante la evolución de vuestra merced a usted, pero algunos estudiosos del 
español, como ejemplo, de Jonge y Nieuwenhuijsen (2012) y García-Godoy (2016), están conformes en exponer que es bastante complicado detectar la evolución de este pronombre por ser el resultado de varios cambios fonológicos. Sáez Rivera (2006) explica de forma breve la evolución, y consiguiente gramaticalización, de vuestra merced con los siguientes pasos y fechas: unessa merçed (1540), luego vuasted (1617) y vusted (1619), y finalmente sobresale usted (1620) en el siglo XIX.

Volviendo a las implicaciones extraídas del uso de usted, ya en el año 1978, Solé mencionaba que los significados mayores extraídos a través de la utilización de este pronombre eran los siguientes: formalidad, cortesía, deferencia, distancia social o psicológica, y respeto. Añadía, sin embargo, que, en la mayoría de las conversaciones, usted podría ser apreciado como una forma convencional no marcada en aquellos casos en los que se encontraran interlocutores desconocidos o que se conocieran de forma casual (Solé, 1978). Blas Arroyo (1995) comprobó su uso en la Comunidad Valenciana alegando que en las conversaciones en las que predominaban características como la deferencia y el respeto -denominado por él como 'reverencia'-, así como la falta de familiaridad, imperaba el uso de usted.

Los significados listados en el párrafo anterior resumen gran parte de las interpretaciones de usted, si bien, en un análisis hay que tener en cuenta la reciprocidad o no del pronombre. Alonso-Cortés (1999) está de acuerdo en definir el uso recíproco de usted como marcador de respeto y distancia entre los interlocutores. Por otro lado, es importante también la consideración del establecimiento de una relación social solidaria a través del uso recíproco de este pronombre formal, relación que a menudo se vincula simplemente con el uso recíproco de tú (de Jonge y Niuewenhuijsen, 2012). Es común, sin embargo, encontrar en las conversaciones en español un trato no recíproco, por ejemplo, entre un jefe y un empleado, en los que el primero es 
considerado superior y el segundo subordinado o inferior. Carricaburo (1997) indica que, en los tratos no recíprocos, el superior emplea tú y es, por tanto, quien tiene el poder en la relación puede ser causado por una mayor autoridad, prestigio, o más edad-, y el hablante que utiliza usted implica que tiene menos poder que su interlocutor.

En consecuencia, el punto fundamental del pronombre central de esta parte del capítulo es que al ser un pronombre que emite el significado de un tratamiento cortés entre los interlocutores, el cometido principal de usted suele ser el de transmitir respeto al destinatario, marcando distancia o un reconocimiento explícito de subordinación -a veces también de superioridad- e incluso protección de la imagen del hablante; con todo esto se abstiene de transmitir un sentido de igualdad social (Carrasco Santana, 2002). Es decir, de acuerdo con Brown y Levinson (1987), los pronombres como usted (V) forman parte de la cortesía negativa. Esta idea general de distancia, cortesía, y desigualdad causan evidentemente algunas consecuencias en el habla cotidiana. Como estas ideas transmitidas por usted forman parte de las normas culturales, su uso se establece en la comunidad y pasa a ser rutinario y automático en las conversaciones - por ejemplo, la mayoría de los diálogos entre personas desconocidas en la Península Ibérica están acaparadas por la presencia de usted, lo cual se suele producir de forma automática e inconsciente-(Blas Arroyo, 2005b). Pero el escenario puede condicionar el uso de los pronombres entre desconocidos ya que en algunos estudios sobre las prestaciones de servicio se observó que tú predominaba en ese contexto, a pesar de que los participantes fueran desconocidos (Placencia, 2005).

Un uso totalmente separado al de los hasta ahora mencionados en esta parte del presente capítulo, es el de usted impersonal (por ejemplo, la frase 'Haga usted lo que sepa' en un contexto en el que hay varias personas actuando diferentes disciplinas artísticas en un mismo ámbito y a la 
vez), similar a tú impersonal. El uso de usted impersonal, siguiendo las investigaciones de deMello (2000), se produce casi de forma única en las interacciones en las que la forma de tratamiento -en su función referencial- es usted, aunque también encuentra excepciones en conversaciones en las que la forma de tratamiento utilizada es el tuteo (citado en León-Castro Gómez, 2014). Este usted impersonal puede tener la función de refocalizador al referirse al hablante de la conversación, lo cual resulta en una expresión del significado de una forma más objetiva, abstracta, y en efecto, impersonal (León-Castro Gómez, 2014).

Volviendo a las implicaciones en su uso referencial, el empleo de usted también puede no resultar en un trato cortés sino ser interpretado como una amenaza a la imagen social del receptor. En el siglo actual, como se ha extendido hasta tal punto la presencia de tú, hay situaciones en las que, aunque exista una distancia social o de poder entre los participantes de la conversación, la persona que mantiene el poder o superioridad aboga por el uso de tú en lugar de usted. A este respecto, Carrasco Santana (2002) desarrolla que un hablante puede amenazar su propia imagen al referirse al destinatario con usted, ofreciendo como caso una conversación con una persona mayor: el emisor empieza tratando al interlocutor con usted, pero el destinatario le contesta con 'no me trates de usted que no soy tan viejo' (p. 44).

Así pues, los significados más notables que se extraen por medio de las conversaciones con presencia del pronombre de segunda persona del singular usted, son la cortesía, distancia social o de poder, respeto, y protección de la imagen social del propio hablante frente al emisor. A pesar de ello, los contextos particulares y la utilización del pronombre de una forma recíproca o no, podrá cambiar los significados que se puedan extraer del empleo del pronombre formal del español. Por ello, es necesario el análisis que se desarrollará en el Capítulo V, para comprobar su 
uso en el siglo XXI de una forma contextualizada, para así poder concluir la creación de relaciones interpersonales a través de usted.

Finalmente, relacionando todo lo expuesto en esta sección sobre tú y usted en el español peninsular, con lo presentado en la sección anterior acerca de la teoría de la cortesía de Brown y Levinson $(1978,1987)$ sería correcto relacionar cada pronombre con un tipo de cortesía en concreto. De hecho, Brown y Levinson (1987) argumentan que las formas de tratamiento, y por ende los pronombres de segunda persona del singular, son formas gramaticalizadas que pueden servir para minimizar los actos de amenaza hacia la imagen ('face') de los oyentes. Todo esto ha sido mencionado anteriormente, pero es importante destacar como punto final de esta sección la relación del pronombre tú $(\mathrm{T})$ con la cortesía positiva, y por su parte, la conexión de usted (V) con la teoría de la cortesía negativa, ambos siendo fruto de la teoría de la cortesía de Brown y Levinson (1987) (Blas Arroyo, 1994, 1995, 2005a, 2005b).

\section{La Deixis Personal y Social del Euskera}

De una forma similar al del capítulo anterior -dedicado a los usos establecidos de los pronombres de segunda persona del singular en el español de la Península Ibérica- este capítulo también tratará de esclarecer y diferenciar los ámbitos de uso, los significados y las implicaciones en el empleo de las formas de segunda persona del singular $-z u$ e $h i-$ en el euskera occidental -las provincias de Bizkaia, Gipuzkoa, y Araba. La razón por la cual no se estudia otra variedad del euskera - como la de Navarra o el País Vasco francés- es por la falta de uniformidad de sus variedades en relación a las variedades del euskera que se dan en Bizkaia, Gipuzkoa, y Araba, esto es, por razones de simplicidad. Aunque en la actualidad existan dos pronombres de segunda persona del singular, el sistema original ofrecía solo uno para singular $-h i-$ y uno para 
el plural -zu- (Zubiri y Zubiri, 2000). Con el tiempo, $h i$ fue perdiendo fuerza, $z u$ tomó su lugar, y se creó otro pronombre para la segunda persona del plural: zuek $(z u+$ marca del plural) (Zubiri y Zubiri, 2000).

Antes de profundizar en el tema es importante aclarar que el euskera tiene dos registros principales $^{1}$ : hika-registro familiar-y zuka-regístro estándar y a veces formal- (de Rijk, 2008; Wolpert, Mancini y Caffarra, 2017). Dentro del primer registro, el pronombre de segunda persona del singular es $h i$, el cual, obviamente, siempre se refiere al oyente y se caracteriza principalmente por ser utilizado en contextos familiares o entre amigos y por no encontrar su presencia en todas las variedades del euskera (Laka, 1996). En el segundo registro, el pronombre de segunda persona del singular que se utiliza es $z u$ : siempre se refiere al destinatario, a diferencia de $h i$, se produce en todas las variedades existentes del euskera, y ofrece la posibilidad de utilizarlo en todos los contextos posibles (Laka, 1996).

De acuerdo con de Rijk (1991), desde el siglo XVII hasta comienzos de la última década del siglo XX, se hicieron pocas aportaciones en la literatura gramatical respecto a cómo funcionaban las formas de tratamiento en euskera. No obstante, tradicionalmente, una de las formas de constatar la diferencia entre $h i$ y $z u$ ha sido mediante el uso de los términos 'formal' e

\footnotetext{
${ }^{1}$ Existen otros registros en algunas variedades del euskera, los cuales pueden incluir otro pronombre además de los ya referidos. Uno de ellos es berori, un pronombre demostrativo que se utiliza como pronombre de segunda persona del singular con valor de cortesía (Laka, 1996) y que se forma mediante la unión de ber- 'mismo' y hori 'eso' (Alberdi, 1995; de Rijk, 1991, 2008; Trask, 2003; Zubiri y Zubiri, 2000). Por otro lado, algunas variedades dialectales del este del País Vasco ofrecen una posibilidad más dentro de los pronombres de segunda persona del singular: $x u$-forma palatalizada de $z u$ y pronombre intermedio entre $h i$ y $z u$ (Alberdi, 1995; Trask, 1997, 2003). Pero estos pronombres del euskera, berori y $x u$, no merecen más atención, por el hecho de no ser utilizados en el análisis del presente trabajo debido a que berori se suele utilizar casi exclusivamente en algunos contextos formales como instancias, solicitudes y formularios formales (Euskaltzaindia, 1985; Zubiri y Zubiri, 2000), y porque $x u$ no se produce en las provincias (Bizkaia, Gipuzkoa, y Araba) que se han seleccionado para este análisis (Alberdi, 1995).
} 
'informal'. En el año 1988, Saltarelli caracterizaba a zu como pronombre más formal o respetuoso -se empleaba al dirigirse a padres, personas mayores, desconocidos, y cónyugespero estos significados estaban ya en bastante desuso y así, se pueden categorizar ambos pronombres de la siguiente forma: $z u$ se utiliza de forma más o menos exclusiva en las zonas urbanas, mientras que $h i$ se utiliza de manera más o menos exclusiva en áreas rurales. De Rijk (2008) está también de acuerdo en establecer esta diferenciación entre las zonas urbanas y rurales.

Por el contrario, de Rijk (1991) no está conforme con utilizar los términos 'formal' e 'informal' para señalar a los dos pronombres de segunda persona del singular en euskera por llevar a la confusa esperanza de poder establecer una similitud con las lenguas romances vecinas. Él propuso una perspectiva en la que $z u$ es el pronombre normal, no marcado pragmáticamente, mientras que $h i$ es su sustituto marcado, indicador de solidaridad en aquellos dialectos con presencia de este pronombre, definido por las realidades sociales de la cultura local vasca (Amorrortu, 2003; de Rijk, 1991, 2008; Trask, 1997). Esta introducción del término 'pragmáticamente no marcado' está causado sobre todo porque una diferenciación de $h i$ y zu en términos de solidaridad y respeto hace a los analistas comparar estos pronombres de segunda persona del singular con los pronombres de sus lenguas vecinas, en un intento equivocado (de Rijk, 1991, 2008). Pero para entender mejor esta diferenciación, es preciso citar a Alberdi (1991) y la razón fundamental que él ofrece a este respecto. Alberdi (1991) está de acuerdo en esta segunda opción de categorización que se ha mencionado con las palabras de de Rijk (1991, 2008) porque, a diferencia de otras lenguas vecinas del euskera como el español o el francés, en caso de duda, la utilización de $z u$ siempre será acertada. Esta afirmación va en detrimento de la 
presencia de $h i$ en las conversaciones en euskera, porque en efecto, en las conversaciones en la sociedad vasca, $z u$ es la ganadora (Alberdi, 1991, 1994).

Si a modo de introducción se compara el uso de $h i$ con el tuteo en el español peninsular, la utilización del pronombre vasco está más restringida que el del español (Alberdi, 1995). De hecho, allá por el siglo XVIII, Larramendi $(1728,1729)$ ya mencionaba la falta de conexión entre la utilización del euskera y del español, defendiendo que $z u$ es un pronombre intermedio en cuanto a los tratamientos asociados con los pronombres del español tú y usted (citado en Alberdi, 1995). Sin embargo, otros autores como de Rijk (1991) comparan la diferencia entre $h i$ y zu con la distinción establecida con los pronombres en español tú y usted, o los pronombres franceses tu y vous. En cualquier caso, en lenguas europeas como el francés, italiano, alemán, español e inglés entre otros, se ha favorecido la igualdad a la diferenciación y en la actualidad raramente se encuentran relaciones asimétricas a través de los pronombres respectivos en cada lengua, aumentando a su vez, la utilización del pronombre T, no así en euskera -el tratamiento recíproco de $h i$ es una opción especial y marcada principalmente a las limitaciones establecidas por algunas relaciones familiares y de amistad, utilizando siempre ante la duda (V-V) $z u-$ (Alberdi, 1994).

Parece que los ámbitos de uso relacionados con el pronombre $h i$ durante el siglo XVI y en la actualidad no difieren tanto entre sí, ya que los factores decisivos para considerar la forma de tratamiento durante aquel tiempo y en la actualidad son probablemente los mismos: el sexo, la edad y el tipo de relación (Alberdi, 1995). Lo que sí ha cambiado notablemente desde aquel siglo es el número de uso de $h i$, sobre todo, el que se produce entre las mujeres, consecuentemente causando que en muchos dialectos del euskera la conjugación del alocutivo ${ }^{2}$ femenino de $h i$ sea muy escasa y esté en peligro de perderse (Alberdi, 1995). Incluso, en algunas regiones del País

\footnotetext{
${ }^{2}$ Las formas alocutivas son aquellas en las que el verbo declinado conjuga con el destinatario en persona y género, y el género no es un argumento seleccionado por el verbo (Amorrortu, 2003).
} 
Vasco hi está en completo desuso, dejando en consecuencia a $z u$ como única forma de segunda persona del singular (de Rijk, 1991; Euskaltzaindia, 1985; Saltarelli, 1988). Es revelador también que los tratamientos en euskera dependan a menudo de la tradición, siguiendo el principio de que una vez empezado de una forma, hay que seguir de esa manera durante todos los años que conoces a una persona (Alberdi, 1994).

Si se compara esta evolución de $h i$ a favor de $z u$, con el cambio de usted a tú en el español peninsular, se puede comprobar que son transformaciones completamente opuestas: en euskera parece haberse favorecido el llamado pronombre 'formal' $z u$, haciendo que se extienda a contextos más 'informales', mientras que en español se ha favorecido el pronombre 'informal' tú frente al descenso de la utilización del 'formal' usted (Alberdi, 1994). Aun así, seguramente no haya habido muchos cambios en las formas de tratamiento en euskera durante los últimos quinientos años (Alberdi, 1995). Esta aseveración se vuelve a oponer al cambio del español peninsular, ya que la evolución en dicha lengua parte sobre todo a partir del año 1960, tal y como se argumentó en el capítulo previo.

Con todo, el actual capítulo desarrollará en profundidad los usos y las implicaciones relacionados con $h i$ y $z u$ en euskera como base para el análisis en el Capítulo V. En este capítulo habrá que tener en mente que la situación del euskera en cuanto a los tratamientos con los pronombres de segunda persona del singular es la siguiente: la tendencia del euskera es al tratamiento igualitario o simétrico (tanto con $\mathrm{V}-\mathrm{V}$ o T-T), aunque en el ámbito familiar el tratamiento no recíproco (T-V) esté asentado en los dialectos con presencia de hi (Alberdi, 1994). 


\section{HI}

Tal y como se ha mencionado en la introducción de este capítulo, el uso recíproco del pronombre $h i$ marca la existencia de una relación estrecha o familiar entre los interlocutores (Wolpert, Mancini y Caffarra, 2017). Así las cosas, no parece que sea una tarea fácil el hecho de extraer generalizaciones sobre $h i$ : indica intimidad cuando se utiliza entre amigos, se utiliza también para dirigirse a personas de mismo o similar estatus social (p. ej., hermanos o amigos de la misma edad), y personas de estatus social más baja (p. ej., niños o hermanos más jóvenes), para insultar a un interlocutor, o para chismorrear sobre alguien que no está presente en la conversación (Echeverria, 2003). Además, es destacable que los hombres utilizan más hika que las mujeres -incluso, las mujeres se tratan menos en hika incluso entre ellas- y que en los pueblos del interior del País Vasco se utiliza más que en las localidades costeras (Amorrortu, 2003).

Como en muchas áreas del País Vasco y en sus respectivos dialectos no existe la posibilidad de utilizar $h i$ en la actualidad, resulta complicado estudiar sus utilizaciones en zonas urbanas porque mayormente es una característica lingüística de pueblos rurales y pequeños, aunque es igualmente cierto que los hablantes de euskera que no emplean $h i$, conocen su significado social al igual que el de $z u$ (Echeverria, 2003). Según Alberdi (1991), algunas de las causas posibles del declive de $h i$, y del más que probable remplazamiento por parte de $z u$, son las siguientes: (i) la salud del euskera - por lo menos en la última década del siglo XX- no era muy halagüeña y por tanto, si la fuerza de la lengua fuera más, el pronombre informal $h i$ tendría también más probabilidad de conservación; (ii) la abundante morfología del hika generado por su alocutivismo complica su aprendizaje para aquellos que no lo han adquirido desde pequeños; (iii) la transmisión de padres a hijos ha sido a veces interrumpida por haberle designado 
implicaciones despectivas al registro -se profundiza más en el siguiente párrafo-; (iv) en la tradición literaria vasca se han creado pocas obras de teatro y en ellos se ha trabajado sobre todo el registro formal; (v) la educación escolar tampoco contribuye a la mejoría de hi por existir otros ámbitos más primordiales; y finalmente, (vi) Euskal Irrati Telebista (Radio-Televisión Pública Vasca) ha hecho esfuerzos en reforzar el registro hika topándose con unos límites -como la necesidad de utilización del registro estándar- en su causa.

Además, se desconoce cuándo, quién y por qué se le atribuyó mala fama al registro hika en muchas partes del País Vasco, teniendo consecuentemente connotaciones peyorativas para muchos de los hablantes -habla de los gitanos y campesinos, habla dura, robusta y bruta entre otros adjetivos- (Alberdi, 1991; Euskaltzaindia, 1985), aunque en los últimos años se ha reavivado y ha cogido más fuerza (Euskaltzaindia, 1985; Zubiri y Zubiri, 2000). No se dan las razones de esta recuperación, pero probablemente, la importancia que durante los últimos años se le ha dado a la relación entre identidad y lengua, y el aumento de conciencia de la mala situación por la que pasó el euskera siendo una lengua minoritaria, hayan causado efectos en hi. También ha sido descrito como algo 'muy muy vasco' y solo característico de algunos hablantes nativos especialmente los que viven en pueblos pequeños, y más concretamente en caseríos- pero no en sentido peyorativo (Echeverria, 2003).

En esta dirección, se percibe que los factores sociales juegan un papel fundamental en la evolución de hi (de Rijk, 1991). Aquí se propone que habría que mencionar también la influencia de la dictadura franquista en el País Vasco. Durante los años de la dictadura (1939-1975), el dictador Franco prohibió la utilización de cualquier lengua que no fuera español, creando de esta forma consecuencias directas en lenguas como el euskera, el catalán y el gallego. Así, por ejemplo, muchos padres no tuvieron la oportunidad de transmitir su lengua materna a sus hijos, y 
como $h i$ se transmite tradicionalmente de forma oral en lugar de en las escuelas, la prohibición de hablar en euskera pudo tener una consecuencia más que directa en él. Por otro lado, se ha mencionado anteriormente que la morfología verbal de hika es muy complicada, lo cual habrá causado estragos en el aprendizaje del mismo, siendo esta una causa importante para la pérdida de este registro. Por tanto, se defiende aquí que este registro no se está debilitando solo por cuestiones de diferenciación social como en el español peninsular, sino que ha sido la causa de un conjunto de factores externos y sociales. A pesar de este debilitamiento, la dimensión social también ha servido para reforzar y valorar el uso de hika: es muy utilizado por 'radicales vascos' como una forma de rechazar las jerarquías sociales que han dominado al País Vasco -incluyendo gran parte de la cultura política nacionalista- y se asocia con la militancia nacionalista vasca -la mayoría son hombres- (Echeverria, 2003). En efecto, hi se asocia con lo 'auténtico' vasco actividades como pilota ${ }^{3}$, o bertsolaritza ${ }^{4}$ - y el habla de los hombres (Amorrortu, 2003).

Alberdi (1991, págs. 434-438) ofreció una descripción pormenorizada del uso del registro hika con el consecuente pronombre $h i$, basándose en once variables, que todavía sirve para un análisis realizado en la actualidad:

- Tema: aunque esta no sea una variable muy importante en euskera, algunos hablantes utilizan hika para hacer bromas y no tanto para cuestiones más serias como negocios y reuniones.

- Contexto: esta variable es más significativa. Por ejemplo, hika es apropiado para festejos, pero no para funerales. Tampoco es lo mismo estar solo que delante de la

\footnotetext{
${ }^{3}$ Es un deporte tradicional del País Vasco, se juega en un frontón con una pelota, y se requieren al menos dos jugadores.

${ }^{4}$ Es un acto muy popular en el País Vasco que consiste en cantar en verso de forma improvisada basándose en las melodías de canciones conocidas en euskera. Las personas que cantan de esta forma suelen actuar en plazas de pueblo, en comidas populares, o en concursos organizados.
} 
gente, con lo que se utilizaría en el primero de los contextos y probablemente no en el segundo.

- Edad: esta variable es fundamental, siendo evidente y más probable que un vasco se dirija a una persona de edad similar con $h i$, y no tanto a una persona mayor.

- Generación: algunos vascos utilizan hi para dirigirse a personas con un margen de cuatro o cinco años más o menos, mientras que otros toman como referencia una generación entera.

- Sexo: es una de las variables más básicas. Es más fácil que exista un trato simétrico de $h i$ entre personas del mismo sexo, y dentro de este factor, es más común entre hombres que entre mujeres.

- Parentesco: por ejemplo, es más típico que la conversación se mantenga con $h i$ entre hermanos de edad parecida, que entre primos de edad similar.

- Dialecto: a menudo, la elección del registro de una persona se adapta al modo de hablar o las costumbres del interlocutor. De esta forma, por ejemplo, para algunos hablantes que practican hika, este registro se restringe a utilizarlo solamente con personas que conocen de toda la vida.

- Camaradería: no parece que esta variable en euskera sea muy importante.

- Poder: en el ámbito de la familia, los hijos nunca se dirigen a sus padres, ni a familiares mayores, con $h i$-salvo alguna excepción-dando lugar así a un trato asimétrico. En el contexto laboral, nunca se utiliza hi para dirigirse al jefe o superior.

- Unión psicológica: para muchas de las personas que emplean el registro hika, es característico de relaciones de confianza: registro de entre amigos. 
- Carácter y apariencia: parece que a una persona con carácter cómico le viene mejor hika que al que tiene un carácter más serio.

Si se comparan estas variables, con los usos asignados a hi durante el siglo XXI, se puede demostrar que no ha habido un gran cambio en las restricciones. Por ejemplo, Trask (2003) resumió los usos establecidos de $h i$ de la siguiente forma: (i) su uso suele ser obligatorio entre hermanos, y entre amigos íntimos del mismo sexo y de parecida edad, particularmente aquellos que han crecido juntos; (ii) el pronombre $h i$ es opcional a la hora de dirigirse a niños, al hacer burlas, maldiciones, o abusos -a personas o animales-; (iii) no se suele utilizar al dirigirse a una persona adulta del sexo contrario - excepto entre hermanos-, ni siquiera al cónyuge, al dirigirse a una persona notablemente mayor -ni a un padre-, o a una persona de estatus superior.

Al igual que los pronombres del español implican algunos significados -por ejemplo, tú puede indicar intimidad y usted deferencia-, lo mismo ocurre en euskera con hi. Echeverria (2003) argumenta que $h i$ señala algunos significados sociales -entre otros, autenticidad étnica y espontaneidad- al igual que señala algunas actividades sociales, por ejemplo, el levantamiento de piedras - deporte tradicional de la cultura vasca-, la mayoría relacionados principalmente con hombres, lo cual consecuentemente crea una relación icónica entre la auténtica identidad vasca y la masculinidad.

La mayor particularidad de hika reside en que como consecuencia de su obligatoria concordancia alocutiva -la desinencia del verbo auxiliar concuerda con el destinatario noargumental-, existen dos variedades de concordancia alocutiva para el género del destinatario: teniendo en cuenta la complicación de la morfología verbal del euskera, la forma verbal masculina en hika generalmente incluye $-k /-a$ - y la forma femenina -n/-na- (Wolpert, Mancini y Caffarra, 2017). Efectivamente, esta cuestión es curiosa porque más allá de la concordancia 
alocutiva, el euskera no tiene morfología nominal para marcar los pronombres con el género (Amorrortu, 2003; Echeverria, 2003; Wolpert, Mancini y Caffarra, 2017). Explicado de otra forma, cuando el destinatario es el sujeto de un verbo intransitivo (caso absolutivo), el verbo no acarrea la concordancia de género; pero, cuando el destinatario es el sujeto de un verbo transitivo (caso ergativo), o cuando es el objeto indirecto (caso dativo), el verbo auxiliar marca el género del destinatario: - $n$ para femenino -por ejemplo 'dun' en lan egin dun, traducido como 'has trabajado'-, y -k para masculino - por ejemplo ‘duk' en lan egin $d u k$, traducido como 'has trabajado' (Echeverria, 2003). Lo que ocurre es que el correspondiente pronombre de segunda persona, $h i$, es invariable en cuanto al género (Amorrortu, 2003). Además, existen dos nombres correspondientes para referirse al habla de cada género dentro del registro hika: toka -la forma del hika con destinatario masculino-y noka -la forma del hika con destinatario femenino(Amorrortu, 2003).

Tratando de establecer una conexión entre el euskera y sus lenguas vecinas, Echeverria (2003) ofrece varias razones para defender que $h i$ no se puede equiparar a otros pronombres T (pronombres familiares): (i) se puede emplear $h i$ en situaciones no necesariamente paralelas con otros pronombres $\mathrm{T}$-por ejemplo, al dirigirse a un objeto inanimado, al hablar al cuerpo de uno mismo, o al hablarse a sí mismo-; y (ii) a diferencia de sus lenguas vecinas, es muy usual el uso asimétrico de los pronombres -por ejemplo, en las familias que utilizan $h i$, es muy común encontrar conversaciones reglamentadas por el uso asimétrico de $h i$ y zu entre padres e hijos, y $z u$ recíproco entre parejas- aunque en ámbitos como el trabajo es habitual tener conversaciones con pronombres recíprocos (Echeverria, 2003).

Si por un momento se centra la atención en la forma del plural de los pronombres de segunda persona, la diferenciación que existe entre $h i$ y zu en el singular, no es tal en el plural 
(Alberdi, 1995). De hecho, la oposición de estos dos pronombres se neutraliza en el plural ya que, existe un único pronombre de segunda persona del plural: zuek (Alberdi, 1994). La única otra forma que puede decirse que existe como pronombre de segunda persona del plural es berorrek, el cual es extremadamente formal y arcaico en la mayoría de las variedades (Amorrortu, 2003).

Como resultado, las ideas principales que se extraen del uso de $h i$ en los registros del euskera en los que se produce dicha forma pronominal, son intimidad entre amigos y familiares como hermanos del mismo sexo y de la misma edad, pero de distancia por un trato asimétrico hacia personas de clase social más baja o familiares del mismo sexo, pero más jóvenes, por ejemplo, de padres a hijos. Entonces, según Echeverria (2001, 2003, 2010) y Haddican (2003, 2007), el uso de hika está tradicionalmente y socialmente restringido, es utilizado mayormente por hombres y personas mayores, y gran parte de los hablantes de euskera no saben cómo utilizar la complicada morfología verbal que requiere este registro para la concordancia del alocutivo.

\section{$\mathbf{Z U}$}

En cuanto al pronombre de segunda persona del singular $z u$, su utilización es correcta en todos aquellos casos en los que el uso de $h i$ no es apropiado. Ya se ha mencionado en este capítulo que $z u$ en su origen no era un pronombre de segunda persona del singular, sino que era un pronombre plural, pero es importante ahondar más en este punto. Desde hace varios siglos hay dos pronombres de segunda persona del singular, pero en el sistema original había una sola forma pronominal en singular $-h i-\mathrm{y}$ una en plural $-z u-$ (Zubiri y Zubiri, 2000). Se cree que, con la influencia de las lenguas romances vecinas, se empezó a utilizar $z u$ como pronombre singular de respeto (Zubiri y Zubiri, 2000). Como se ha visto en la sección anterior, el uso de $h i$ se fue debilitando, reforzando así el uso de $z u$ (Zubiri y Zubiri, 2000). De hecho, aun hoy en día, el 
verbo que acompaña al pronombre $z u$ se conjuga en plural (Trask, 2003). Para llenar el hueco del pronombre de segunda persona del plural se creó otro pronombre: zuek $(z u+$ marca del plural $)$ y la creación de la nueva forma plural tiene doble concordancia del plural (Trask, 2003). Todo esto hace que, $z u$ sea clasificado a menudo con en el grupo de los pronombres plurales ya que todavía el verbo que lo acompaña se conjuga en segunda persona del plural (Alberdi, 1995;

Euskaltzaindia, 1985; Trask, 2003). Por tanto, originalmente $z u$ era un pronombre plural, pero empezó a ser utilizado como pronombre de respeto de segunda persona del singular, expandiéndose con el tiempo a todas las variedades del euskera y quitando el sitio a hi (Zubiri y Zubiri, 2000).

La razón del cambio del plural a singular es atribuida generalmente a la influencia causada por las lenguas romances vecinas del euskera (Alberdi, 1995). Es curioso que ninguno de los artículos revisados para este trabajo haga referencia alguna a la posible fecha de este cambio y, en este sentido, Alberdi (1995) lo calificó como una tarea imposible, dado que desde los primeros documentos escritos el pronombre $z u$ aparece exclusivamente con el valor de pronombre respetuoso de la segunda persona del singular. Entonces, en su lugar, se creó la forma zuek como pronombre de segunda persona del plural -para completar el hueco que dejó zu al ser convertido en pronombre de segunda persona del singular-tal y como se ha referido en el apartado anterior (Alberdi, 1995; Euskaltzaindia, 1985; Zubiri y Zubiri, 2000). La creación de este pronombre se produjo con la combinación de $z u$ y el sufijo del plural (Alberdi, 1995; de Rijk, 2008; Trask, 1997), y se produce en todas las variedades del euskera (de Rijk, 2008).

La utilización de esta forma pronominal es la más común en la sociedad actual en el País Vasco y, en efecto, en 1991 Alberdi ya preveía una más que probable pérdida de $h i$ a favor de $z u$ : si alguien duda de qué pronombre utilizar en una conversación, la elección de $z u$ siempre será 
correcta $\mathrm{y}$, de hecho, es el pronombre de segunda persona del singular más utilizado - de forma recíproca- en las interacciones verbales. Incluso, para la mayoría de los hablantes de euskera, es la única forma de segunda persona del singular que utilizan (Euskaltzaindia, 1985). Esto significa que $z u k a$ es el registro estándar para gran parte de las interacciones que se producen en euskera (Wolpert, Mancini y Caffarra, 2017). En la enseñanza también se utiliza casi de forma única el pronombre zu y los libros pedagógicos del euskera lo suelen presentar, frente a $h i$ en los dialectos en los que este pronombre también se produce, como la forma cultivada, utilizada por personas educadas, y marca de respeto que debería utilizarse, por ejemplo, para dirigirse a personas de edad superior (Echeverria, 2003).

De esta forma, lo más importante a tener en cuenta para el análisis que se hará a continuación en el Capítulo V, es que zu es la forma más utilizada en todas las variedades del euskera, y que en aquellos en los que se pueden utilizar $h i \mathrm{y} z u$, la segunda forma es una marca de cortesía, respeto y distancia. Sin embargo, también adquiere el valor de pronombre pragmáticamente no marcado en diferentes contextos. Además, en caso de duda, $z u$ siempre será la elección más correcta.

\section{Objetivo y Preguntas de Investigación}

Llegados a este punto, debería concretarse el objetivo con el que fue iniciado, y a su vez llevado a cabo, este análisis. La meta principal, por tanto, de este trabajo es hacer una comparación sincrónica dentro del marco de la pragmática intercultural para comparar la creación de relaciones personales en español peninsular y en euskera mediante el uso de las formas de tratamiento. Más concretamente, las formas de tratamiento elegidas aquí son los pronombres de segunda persona del singular del español -tú y usted-y euskera - hi y zu-. Tal y 
como se ha desarrollado en este capítulo, el uso de estas formas de tratamiento depende de factores como la distancia, poder e imposición y, por consiguiente, el tipo de relación que existe entre los participantes y el género de estos. Es decir, el presente estudio tiene como objetivo contrastar dos lenguas que a lo largo de los siglos han estado en constante contacto para delimitar si la creación de relaciones interpersonales con el uso de sus correspondientes pronombres de segunda persona del singular, es de alguna manera similar o diferente. Ya se ha mencionado, además, que siendo el español peninsular y el euskera dos lenguas en permanente contacto, han tenido una evolución opuesta en cuanto al uso de sus pronombres de segunda persona del singular. Es por eso que el presente análisis pretende dar respuesta a las siguientes preguntas de investigación, con la intención de aportar claridad en la relación entre el español peninsular y el euskera:

1. ¿En qué situaciones y contextos se utilizan los pronombres de segunda persona del singular en español y en euskera?

2. ¿Qué significados implícitos señalan estos pronombres y qué relaciones interpersonales se establecen a través de ellos, con la interpretación de la teoría de la cortesía de Brown y Levinson $(1978,1987)$ ? ¿Qué factores sociales contribuyen a los usos de estos pronombres?

3. ¿En qué se parecen y en qué se diferencian los usos y los significados de los pronombres de segunda persona del singular en español y en euskera? 


\section{CAPÍTULO III: METODOLOGÍA}

El análisis en los siguientes capítulos tendrá como objetivo comparar los usos de los pronombres de segunda persona del singular en español y euskera. El análisis de la variación de los pronombres tú y usted en el español de la Península Ibérica en el siglo XXI se basará en la revisión de estudios empíricos anteriores (p. ej. Montero Curiel [2011] en Extremadura; Sampedro Mella [2016] abarcando el español centro-norteño; Pedroviejo Esteruelas [2006] en Valladolid; Sanromán Vilas [2010] en Vigo y en Madrid). La razón por la cual se ha decidido basar el análisis en la literatura previa en lugar de realizar un estudio a través del análisis de conversaciones espontáneas entre hispanohablantes o la observación de datos presentados en diferentes corpora, es porque se ha escrito de forma amplia en cuanto a la utilización de los pronombres de segunda persona del singular en el español peninsular y la creación de relaciones interpersonales a través de los mismos. Las publicaciones de estos autores permiten basar el análisis en estudios empíricos realizados acerca de la situación y la utilización de tú y usted y, en consecuencia, a través de ellos se puede demostrar la situación actual y real de ambos pronombres y la creación de relaciones interpersonales en la Península Ibérica, aunque se trate solo de algunas zonas de habla ${ }^{5}$.

Por su parte, a diferencia de la metodología empleada en la sección de los pronombres del español, la parte del análisis de los pronombres de segunda persona en euskera no se fundamenta en la revisión de artículos publicados durante el siglo XXI ya que, dentro de mi conocimiento, no se ha producido un abundante número de estudios empíricos que comparen $z u$ e hi para extraer conclusiones acerca de la creación de relaciones interpersonales. Así, el análisis del uso de los

\footnotetext{
${ }^{5}$ No hay ningún estudio empírico que englobe el uso de estos pronombres en todas las comunidades autónomas de la Península Ibérica, probablemente debido a la magnitud del territorio y las diferencias dialectales que de manera obvia afectan al uso de los pronombres en cada zona de habla dentro del español peninsular.
} 
pronombres de segunda persona del singular $z u$ e $h i$ en euskera se basará en los capítulos de la serie Goenkale (en español podría ser traducido como Calle de Arriba) emitidos durante el año 2008 - octava temporada- a través de la cadena de televisión Euskal Irrati Telebista (Radio Televisión Pública Vasca). Esta serie fue emitida entre los años 1993 y 2015, lo cual la clasifica como la serie más longeva del País Vasco en euskera, siendo además uno de los programas con más éxito de audiencia en la historia de Euskal Irrati Telebista en euskera. Para posibilitar el análisis de este estudio, las conversaciones de la mencionada serie fueron extraídas a través del corpus llamado Lexikoaren Behatokiaren Corpusa (Corpus del Observatorio Léxico; http://lexikoarenbehatokia.euskaltzaindia.eus/cgi-bin/kontsulta.py). Por tanto, las conversaciones de dicha serie estaban ya recogidas de manera escrita, en forma de guion, en el corpus. El mencionado corpus es publicado de forma electrónica a través de internet por Euskaltzaindia (Real Academia de la Lengua Vasca) con el objetivo de recoger los materiales publicados por diferentes medios de comunicación en euskera. Como dato, a finales del año 2016, Lexikoaren Behatokiaren Corpusa contaba con 58.576.635 palabras en textos.

La principal razón por la que no se ha realizado un análisis de datos conversacionales espontáneos en euskera es por la ausencia de un corpus en euskera centrado en la interacción verbal espontánea, mínimamente entre dos personas y no en forma de entrevistas. Efectivamente, antes de tomar la decisión de analizar las conversaciones de la introducida serie, se observaron previamente varios corpora de diversos orígenes, todos en euskera. A través de ellos, sin embargo, simplemente se pudieron extraer conversaciones creadas por los hablantes en entrevistas o soliloquios para rememorar conversaciones pasadas (principalmente interacciones supuestamente producidas en el siglo XX). Es cierto que existen corpora de transmisión oral en euskera, no obstante, tal y como se ha mencionado anteriormente, estos son simples soliloquios 
grabados después de haber visto una película o un vídeo, o son partes de entrevistas en las que no están recogidas las intervenciones de los entrevistadores. Además de esto, es destacable la existencia de un número escaso de ejemplos en los que se podía observar el uso de los pronombres de segunda persona del singular.

Con todo esto, se puede justificar la elección de la serie Goenkale como medio central para basar el examen del empleo de los pronombres $z u$ e $h i$, creyendo siempre que dicha serie refleja un uso fidedigno de la situación lingüística del euskera en el País Vasco Occidental durante el siglo XXI. Tal y como establece Nuzzo (2015), el lenguaje utilizado en géneros como las películas no puede ser considerado como un lenguaje natural, aunque varios estudios que comparan el habla de películas y series con el habla natural han demostrado que hay más similitudes que diferencias entre los datos extraídos de las series de televisión y de los datos extraídos del habla espontánea y natural ${ }^{6}$. Además, Quaglio (2013) defiende que los diálogos televisivos tienen que ser naturales y parecerse al habla de la audiencia, porque de lo contrario, los espectadores no se ven reflejados en los personajes de las series.

La forma de obtención de conversaciones con la presencia de los pronombres $z u$ e $h i$ ha sido realizada a través de la descarga de los extractos en forma de guion, publicados en el anteriormente mencionado corpus del euskera (http://lexikoarenbehatokia.euskaltzaindia.eus/cgibin/kontsulta.py). A continuación, se realizó una selección de las conversaciones en las que se

\footnotetext{
${ }^{6}$ Por ejemplo, Rose (2001) analizó los cumplidos y demostró que las fórmulas sintácticas, los temas de los cumplidos, y las estrategias para responder a los cumplidos eran similares en ambos tipos de fuentes, pero encontraron algunas diferencias en lo que a características sociopragmáticas se refiere; Kite y Tatsuki (2005) estudiaron las disculpas y comprobaron que las estrategias pragmalingüísticas utilizadas para las disculpas eran equivalentes en las películas y en el habla natural, aunque algunas características sociopragmáticas, como el género de los hablantes, no coincidía; en un estudio sobre las peticiones llevado a cabo por Fernández-Guerra (2008) se observó que los actos que encabezaban las peticiones y los mecanismos de modificación en vídeos y en el habla natural eran considerablemente similares.
} 
pudiera comprobar la diferenciación en el uso de los pronombres de segunda persona del singular, para así poder crear una lista con todas las conversaciones. Esta selección se hizo mediante la búsqueda explícita de los pronombres de segunda persona del singular en euskera, así como de su morfología verbal, para recoger también aquellas conversaciones con los pronombres omitidos.

En estas conversaciones, los ámbitos más comunes en los que se produjeron las interacciones son dos bares, una comisaría, las casas de los personajes, el ayuntamiento, una empresa dedicada a la pesca, un hotel, la calle, y una escuela de interpretación. Además, se han analizado un total de 35 hablantes: 20 del género femenino y 15 del género masculino. En la Tabla 1 se presenta una diferenciación más detallada de los personajes en cuanto a su edad.

Tabla 1

Categorización de los personajes por edad

\begin{tabular}{|c|c|c|c|c|c|c|}
\hline & $\frac{\frac{\text { Niños/as }}{\text { (hasta } 12}}{\underline{\text { años) }}}$ & $\frac{\text { Adolescentes }}{(12-18 \text { años })}$ & $\frac{\frac{\text { Jóvenes }}{(18-30}}{\underline{\text { años })}}$ & $\frac{\text { Adultos }}{\frac{(30-60}{\underline{\text { años })}}}$ & $\frac{\frac{\text { Mayores }}{\text { (a partir de }}}{\underline{60 \text { años) }}}$ & $\underline{\text { Total }}$ \\
\hline $\begin{array}{l}\text { Género } \\
\text { femenino }\end{array}$ & 1 & 2 & 5 & 9 & 3 & 20 \\
\hline $\begin{array}{l}\text { Género } \\
\text { masculino }\end{array}$ & - & 1 & 6 & 7 & 1 & 15 \\
\hline
\end{tabular}

Por su parte, en la Tabla 2 se pueden encontrar más datos sobre el número de personajes que han establecido una variedad de relaciones interpersonales en la octava temporada de Goenkale. Por lo tanto, por ejemplo, una persona que puede tener relación de hermano o amigo, contará como uno en cada caso. 
Tabla 2

Número de personas con diferente tipo de relación

\begin{tabular}{|c|c|c|c|c|c|c|}
\hline \multicolumn{3}{|c|}{ Tipo de relación } & Femenino & Masculino & \multicolumn{2}{|c|}{ Total } \\
\hline \multirow[t]{4}{*}{ Parejas } & Igual & Joven & 2 & 4 & 6 & 14 \\
\hline & & Adulto & 5 & 3 & 8 & \\
\hline & Desigual & Joven & & & - & \\
\hline & & Adulto & & & - & \\
\hline \multirow[t]{4}{*}{ Hermanos/Hermanas } & Igual & Joven & 4 & 4 & 8 & 9 \\
\hline & & Adulto & & 1 & 1 & \\
\hline & Desigual & Joven & & & - & \\
\hline & & Adulto & & & - & \\
\hline \multirow[t]{4}{*}{ Hijos/Hijas } & Igual & Joven & 5 & 4 & 9 & 12 \\
\hline & & Adulto & & & - & \\
\hline & Desigual & Joven & & 1 & 1 & \\
\hline & & Adulto & & 2 & 2 & \\
\hline \multirow[t]{4}{*}{ Padres/Madres } & Igual & Joven & & & - & 8 \\
\hline & & Adulto & 4 & 2 & 6 & \\
\hline & Desigual & Joven & & & - & \\
\hline & & Adulto & & 2 & 2 & \\
\hline \multirow[t]{4}{*}{ Tíos/Tías } & Igual & Joven & & & - & 7 \\
\hline & & Adulto & 4 & 2 & 6 & \\
\hline & Desigual & Joven & & & - & \\
\hline & & Adulto & & 1 & 1 & \\
\hline \multirow[t]{4}{*}{ Sobrinos/Sobrinas } & Igual & Joven & 2 & 2 & 4 & 8 \\
\hline & & Adulto & & & - & \\
\hline & Desigual & Joven & 2 & 2 & 4 & \\
\hline & & Adulto & & & - & \\
\hline \multirow[t]{4}{*}{ Cuñados/Cuñadas } & Igual & Joven & & & - & 2 \\
\hline & & Adulto & 1 & 1 & 2 & \\
\hline & Desigual & Joven & & & - & \\
\hline & & Adulto & & & - & \\
\hline \multirow[t]{4}{*}{ Suegros/Suegras } & Igual & Joven & & & - & 4 \\
\hline & & Adulto & 2 & 2 & 4 & \\
\hline & Desigual & Joven & & & - & \\
\hline & & Adulto & & & - & \\
\hline \multirow[t]{4}{*}{ Yernos/Nueras } & Igual & Joven & & 1 & 1 & 2 \\
\hline & & Adulto & 1 & & 1 & \\
\hline & Desigual & Joven & & & - & \\
\hline & & Adulto & & & - & \\
\hline \multirow[t]{3}{*}{ Primos/Primas } & Igual & Joven & 3 & 2 & 5 & 5 \\
\hline & & Adulto & & & - & \\
\hline & Desigual & Joven & & & - & \\
\hline
\end{tabular}

(La Tabla 2 continúa) 


\section{$\underline{\text { Tipo de relación }}$}

Adulto

$\underline{\text { Femenino Masculino }}$

$\underline{\text { Total }}$

Abuelos/Abuelas

Igual

Joven

Adulto

Desigual Joven

Adulto

Nietos/Nietas

Igual Joven

Adulto

Desigual Joven

Adulto

Amigos/Amigas

Igual

Joven

Adulto

Desigual Joven

Adulto

Jefes/Jefas

Igual Joven

Adulto

Desigual Joven

Adulto

Empleados/Empleadas Igual

Joven

Adulto

Desigua

Joven

Adulto

Profesores/Profesoras Igual

Joven

Adulto

Desigual Joven

Adulto

Alumnos/Alumnas

Igual

Joven

Adulto

Desigual Joven

Adulto

De este modo, se han recogido un total de 540 conversaciones (extraídos de 60 capítulos emitidos todos en el año 2008) en las que se puede observar un uso diferenciado de los dos pronombres $z u$ e $h i$ en euskera ${ }^{7}$ y, en consecuencia, el análisis del apartado de euskera -para el

\footnotetext{
${ }^{7}$ Como en español, en euskera se pueden omitir a veces los pronombres de sujeto y, por esta razón, en algunas conversaciones se utilizó la morfología verbal para determinar el tipo de pronombre que utilizó el hablante. De todas formas, aunque en una conversación algún hablante omitiera el pronombre de segunda persona del singular, se podía observar su presencia en otra conversación. En esta utilización de pronombre explícito u omitido, en ninguna conversación se ha observado un uso diferenciado, sino que, por el contrario, los hablantes utilizaron el mismo pronombre constantemente con cada interlocutor.
} 
cual se contó el número de cada pronombre en el corpus- se centrará en esas conversaciones. En estas conversaciones, los hablantes siempre hicieron uso de los mismos pronombres con cada hablante, es decir, en ningún momento los hablantes cambiaron de pronombre para dirigirse a un mismo interlocutor. Cabe también mencionar que, de todas las conversaciones recaudadas, un 95.18\% se produjeron siempre entre dos personas, mientras que solamente el $4.81 \%$ de ellas se produjeron entre más de dos personas.

Gracias a la revisión de las publicaciones de los expertos del español mencionados al comienzo de este capítulo y de las conversaciones extraídas de Lexikoaren Behatokiaren Corpusa de la serie Goenkale, se han establecido las siguientes variables para desarrollar una discusión de los datos de manera organizada en el siguiente capítulo:

- Relación de pareja (66 conversaciones en euskera).

- Amistad (201 conversaciones en euskera).

- Familia (228 conversaciones en euskera).

- Asimetría de poder social (45 conversaciones en euskera).

Además de estas variables, es indispensable tener en cuenta el factor del género, así como la edad, ya que dependiendo del sexo y la edad de los hablantes en cada situación conversacional a la hora de analizar el uso de los pronombres de segunda persona del singular en cada idioma se podrán observar resultados y conclusiones más exactas y detalladas. Es por eso que, en el proceso de recaudación de datos, la anotación del género y edad de cada hablante fue una parte fundamental para el consiguiente análisis.

Por tanto, este será un estudio comparativo de los pronombres de segunda persona del singular en el español peninsular y en euskera durante el siglo XXI que dará lugar a conclusiones relacionadas con la creación de relaciones interpersonales entre los hablantes. El número de 
conversaciones recaudadas a través del corpus Lexikoaren Behatokiaren Corpusa servirá para ilustrar la realidad lingüística del euskera en el País Vasco Occidental respecto a los pronombres de segunda persona del singular, y se ahondará en la posible relación que se pueda crear con tú y usted en el español peninsular estableciendo comparaciones con (i) lo que los eruditos del español han descubierto durante el siglo XXI y (ii) lo descubierto en este estudio de la utilización de los pronombres en euskera. Todo esto será analizado con la teoría de la cortesía verbal de Brown y Levinson (1987) que ha sido introducida en profundidad en el Capítulo II. 


\section{CAPÍTULO IV: RESULTADOS}

Los resultados del estudio que se ha realizado en este trabajo acerca de los pronombres de segunda persona del singular del euskera, $h i$ y $z u$, a través del análisis de los diálogos de la serie Goenkale, muestran una gran concordancia con los usos de estas formas de tratamiento que se han descrito más arriba en el Capítulo II. En el presente capítulo se ofrecen dos tablas, respectivamente dedicadas a $h i$ (Tabla 3) y $z u$ (Tabla 4), para presentar de manera visual los datos obtenidos a través de la recogida de conversaciones dentro del corpus Lexikoaren Behatokiaren Corpusa.

Tabla 3

Los usos de hi

\begin{tabular}{|c|c|c|c|c|c|c|c|c|c|c|c|c|c|}
\hline \multirow{4}{*}{ 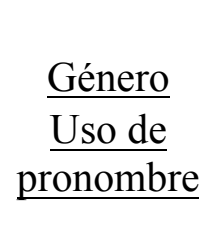 } & \multirow{2}{*}{\multicolumn{4}{|c|}{ Femenino }} & \multicolumn{4}{|c|}{$\underline{H i}$} & \multirow{2}{*}{\multicolumn{5}{|c|}{ Femenino y masculino }} \\
\hline & & & & & & $\overline{\text { Masc }}$ & lino & & & & & & \\
\hline & \multicolumn{2}{|c|}{$\underline{\text { Recíproco }}$} & \multicolumn{2}{|c|}{$\stackrel{\text { No }}{\text { recíproco }}$} & \multicolumn{2}{|c|}{$\underline{\text { Recíproco }}$} & \multicolumn{2}{|c|}{$\underset{\text { recíproco }}{\text { No }}$} & \multicolumn{2}{|c|}{$\underline{\text { Recíproco }}$} & \multicolumn{2}{|c|}{$\stackrel{\stackrel{\text { No }}{\text { recíproco }}}{\underline{\underline{n}}}$} & \multirow[t]{2}{*}{ Total } \\
\hline & $\underline{\mathrm{N}^{\mathrm{o}}}$ & $\underline{\%}$ & $\underline{\mathrm{N}}^{\mathrm{o}}$ & $\underline{\%}$ & $\underline{\mathrm{N}^{\mathrm{o}}}$ & $\underline{\%}$ & $\underline{\mathrm{N}^{\mathrm{o}}}$ & $\underline{\%}$ & $\underline{N}^{o}$ & $\underline{\%}$ & $\mathrm{~N}^{o}$ & $\underline{\%}$ & \\
\hline Pareja & 0 & - & 0 & - & 4 & 100 & 0 & - & 0 & - & 0 & - & 4 \\
\hline Amis & 12 & 9.09 & 0 & - & 67 & 50.75 & 8 & 6.06 & 42 & 31.81 & 3 & 2.27 & 132 \\
\hline Familia & 0 & - & 0 & - & 36 & 40 & 31 & 34.44 & 21 & 23.33 & 2 & 2.22 & 90 \\
\hline $\begin{array}{l}\text { Asimetría } \\
\text { de poder } \\
\text { social }\end{array}$ & 0 & - & 0 & - & 0 & - & 2 & 100 & 0 & - & 0 & - & 2 \\
\hline Total & 12 & $\begin{array}{l}5.26 \\
12(5\end{array}$ & $26 \%$ & - & 107 & $\begin{array}{l}46.92 \\
148(6\end{array}$ & $\begin{array}{l}41 \\
.91 \%\end{array}$ & 17.98 & 63 & $\begin{array}{l}27.63 \\
68(29\end{array}$ & $\begin{array}{c}5 \\
82 \%)\end{array}$ & 2.19 & 228 \\
\hline
\end{tabular}

Más concretamente, empezando con el pronombre $h i$, y estableciendo una comparación entre los géneros, se puede observar que una más que mayoría de los casos encontrados, se produce entre los hombres -solo un total de 12 casos de $h i$ se produjeron entre mujeres, frente a un total de 148 entre hombres. En porcentajes, esto se traduce en 5.26\% en el caso de las mujeres y en $64.91 \%$ en el caso de los hombres, ya sea de manera recíproca o asimétrica. De hecho, no se ha encontrado ningún caso de $h i$ entre mujeres en el ámbito de la pareja, familia, y la asimetría 
de poder social. De entre los chicos, hay que destacar que, en 41 conversaciones (17.98\%), este pronombre no se produjo de forma recíproca, mientras que en 107 conversaciones (46.92\%) sí. En cambio, en las conversaciones entre ambos géneros, parece que no es tan inusual encontrar casos recíprocos de $h i(63-27.63 \%$ - de un total de 68 conversaciones $)$, pero eso sí, solamente entre amigos, y familiares, no así en las conversaciones entre parejas y en las relaciones marcadas por la distancia y el poder social. En cualquier caso, se deberá concretar, por ejemplo, qué tipo de relación de amistad o familiar mantienen los interlocutores en cada situación. Es destacable también que tal y como se ha narrado en el Capítulo II, este pronombre no se utiliza entre las parejas y, en la Tabla 3, se puede comprobar que solo se han encontrado 4 excepciones, las cuales se produjeron entre una pareja de chicos antes de casarse (no se puede concluir lo mismo de una pareja de chicas porque en la serie no hay ninguna pareja homosexual femenina que utilice este pronombre).

Tabla 4

Los usos de zu

\begin{tabular}{|c|c|c|c|c|c|c|c|c|c|c|c|c|c|}
\hline \multirow{4}{*}{$\frac{\underline{\text { Género }}}{\underline{\text { Uso de }}}$} & \multicolumn{12}{|c|}{$\underline{Z u}$} & \multirow{4}{*}{ Total } \\
\hline & \multicolumn{4}{|c|}{$\underline{\text { Femenino }}$} & \multicolumn{4}{|c|}{ Masculino } & \multicolumn{4}{|c|}{ Femenino y masculino } & \\
\hline & \multicolumn{2}{|c|}{$\underline{\text { Recíproco }}$} & \multicolumn{2}{|c|}{$\stackrel{\text { No }}{\text { recíproco }}$} & \multicolumn{2}{|c|}{$\underline{\text { Recíproco }}$} & \multicolumn{2}{|c|}{$\underset{\text { recíproco }}{\stackrel{\text { No }}{n^{2}}}$} & \multicolumn{2}{|c|}{$\underline{\text { Recíproco }}$} & \multicolumn{2}{|c|}{ recíproco } & \\
\hline & $\mathrm{N}^{\mathrm{o}}$ & $\underline{\%}$ & $\mathrm{~N}^{\mathrm{O}}$ & $\underline{\%}$ & $\underline{N}^{o}$ & $\underline{\%}$ & $\mathrm{~N}^{\circ}$ & $\underline{\%}$ & $\mathrm{~N}^{\mathrm{o}}$ & $\underline{\%}$ & $\underline{\mathrm{N}}^{\circ}$ & $\underline{\%}$ & \\
\hline Pareja & 4 & 6.45 & 0 & - & & 1.61 & 0 & - & 57 & 91.93 & 0 & - & 62 \\
\hline Ami & 62 & 77. & 0 & - & & - & 8 & 10 & & 8.75 & & 3.75 & 80 \\
\hline Familia & 51 & 29.82 & 0 & - & 16 & 9.35 & 31 & 18.12 & 71 & 41.52 & 2 & 1.16 & 171 \\
\hline $\begin{array}{l}\text { Asimetría } \\
\text { de poder } \\
\text { social }\end{array}$ & 13 & 28.88 & 0 & - & 1 & 2.22 & 2 & 4.44 & 29 & 64.44 & 0 & - & 45 \\
\hline Total & 130 & $\begin{array}{r}36.31 \\
130(36 \\
\end{array}$ & $\begin{array}{c}- \\
31 \%) \\
\end{array}$ & - & 18 & $\begin{array}{l}5.02 \\
59(1\end{array}$ & $\begin{array}{c}41 \\
6.48) \\
\end{array}$ & 11.45 & 164 & $\begin{array}{c}45.81 \\
169(4\end{array}$ & $\begin{array}{c}5 \\
.2 \%)\end{array}$ & 1.39 & 358 \\
\hline
\end{tabular}

Si se centra la atención en la Tabla 4, dedicada al otro pronombre de segunda persona del singular en euskera, $z u$, se demuestra un uso más regular comparado con $h i$, de acuerdo con los 
datos descritos en el Capítulo II. Empezando por las parejas, no se encuentra ningún uso no recíproco independientemente del género de los hablantes ya que el uso de $h i$ en este ámbito está restringido. En cuanto a la amistad, los hombres utilizan definitivamente más hi de forma recíproca (en 67 conversaciones) que $z u$ (no se ha encontrado su uso simétrico en ninguna interacción) entre ellos, a diferencia de las mujeres. De hecho, es revelador que no se haya encontrado ningún caso en el que los hombres unidos por una amistad utilicen $z u$ de forma simétrica. Si se fija ahora en la variante de la familia, es difícil extraer conclusiones en este nivel ya que hay que tener en cuenta la relación que hay entre los hablantes y, por lo tanto, será necesario discutirlo a continuación con ejemplos extraídos de las conversaciones. Finalmente, se observa que, en las interacciones con asimetría de poder social entre los participantes, es más común utilizar el pronombre $z u$ ( 45 casos) que $h i$. De hecho, $h i$ solamente se encontró en 2 de estos casos, produciéndose de forma asimétrica y entre hombres. Para estas dos excepciones, no se ha podido encontrar la razón de la existencia de esta asimetría por falta de pruebas, pero una justificación válida podría ser que en ambos casos los hablantes son hombres que se conocen y que pertenecen a generaciones diferentes, características que no se han producido en las otras conversaciones marcadas por la asimetría de poder. En cualquier caso, dado que este fenómeno se ha producido solamente en 2 casos de todos los encontrados, las explicaciones que se han ofrecido aquí son solo conjeturas.

Aun siendo así las cosas, esta primera evaluación no es suficiente para una completa interpretación de los resultados, y por ello, será necesario realizar un análisis de los datos en profundidad y con ejemplos de cada variable en las siguientes secciones de este capítulo. Uno de los factores más importantes en este análisis será concretar el tipo de relación que crean las personas dentro de las variantes aquí establecidas, teniendo en cuenta los conceptos de cortesía 
positiva y negativa, y las amenazas a la imagen social de los interlocutores. La interpretación de los datos del euskera obtenidos para el presente estudio, serán contrastados con lo que algunos eruditos del español peninsular, mencionados en el Capítulo III, han descubierto con sus estudios.

\section{Las Parejas}

Examinando primero el español, en las conversaciones entre parejas, Sanromán Vilas (2010) reveló con su estudio de los pronombres de segunda persona del singular en Vigo y Madrid, un uso completamente dominado por el pronombre de segunda persona del singular tú de forma recíproca en todos los casos y contextos posibles. El estudio de Sampedro Mella (2016) del español centro-norteño, refleja sin ninguna duda la misma línea de Sanromán Vilas (2010) al tratarse de personas conocidas y próximas. Montero Curiel (2011), con su estudio en Extremadura, no extrajo conclusión alguna acerca de esta variable, pero Pedroviejo Esteruelas (2006), centrado en Valladolid, también encontró un uso absolutamente simétrico del pronombre tú entre las parejas. Por tanto, no cabe duda de que, tratándose de relaciones estrechas entre dos personas, se crea una relación íntima con el uso simétrico de tú como parte de la cortesía positiva y, por consiguiente, en un principio, no hay amenazas a la imagen social de ningún interlocutor.

En cambio, con los datos que se han recaudado del euskera, se deduce un uso dominado por $z u$ en lo que a esta variable respecta: todos utilizan el pronombre $z u$ de forma simétrica, independientemente del tiempo que lleven juntos e incluso de si son parejas homosexuales (femeninas en este caso) o heterosexuales, de acuerdo con las Tablas 3 y 4 . Esto se ejemplifica en (1) entre una mujer y un hombre que están casados y que son adultos, en (2) con una pareja de chicas adultas que no están casadas, y en (3) con una pareja joven heterosexual que no están 
casados y que son primos - no por relación sanguínea- que desde su infancia han vivido en el mismo hogar. En estos casos, zu no sería interpretado como parte de las estrategias de la cortesía negativa o de cortesía positiva, sino como un pronombre pragmáticamente no marcado.

(1)

1 Leonor Naroak afaltzera gonbidatu nau. Nekane, Mimi, bera eta ni. Naroa me ha invitado a cenar. Nekane, Mimi, ella y yo.

2 Koldo Eta ahaztu egin zaizu! $¡ Y$ se te ha olvidado!

3 Leonor Bai, oraintxe deituko diot ez noala esateko.

4 Koldo Itxoin... zoaz afaltzera! ¡Espera... vete a cenar!

5 Leonor Ezetz, Koldo. Lehenbailehen oheratu eta zuri besarkatuta egon nahi dut, ulertzen?

Que no, Koldo. Quiero acostarme cuanto antes y estar abrazada a ti, ¿entiendes?

6 Koldo Entzuidazu, Atxurin Nekanerekin egin dut topo eta zerbait ezkutatzen dugula igarri didala uste dut.

Escúchame, me he encontrado a Nekane en Atxuri y creo que me ha notado que escondemos algo.

7 Leonor $A i$, virgencita...

Ai, virgencita...

8 Koldo Zoaz afari horretara eta ahalik eta alaien egoten saiatu. Vete a esa cena e intenta estar lo más contenta posible.

9 Leonor Ok! Ok. Ronzito bat hartuko dut eta inork ez dit ezer antzemango. Ok! Ok. Me tomaré un roncito y nadie me notará nada.

10 Koldo Zoaz eta saiatu ondo pasatzen.

Ve e intenta pasarlo bien.

11 Leonor Eta zuk zer egin behar duzu hemen bakarrik? ¿Y tú qué vas a hacer aquí solo?

12 Koldo Niregatik ez arduratu. Ohera joango naiz. Gaurko eguna ahaztu egin nahi dut.

No te preocupes por mí. Iré a la cama. Quiero olvidar el día de hoy.

13 Leonor Bihar ere egunak argituko du, mi amol. Diru hori lortuko dugu. Egongo da moduren bat.

Mañana también amanecerá, mi amol. Conseguiremos ese dinero. Habrá algún momento.

14 Koldo Zu bezain baikorra izan nahi nuke. Tira, zoaz.

Me gustaría ser tan positivo como tú. Anda, vete.

15 Leonor Zerbait jantzi eta banoa!

¡Me pongo algo y me voy! 
(2)

1 Naroa Orduan, nik erosiko dut ogia, bale?

Entonces, compraré el pan, ¿vale?

2 Nekane Bale. Nikfruta, azoka bidean daukat-eta.

Vale. Yo la fruta porque el mercado me pilla de camino.

3 Naroa Ederki. Gero arte, orduan.

Bien. Hasta luego, entonces.

4 Nekane Adio, bai!

¡Sí, adiós!

5

(Baina ez dira mugitzen).

(Pero no se mueven).

6 Nekane Zuk ez al zenuen joan behar?

¿Tú no tenías que irte?

7 Naroa Bai. Eta zuk?

Sí. ¿Y tú?

8 Nekane Nik be bai. Baina zoaz zu aurrena.

Yo también. Pero ve tú primero.

9 Naroa Musu bat emango nizuke oraintxe bertan.

Te daría un beso ahora mismo.

(3)

1 Lukas Ikerne. Kaixo!

Ikerne. ¡Hola!

2 Ikerne Kaixo...

Hola...

3 Lukas Nolatan zu hemen? Hau sorpresa polita.

¿Cómo tú por aquí? Qué sorpresa tan bonita.

4 Ikerne Hemen zeundela esan didate eta...

5 Lukas Zoragarrizaude.

Estás estupenda.

6 Ikerne Eskerrik asko.

Muchas gracias.

7 Lukas Jateko modukoa. Eta, bestela, zer moduz?

Para comerte. ¿Y, lo demás, qué tal?

8 Ikerne Bueno...

Bueno...

9 Lukas Zerbait gertatzen da?

¿Ocurre algo?

10 Ikerne Bai. Ez da oso larria... Berez, tontakeria bat irudituko zaizu.

Sí. No es muy grave.... En realidad, te parecerá una tontería.

11 Lukas Esan!

¡Dilo!

12 Ikerne Ume-umetatik ezagutzen dugu elkar eta... bikote baten oinarria konfiantza omen da eta...

Nos conocemos desde que éramos niños y... parece que la base de una relación es la confianza y... 


\section{Lukas Ondo zaude?}

¿Estás bien?

14 Ikerne Bai, bai, lasai. Ondo nago. Benetan. Zu zer? Kafea hartzen?

Sí, sí, tranquilo. Estoy bien. De verdad. ¿Tú qué? ¿Tomando café?

15 Lukas Bai. Nahi?

Sí. ¿Quieres?

16 Ikerne Ez, nahikoa urduri nago dagoeneko.

No, ya estoy bastante nerviosa.

Con las conversaciones en (1), (2), y (3) se puede defender que, en las conversaciones de parejas, $z u$ no sería interpretado como parte de las estrategias de la cortesía negativa, sino como un pronombre pragmáticamente no marcado. Esto se puede comprobar en las líneas 11 y 14 en (1), en las líneas 6,7 , y 8 en (2), y en 3 y 14 en (3) ya que con el uso de zu ningún hablante de estos casos trata de marcar distancia, respeto, o deferencia, sino que, por el contrario, las relaciones que establecen son cercanas e íntimas. Incluso, esto se debe a que de acuerdo con los usos establecidos de los pronombres en euskera, las parejas no tienen la posibilidad de emplear $h i$-ni de forma simétrica ni asimétrica- entre ellos, y zu es así el pronombre utilizado en las conversaciones de esta variable. Es decir, al menos en las conversaciones que se han recaudado y que se agrupan dentro de esta categoría, la elección entre $h i$ o zu no tendría consecuencias respecto a la cortesía. Además, en todas las conversaciones, el uso de $z u$ se produce de forma simétrica, como en las líneas 11 y 14 en (1), en las líneas 6 y 7 en (2), y finalmente, en las líneas 3 y 14 en (3).

La única excepción que se encontró, tal y como se comprobó en la Tabla 3, es una pareja joven homosexual masculina que utilizó el pronombre $h i$ de forma simétrica, como se puede observar en la conversación en (4).
1 Alex
Bueno, hasi heu. Bueno, empieza tú.
2 Markel Ez, heu aurrena. 


\author{
No, tú primero. \\ 3 Alex Hi agertu haiz hotelean ezustean. \\ Has aparecido tú en el hotel por sorpresa. \\ 4 Markel Ja, baina hik ere gauza garrantzitsuren bat esan behar didak, ezta? \\ Ya, pero tú también me tienes que decir algo importante, ¿verdad? \\ 5 Alex A ze korapiloa! \\ ¡Vaya lío! \\ 6 Markel Hasi orduan askatzen. \\ Entonces empieza a soltarlo. \\ 7 Alex Konforme, neu hasiko nauk. \\ De acuerdo, empezaré yo.
}

La utilización simétrica de este pronombre -como se observa en las líneas 3 y 4 en (4)es una representación del pronombre de la cortesía positiva. Se puede deducir que con el uso simétrico de este pronombre no se produce ningún acto de amenaza a la imagen de los dos interlocutores. No obstante, las conversaciones como (4) son excepciones que no se pueden comprobar con los usos que se han narrado más arriba en el Capítulo II debido a que ninguno de los autores allí revisitados, hacen referencia al tipo de pronombre que utilizan las parejas homosexuales; hacen referencia únicamente al uso de los pronombres de segunda persona del singular por parte de las parejas heterosexuales. Además, este uso simétrico de $h i$ en una pareja de chicos, ha podido comprobarse tan solo en cuatro conversaciones, así que no hay material suficiente para extraer conclusiones acerca del uso de pronombres en este tipo de parejas.

Se puede presumir así que la relación que establecen las parejas en español peninsular mediante el uso recíproco de tú -cortesía positiva- es una relación simétrica, cercana e íntima en la que no se vislumbra ni un ápice de amenaza a la imagen social de los interlocutores. Si se compara este hecho con el euskera, apoyando los argumentos en los ejemplos aquí presentados, se concluye que por lo menos con el uso de los pronombres, tampoco se producen actos de amenaza a la imagen social de los interlocutores ya que todas las parejas utilizan $z u$ de forma recíproca. Esto es, siendo en estos casos zu un pronombre no marcado pragmáticamente, y 
empleándolo de manera recíproca, ningún hablante adquiere una posición superior a la de su interlocutor. La única excepción a esta regla del euskera es que en 4 ocasiones una pareja homosexual ha utilizado hi de forma simétrica, creando igualmente, una relación de igualdad, solidaridad, e intimidad. Por tanto, $z u$, al menos en el ámbito de la pareja, no sería parte de la cortesía negativa, sino un recurso lingüístico que no tiene valor como una estrategia de cortesía, pero que a través del cual se establecen relaciones simétricas, igualitarias, solidarias, y cercanas.

En un examen inicial se podría defender que el hecho que diferencia al euskera del español de la Península Ibérica, con lo que respecta a esta variable, es que la utilización simétrica de $z u$ en las parejas, podría ser interpretada como la creación de una relación social más distante que la relación íntima que se crea a través de tú. Sin embargo, no deberían extraerse conclusiones de forma tan rápida en el caso del euskera. Uno de los puntos a considerar es que, tal y como se establece en las descripciones de los usos de los pronombres de segunda persona del singular en euskera, no se suele producir el uso de $h i$ entre los cónyuges (Alberdi, 1991; de Rijk, 1991, 2008; Trask, 2003), aunque en los trabajos visitados para este estudio, esta afirmación no ha sido comprobada con estudios empíricos. De todas maneras, es un hecho que se respeta de forma tajante en las conversaciones que se producen en la serie, exceptuando cuatro casos. Por tanto, a través del uso simétrico de $z u$ y de la consecuente ausencia de amenazas, se crean unas relaciones tan íntimas y recíprocas como con tú, interpretando en este caso $z u$ como pronombre no marcado (Alberdi, 1991; de Rijk, 1991, 2008) por no tener la oportunidad de emplear $h i$ en esta variable. De hecho, todas las mujeres que participan en las conversaciones de (1), (2), y (3) no utilizan el pronombre $h i$ sin importar si se encuentran en familia o entre amigas de su mismo sexo. En su caso, $z u$ es definitivamente un pronombre no marcado pragmáticamente. En cambio, aunque los personajes de Koldo en (1) y Lukas en (3) no utilicen $h i$ con sus respectivas parejas - 
en línea con las reglas de uso de este pronombre-, se podrá ver que dependiendo de la variante y de la relación que mantengan con sus interlocutores, emplearán $h i$ en lugar de $z u$, por ejemplo, con amigos.

\section{La Amistad}

De forma similar a la variable de las parejas en el caso del español peninsular, Sanromán Vilas (2010) revela en su estudio centrado en Vigo y en Madrid que tú es el único pronombre que utilizan todas las generaciones para dirigirse a amigos de edad similar, afirmación con la cual los estudios de Montero Curiel (2011) - estudio realizado en Extremadura- y Pedroviejo Esteruelas (2006) - estudio realizado en Valladolid- están en concordancia. Sampedro Mella (2016), ajustado al español centro-norteño, destaca el factor del conocimiento y la proximidad para reflejar un uso absolutamente dominado por el pronombre tú dentro de esta variante. Sin embargo, ambos (Sampedro Mella, 2016; Sanromán Vilas, 2010) han descubierto que, entre amigos con diferencia de edad, es común utilizar usted para referirse al interlocutor mayor, mientras que estos utilizan tú para dirigirse a sus amigos más jóvenes. Sanromán Vilas (2010) es más concreto en este tema porque descubrió que las personas que nacieron a partir de las generaciones entre 1950-69, utilizan siempre tú de forma recíproca, exceptuando algún caso poco usual con un uso asimétrico de los pronombres.

En euskera, entre las chicas de esta serie se ha encontrado el uso del pronombre $h i$ de forma simétrica en tan solo 12 conversaciones, mientras que entre los hombres en 67 conversaciones. Todos estos casos son también entre personas que pertenecen a una misma generación: jóvenes en el caso de las chicas, y en el caso de los chicos los casos aquí obtenidos pertenecen a generaciones tanto jóvenes como mayores. Este dato apoya la idea de que entre los 
hombres se utiliza más este pronombre y que, de hecho, es un fenómeno en peligro de extinción entre las mujeres (Amorrortu, 2003). El uso simétrico de hi entre amigos del mismo género se representa aquí en (5) entre chicas, y en (6) entre chicos.

1 Lukas Lasaitu hadi. Tranquilízate.

2 Kevin Ez dinat beste aukerarikizan. No he tenido otra opción.

3 Rakel Baina, bueno, a ze kopeta! Botata utzi zenuten baserrian eta gero eskuak garbitu dituzue!

¡Pero, bueno, qué morro! ¡Lo dejasteis tirado en el caserío y luego os habéis limpiado las manos!

4 Kevin Ez hadi tartean sartu. Joana eta Lukas nirekin egon ditun hasieratik. No te metas. Joana y Lukas han estado conmigo desde el principio.

5 Rakel Ja, ikusten diat!

¡Ya lo veo!

6 Joana Itxi zan mokoa.

¡Cállate!

7 Rakel Orduan, zergatik haserretu dituk hirekin, e? Egia esan dualako? A ze lagunak!

Entonces, ¿por qué se han enfadado contigo, e? ¿Porque has dicho la verdad? ¡Vaya amigos!

8 Lukas Gu ez gauden haserre. Gertatutakoa jakin nahi dinagu, besterik ez. Nosotros no estamos enfadados. Solo queremos saber lo ocurrido, sin más.

9 Rakel Ez nauk hitaz ari, (Joana seinalatuz) beste oilobusti honetaz baizik. Kevinen lekuan polita egongo hintzanake.

No estoy hablando de ti, (señalando a Joana) sino de esta otra gallina. Estarías tú buena en el lugar de Kevin.

10 Joana Baina hi nor haiz niri ezer esateko? ¿Pero tú quién eres para decirme algo a mí?

11 Rakel Kevinen laguna! Eta eskubide osoa zeukanat defendatzeko! ¡La amiga de Kevin! ¡Y tengo todo el derecho de defenderlo!

12 Joana Ipuin askotxo irakurri ditun hik.

Tú has leído demasiados cuentos.

13 Rakel Ez naun koldar mingulin bat, hi bezala. Yo no soy una cobarde, como tú.

14 Lukas Nahikoa da!

¡Ya basta!

(6)

1 Lukas Orduan animatzen haiz? ¿Entonces te animas?

2 Kevin Ezin diat, berehala itzuli behar diat hotelera. Erreminta batzuen bila 
atera nauk.

No puedo, tengo que volver enseguida al hotel. He salido a buscar algunas herramientas.

3 Lukas Hi bai koldarra.

Tú eres un cobarde.

4 Kevin Zer?

¿Qué?

5 Lukas Tipo ausarta hintzela uste nian. Tipo... arriskutsua.

Creía que eras una persona valiente. Un tipo... peligroso.

6 Kevin Ez adarrik jo, txikito. Gorriak pasatu dizkiat nik. Hik, berriz, ez dakik zer den kaleko gordina, pijo hutsa haiz.

No me tomes el pelo, chaval. Yo lo he pasado muy mal. Tú, en cambio, no sabes lo que es la dureza de la calle, eres un pijo.

Con el uso simétrico de este pronombre -en las líneas 10, 12, y 13 en (5), y en las líneas 3 y 6 en (6)-, los hablantes están creando relaciones cercanas e íntimas entre ellos, de la misma forma que ocurre en el español peninsular. Esta aseveración también puede comprobarse con el tipo de expresiones que utilizan los hablantes en las líneas 6, 10, y 11 de (5), y en las líneas 3 y 6 de (6), ya que son expresiones que suelen utilizarse solamente entre personas con las que existe una relación cercana y de igualdad. Al usar el pronombre de la cortesía positiva -hi- de manera recíproca en este contexto, no se marca ninguna distancia entre los interlocutores y tampoco se crea ninguna amenaza en este tipo de conversaciones recogidas para este estudio.

Entre las chicas, se observa que, el pronombre $z u$, de forma simétrica, se ha producido más veces que $h i$, como en (7). Esto difiere de los datos de los chicos, ya que en las conversaciones de Goenkale que se han recogido para este trabajo, no se ha encontrado ningún caso de $z u$ recíproco entre amigos. Este factor apoya de nuevo el hecho de que $h i$ es más habitual entre chicos que entre chicas (Amorrortu, 2003).

1 Naroa Hara, Nekane! Zer, galduta? ¡Mira, Nekane! ¿Qué, perdida?

2 Nekane Haize apur bat behar nuen. Ito beharrean nengoen eta. Eta zu, zelan ba hemen?

Necesitaba un poco de aire. Estaba ahogándome. ¿Y tú, qué haces aquí? 
3 Naroa Lanean. Beste bezero bat lortu dut, eta pozik.

Trabajando. He conseguido otro cliente, y contenta.

4 Nekane Zorionekoa zu! Ni nazka-nazka eginda nago nire behar

madarikatuarekin.

¡Qué suerte tienes! Yo estoy cansadísima con mi maldito trabajo.

5 Naroa Bai zera! Zuk atsegin duzu zure lana.

¡Qué dices! A ti te gusta tu trabajo.

6 Nekane Ez dizut esango ezetzik, baina azken boladan komisarian sartu orduko, beti daukat norbait errieta egiteko zain.

No te diré que no, pero últimamente al entrar en la comisaría, siempre tengo a alguien esperándome para echarme la bronca.

En (7), Naroa y Nekane mantienen una relación íntima y son compañeras de piso. En su caso, la utilización recíproca de $z u$-en las líneas 2, 4, y 5- no es un caso de la cortesía negativa y tampoco se produce ningún acto de amenaza a la imagen social de cada una. Más bien, es otro caso del pronombre pragmáticamente no marcado, debido a que en todas sus conversaciones con amigos, compañeros de trabajo o desconocidos- siempre utilizan este pronombre. De esta forma, se justifica que con $z u$ en estos contextos no se transmiten significados de cortesía negativa, sino que parece que este pronombre es neutral en cuanto a la creación de relaciones.

En las conversaciones entre amigos de ambos sexos también se ha encontrado el uso simétrico de $h i$ en 42 casos, como se ilustra en (8). Por tanto, aparte de en las interacciones entre amigos del mismo género, entre chicos y chicas también es posible crear relaciones íntimas y simétricas con $h i$, como en la línea 3 de (8) cuando Rakel dice que son amigos y que se tienen que ayudar mutuamente.

1 Rakel Zer daukak? Kontaidak, mesedez. ¿Qué te pasa? Cuéntamelo, por favor.

2 Kevin Oker hago, Rakel, ez dun hik pentsatzen duana, baina ezin dinat ezer esan.

Estás equivocada, Rakel, no es lo que tú te piensas, pero no te puedo decir nada.

3 Rakel Lagunak gaituk, Kevin, eta elkarri laguntzeko gaudek. Nik gaizki pasatu nuenean, hik lagundu hidan; orain utzidak niri.

Somos amigos, Kevin, y estamos para ayudarnos el uno al otro. Cuando 


\section{Kevin Baserriko sutean han nengonan ..., gizon hura hil zunan sutean. Begira (zauria erakusten dio). Eta ez naun medikuarengana joan... \\ Estaba en el incendio del caserío..., en el incendio en el qu ese murió aquel hombre. Mira (le enseña la herida). Y no he ido al médico...}

Es curioso, que tal y como se narró en el Capítulo II, hi se suele utilizar más entre personas del mismo sexo -sobre todo entre hombres y no tanto entre mujeres- que entre interlocutores de diferentes sexos (Alberdi, 1991; Trask, 2003), pero los datos obtenidos de la serie Goenkale contrastan con esta afirmación, al menos en 42 conversaciones entre amigos de ambos géneros. Lo cierto es que esta afirmación en cuanto al uso más típico de $h i$ entre personas del mismo sexo en lugar de entre personas de ambos sexos no ha sido comprobada por estudios empíricos, al menos en todos los trabajos que se han visitado para realizar el presente análisis. Por lo tanto, esta diferencia respecto al uso de $h i$ entre los trabajos de Alberdi (1991) y Trask (2003) y lo descubierto con Goenkale, puede deberse a que se trata de diálogos que pertenecen a una serie y no a conversaciones auténticas. Sin embargo, teniendo en cuenta que los 42 casos se han producido por adolescentes o hablantes jóvenes, también podría justificarse que la diferencia se debe a un cambio generacional. En cualquier caso, con los diálogos de la serie se comprueba que es posible generar relaciones interpersonales idénticas entre chicos y chicas que son amigos, además de entre amigos del mismo sexo, mediante el uso recíproco de $h i$, como en las líneas 2 y 3 de (8). En todos estos casos, tanto en interacciones entre amigos del mismo sexo o del sexo contrario, este pronombre de la cortesía positiva marca solidaridad, intimidad y cercanía -por ejemplo, por las expresiones íntimas y de confianza que emplean los hablantes en las líneas 6, 10, y 11 en (5), y en las líneas 3 y 6 de (6), y también, por la franqueza y sinceridad que se observa en las líneas 2 y 3 en (8). 
Por otro lado, los números de tratamiento asimétrico entre chicos -solo 8 conversaciones, lo cual representa el $6.06 \%$ de las conversaciones dentro de esta variable-, y entre chicos y chicas -solo 3 conversaciones, lo que se traduce en el $2.27 \%$ de las conversaciones marcadas por una amistad- son muy escasos y por eso no son representativos. En estos casos, es de notable importancia considerar otros factores como la diferencia de edad, como en (9).

1 Andoni Hildakoa kaleko eskaleren bat zelakoan gaude. Creemos que el muerto era un mendigo.

2 Abel Bai. Holako tokietan bilatzen dik babesa jende horrek. Goxo egoteko sua piztu eta akabo!

Sí. Esa gente encuentra refugio en sitios como ese. ¡Encender el fuego para estar calentito y ya está!

3 Andoni Ez zabiltza oker. Hori da esku artean daukagun hipotesia.

No va por mal camino. Esa es la hipótesis que tenemos entre manos.

4 Abel Gogoan diat antzeko kasu bat. Aramaion gertatu zuan.

Me recuerda a un caso parecido. Ocurrió en Aramaio.

5 Andoni Era guztietako kasuak ikertu dituzu ezta?

¿Ha investigado todo tipo de casos, verdad?

6 Abel Zer nahi duk? Maite diat lanbide hau eta onena eman zioat. ¿Qué queréis? Amo este trabajo y le doy lo mejor.

7 Andoni Zukdakizunaren erdia jakingo bagenu! ¡Si supiéramos la mitad de lo que usted sabe!

8 Abel Tira, tira, ez duk horrenbesterako ere. Lortu duk Nekanerekin hitz egitea? Bueno, bueno, tampoco es para tanto. ¿Has conseguido hablar con Nekane?

9 Andoni Ez. Lanpetuta dabil Milenaren kasuarekin eta kontatuko diot itzultzen denean.

No. Está ocupada con el caso de Milena y se lo diré cuando vuelva.

10 Abel Bistan zagok. Azkenean heure esku zagok kasua. Andoni, hik ez duk Nekane leku txarrean utzi nahi, baina hemen norberak irabazten dik bere fama.

Está claro. Al final el caso está en tus manos. Andoni, tú no quieres dejar en mal lugar a Nekane, pero aquí cada uno tiene su fama.

11 Andoni Nekane oso buruzagi ona da.

Nekane es muy buena jefa.

12 Abel Hala izango duk. Baina lehen ere esan nian, emakume hori ez duk egokia kasua eramateko. Lotura handiegia zaukak umearekin.

Así será. Pero ya te lo dije antes, esa mujer no es la adecuada para llevar el caso. Tiene demasiada relación con la niña. 
La razón por la cual en (9) hay un tratamiento asimétrico -en las líneas 7 y 10- de los pronombres se debe a que entre ambos hablantes existe una diferencia de edad considerable. Aunque hace años que se conocen y han trabajo juntos durante muchos años, Abel es un hombre que está a las puertas de la jubilación, mientras que Andoni tiene alrededor de cuarenta años. Lo cierto es que, con todas sus conversaciones recaudadas, se observa que tienen una relación cercana, pero, no obstante, respetan los usos de los pronombres. Por ello, en su caso se podría decir que la imagen social de Abel está siendo respetada por utilizar el pronombre de la cortesía negativa $z u$. En cambio, la utilización de $h i$ por parte de Abel para dirigirse a Andoni, podría ser entendida como un acto de amenaza a la imagen social del receptor -aunque es poco probable dada la relación cercana que ambos mantienen- dado que Abel adquiere una identidad superior a la de su interlocutor. Esto es, Andoni está tratando a Abel de una forma respetuosa, distante, y deferente, pero, por el contrario, Abel se refiere a Andoni como superior y así Andoni no recibe el mismo trato de respeto y de distancia, como en la línea 10 en (9).

Pero el grado de conocimiento o la utilización de un dialecto concreto del euskera también pueden causar consecuencias en la elección del pronombre adecuado entre amigos, como en (10).

1 Tximista Nikjakin bazakinat mojito bat prestatzen, baina... 'ttak!' Leonorren eskua falta! Yo sé preparar un mojito, pero... ‘¡tac!' ¡Falta la mano de Leonor!

2 Itxaso Ai, muchachito, horretarako Kuban jaio behar da. Uztazu! $\mathrm{Ai}$, muchachito, para eso hay que nacer en Cuba. ¡Déjalo/Déjelo!

3 Tximista Utzi nik? Ezta... Tira, esaidan, egongo dun sekretutxoren bat... ¿Dejarlo yo? Ni... Bueno, dime, habrá algún secreto...

4 Itxaso Badago, bai, baina... Lo hay, sí, pero...

5 Tximista Esan, esan! ¡Dilo, dilo!

6 Itxaso Kontatuko banizu, akabo sekretua. Y eso sí que no! $\mathrm{Si}$ te/se lo contara, se acabaría el secreto. ¡Y eso sí que no! 
7 Tximista Hi, politta, konfiantzakoa naun ni, aditu? Etzionat inori esango, ezta txintik ere. Esaidan.

Tú, bonita, yo soy de confianza, ¿entiendes? No se lo diré a nadie, nada. Dímelo.

En la conversación (10), puede que la causa más probable del tratamiento asimétrico reflejado en las líneas 2 y 6 con la morfología verbal (la desinencia - $z u$ ) de verbos como uztazu y kontatuko banizu, y en la línea 7- sea el tipo de amistad que mantienen Tximista e Itxaso: son amigos, pero no íntimos. Lo curioso en (10) es que, si no son amigos íntimos, lo correcto sería que Tximista utilizara $z u$ para dirigirse a Itxaso, tal y como hace ella. Entonces, esta razón para justificar este uso asimétrico no sería la más adecuada. El caso es que Itxaso, en ninguna otra conversación utiliza $h i$, independientemente de a quién se esté dirigiendo. Así, se podría seguir la hipótesis de que Tximista emplea hi porque Itxaso es su amiga, pero esta hace lo contrario porque en su variedad del euskera no hay lugar para $h i$. Por consiguiente, es difícil catalogar el tipo de relación que están creando en (10), aunque de nuevo, se defiende que $z u$ por parte de Itxaso es un caso más de pronombre no marcado pragmáticamente, en lugar de ser parte de la cortesía negativa.

En cualquier caso, ya se ha mencionado arriba que las conversaciones en (9) y en (10) son representaciones de casos minoritarios en los que hay una relación asimétrica, y que las conversaciones entre amigos están dominadas por un uso recíproco del pronombre, ya sea $h i$ o $z u$.

En resumen, si se establece una comparación entre los usos de los pronombres de segunda persona del singular dentro de la variable de la amistad y en sus respectivas lenguas, se concluye que se crean relaciones interpersonales bastante parecidas en las dos comunidades de habla en las que se centra este estudio. Es evidente que con tú se crea la relación más íntima posible y esto también es posible en euskera tanto con $h i$ como con $z u$-siempre que su uso sea 
simétrico. Finalmente, respecto al uso de los pronombres de manera asimétrica, en ambos idiomas se utiliza el pronombre de la cortesía negativa -usted y $z u$-para dirigirse a amigos que son mayores, y marcar así, distancia y respeto. Sin embargo, se puede declarar que este último caso constituye una minoría no representativa en ambos idiomas.

\section{La Familia}

En cuanto a la variante de las relaciones familiares y hablando primero del español, Sanromán Vilas (2010) descubrió en su estudio en Vigo y en Madrid, que en esta variante existe también una imposición completa del tuteo sobre el pronombre usted. Por ejemplo, entre hermanos existe un uso absoluto de tú (Sanromán Vilas, 2010). Aunque sus resultados muestran que las personas nacidas entre 1910-29 todavía utilizan usted para dirigirse a padres, abuelos, tíos, y suegros, en menos de ochenta años se observa la imposición de tú (Sanromán Vilas, 2010). El estudio que Sampedro Mella (2016) desarrolló en el español centro-norteño destaca que las relaciones familiares también están dominadas por el uso de tú, al tratarse de personas conocidas e íntimas. El estudio en Extremadura de Montero Curiel (2011) desvela de la misma manera que se utiliza tú para dirigirse tanto a familiares mayores como a familiares de edad similar o más jóvenes, y de diferente tipo de relación, como padres y suegros. Los estudios de Montero Curiel (2011) y Pedroviejo Esteruelas (2006), este último en Valladolid, muestran el mismo porcentaje de hablantes que utilizan usted para dirigirse a los abuelos: 14.28\%. También es destacable que alrededor del $80 \%$ de los nacidos entre 1950-69 utilizan el pronombre de la cortesía positiva tú para referirse a sus padres (Sanromán Vilas, 2010). Por tanto, en el español peninsular, a lo largo de los años del siglo XX y finalmente en el XXI se destaca el completo empleo de tú entre familiares, aunque la edad del familiar pueda influir en algunos casos 
minoritarios, a la hora de elegir el pronombre apropiado (Pedroviejo Esteruelas, 2006; Sanromán Vilas, 2010).

En euskera, con el análisis de la serie Goenkale en la Tabla 3, el pronombre hi no ha sido utilizado en ningún caso por las chicas, ya sea de forma recíproca o asimétrica, en cuanto a relaciones familiares se refiere. Este es otro ejemplo más del poco uso de este pronombre por parte de las chicas (Amorrortu, 2003). Por el contrario, los chicos utilizan hi de forma recíproca cuando se trata solamente de hermanos, como en (11).

1 Kandido Kanposantura joateko gai ez eta tabernan geratu ninduan. Andoni iritsi zuan orduan. Handik gutxira hi, eta gero bera. Dios! No fui capaz de ir al cementerio y me quedé en el bar. Entonces llegó Andoni. Al poco tiempo tú, y después él. ¡Dios!

2 German Etzak hire burua gehiago estutu. No te tortures más a ti mismo.

3 Kandido Hil artean neurekin eramango diat oinaze hori. Badakik? Kanposantura joan nahi nian gaur... Olga ikustera. Baina ez diat kemenik izan. Llevaré este mal conmigo hasta que me muera. ¿Lo sabes? Hoy quería ir al cementerio... a ver a Olga. Pero no he tenido fuerzas.

4 German Hago lasai. Ahaztu egin behar duk dena. Estate tranquilo. Tienes que olvidarlo todo.

5 Kandido Minak ez zidak uzten. El dolor no me deja.

6 German Saiatu egin behar duk. Olgak ere horixe nahiko zian: hik gehiago ez sufritzea. Hik ba al hekien Bogarena?

Tienes que intentarlo. Olga también querría eso: que tú no sufrieras más. ¿Tú sabías lo de Boga?

7 Kandido Ez. Aliziaren kontua izan duk.

No. Ha sido cosa de Alizia.

Siendo (11) una conversación representativa entre hermanos de entre todos los que se han recolectado de la mencionada serie, se comprueba que siendo obligatorio el uso de $h i$ entre hermanos en aquellas variedades del euskera en las que se puede utilizar dicho pronombre (Alberdi, 1991; Echeverria, 2003; Trask, 2003), se crea la relación más íntima y solidaria posible en este ambiente familiar, manteniendo la imagen social de ambos interlocutores, como en (11), 
con el uso recíproco del pronombre de la cortesía positiva, como se comprueba en las líneas 1 y

6. Con este uso simétrico del pronombre de la cortesía positiva hi en euskera, estos hermanos no crean ninguna amenaza a la imagen social de su interlocutor. Además, también se comprueba la creación de la relación cercana en (11) con la sinceridad de los hablantes a la hora de contar sus problemas -como en las líneas 1, 3, y 5- y el apoyo que se le ofrece al interlocutor por parte de German -como en las líneas 2, 4, y 6.

También hay conversaciones entre chicos de la familia en las que no existe un uso simétrico de $h i$, como se señala en las Tablas 3 y 4 . En estos casos, la hipótesis que se sigue para justificar este uso asimétrico es la importancia de la diferencia de edad entre los familiares.

Como ejemplos de estas situaciones están la conversación en (12), entre un padre y un hijo, y en (13), una interacción entre un abuelo y un nieto.

$1 \quad$ Abel Eta hik, zer egiten duk hemen? Y tú, ¿qué haces aquí?

2 German Ez... Egia esan, zu hemen ikusi zaitudanetik, gauza bakarra daukat buruan... Zer moduz doa Aketzarena?

No... A decir verdad, desde que te he visto aquí, solo tengo una cosa en la cabeza... ¿Cómo va lo de Aketza?

3 Abel Utzidak niri. Hik zenbat eta gutxiago jakin, hobe niretzat. Déjamelo a mí. Cuanto menos sepas tú, mejor para ti.

4 German Zuk ala badiozu... Si tú lo dices...

5 Abel Korapiloa konponduko nuela agindu nian, ezta? Kito ba. Hala ere, datu gehiago eman beharko dizkidak.

Te prometí que arreglaría el lío, ¿verdad? Pues ya está. Aun así, me tendrás que dar más datos.

6 German Ados, baina arazoak ditut merkantziaren zain daudenekin. De acuerdo, pero tengo problemas con los que están esperando la mercancía.

$1 \quad$ Abel Zer Lukas! Etxean oraindik? ¿Qué Lukas! ¿Todavía en casa?

2 Lukas (Germani telefonotik). Aitonak traste batzuekin laguntzeko eskatu dit eta 
berandutu egin zaigu. Barkatu.

(Por teléfono a German). El abuelo me ha pedido que le ayudara con unas cosas y s eme ha hecho tarde. Perdón.

3 German (Lukasi telefonotik) Ondo da, aitonak eskatu badizu... baina hemen nahi zaitut berehala!

(Por teléfono a Lukas). Está bien, si te lo ha pedido el abuelo... ¡Pero te quiero aquí enseguida!

4 Lukas (Germani telefonotik). Bai, jakina... Oraintxe arte.

(A German por teléfono). Sí, por supuesto... Hasta ahora.

5 Abel Gezurtia beti hankamotz. Hik ez dakik hori?

Al mentiroso se le pilla antes por mentiroso que por cojo. ¿Tú no sabes eso?

6 Lukas Lasai. Gezur txiki bat baino ez da izan.

Tranquilo. No ha sido más que una pequeña mentira.

7 Abel Gizonak erantzukizunez jokatu behar dik. Heldutasunez, Lukas... Un hombre tiene que actuar con responsabilidad. Con madurez, Lukas...

8 Lukas Joder! Ez hasi zu ere! ¡Joder! ¡No empiece usted también!

9 Abel Jokatu ba gizalegez! Ez al haiz pa nire biloba? ¡Pues actúa con educación! ¿No eres mi nieto?

En las conversaciones como (12) y (13), la persona mayor es dirigida con $z u$-en las líneas 2 y 4 en (12), y en la línea 8 en (13)-, y este -el interlocutor mayor- utiliza hi para referirse a su familiar más joven -en las líneas 1 y 3 en (12), y en la línea 5 en (13). Esto hace que la relación que se establece entre los hablantes no sea igualitaria, sino asimétrica, adoptando un estatus social superior por parte del interlocutor mayor. Además, la imagen social del interlocutor mayor está siendo respetada con el empleo del pronombre de la cortesía negativa, mientras que la imagen del más joven puede verse amenazada con el empleo asimétrico del pronombre de la cortesía positiva. De esta forma, los familiares entre los que existe una diferencia de edad, crean una relación más distante, marcando deferencia y respeto hacia el hablante mayor con $z u$.

La diferencia de edad entre familiares, también afecta a las conversaciones entre personas de los dos géneros. No obstante, solo se han encontrado tres casos de asimetría de $h i$ entre familiares que son de sexos contrarios, como en (14), entre un abuelo y una nieta. 


$\begin{array}{ccl}1 & \text { Abel } & \begin{array}{l}\text { Arratsalde on. } \\ \text { Buenas tardes. }\end{array} \\ 2 & \text { Joana } & \begin{array}{l}\text { Aitona! Zer moduz? } \\ \text { iAbuelo! ¿Qué tal está (usted)? }\end{array} \\ 3 & \text { Abel } & \begin{array}{l}\text { Hi hobeto. Pozik ikusten haut. } \\ \text { Tú mejor. Te veo contenta. }\end{array} \\ 4 & \text { Joana } & \begin{array}{l}\text { Bai. Zatoz, lagun bat aurkeztuko dizut. } \\ \text { Sí. Venga, le voy a presentar a un amigo. }\end{array}\end{array}$

Lo que se evidencia con (14) es que los familiares mayores siempre utilizan $h i$-línea 3para referirse a los más jóvenes, en aquellas variedades en las que se da esta forma pronominal. Por tanto, en estas variedades dialectales, no se suelen crear relaciones igualitarias entre familiares de diferente edad (tanto entre padres e hijos, como entre abuelos y nietos): la persona mayor tiende a adquirir -más abajo se explicarán algunas excepciones- un carácter superior por ser tratado con el pronombre de deferencia o respeto -línea 4 con el verbo auxiliar dizut. Se crean así, efectivamente, relaciones de distancia, respeto, y deferencia, entre familiares que no pertenecen a la misma generación (entre padres e hijos, y entre abuelos y nietos), independientemente de si pertenecen o no al mismo sexo.

Siguiendo con el análisis de las conversaciones entre familiares, hay casos de simetría de $h i$ entre familiares que son chico y chica, como en (15), que se trata de dos primos que han tenido una relación muy estrecha debido a que desde pequeños han convivido en el mismo hogar.

\begin{tabular}{ccl}
1 & Joana & $\begin{array}{l}\text { Zertan ari haiz? } \\
\text { ¿Qué estás haciendo? }\end{array}$ \\
2 & Lukas & $\begin{array}{l}\text { 'Harria' falta zaidan! } \\
\text { ¡Me falta la 'piedra'! }\end{array}$ \\
3 & Joana & $\begin{array}{l}\text { Normala! } \\
\text { ¡Normal! }\end{array}$ \\
4 & Lukas & $\begin{array}{l}\text { Ze esan nahi dun? } \\
\text { ¿Qué quieres decir? }\end{array}$ \\
5 & \multirow{2}{*}{ Joana } & $\begin{array}{l}\text { Galtzetan utziko huen. } \\
\text { Te lo dejarías en los pantalones. }\end{array}$
\end{tabular}




$\begin{array}{ccl}6 & \text { Lukas } & \begin{array}{l}\text { Egia! Jode! } \\ \text { ¡Cierto! ¡Jode! } \\ 7\end{array} \text { Joana } \\ & \begin{array}{l}\text { Hik bai buru ustela! } \\ \text { ¡Tú sí que tienes una cabeza podrida! } \\ 8\end{array} \text { Lukas } & \begin{array}{l}\text { Hiri etzain ezer ahazten ala? } \\ \text { ¿A ti no se te olvida nada o qué? }\end{array} \\ 9 & \text { Joana } & \begin{array}{l}\text { Gauza inportanteak ez! } \\ \text { Las cosas importantes, no. }\end{array} \\ 10 & \text { Lukas } & \begin{array}{l}\text { Hi, izan ere, 'lixta' izan! } \\ \text { ¡Es que tú eres muy 'lista'! }\end{array}\end{array}$

La conversación en (15) es un caso ilustrativo para demostrar que las conversaciones con $h i$ simétrico que se han encontrado entre personas de ambos sexos en esta serie y dentro de la variable de la familia, son solo interacciones entre primos, y en ningún caso entre otro tipo de familiares. Puede que esta simetría de $h i$ entre primos y no, por ejemplo, entre hermanos de ambos sexos, esté causado por el hecho de que estos primos mantienen una relación de amistad íntima más allá del ámbito familiar: pertenecen al mismo círculo de amistades aparte de ser de la misma familia. En cualquier caso, en las interacciones como (15), ambos interlocutores utilizan el pronombre de la cortesía positiva de forma recíproca -en las líneas 7 y $10-$ y, por consiguiente, establecen una relación cercana e íntima, con ausencia de actos de amenaza a la imagen social de ambos. De todas formas, debe tenerse en cuenta que tal y como se ha explicado antes en este párrafo, posiblemente la principal razón para que estos interlocutores utilicen este pronombre de forma recíproca sea que son amigos, y este factor tenga más peso que el hecho de pertenecer a una misma familia.

Por lo que respecta al uso recíproco de $z u$, este es el único pronombre que utilizan las familiares que pertenecen al género femenino entre ellas, como en (16) entre una madre y una hija, y en (17) entre dos hermanas. 
1 Ikerne Zer pasatzen da hemen? Ama! Zer duzu hor? ¿Qué pasa aquí? ¡Mamá! ¿Qué tienes ahí?

2 Alizia Ez da ezer. Botila bat puskatu da eta ebaki bat egin dut. Kito, hori da guztia!

No es nada. Se ha roto una botella y me he hecho un corte. ¡Ya está, eso es todo!

3 Ikerne Eskerrak! ¡Menos mal!

4 Alizia Lagundu egin beharko didazue tabernan, nik ezin dut-eta ia ezer egin. Me vais a tener que ayudar en el bar, porque yo no puedo hacer casi nada.

5 Joana Eta Margari? ¿Y Margari?

6 Alizia Margarik ere min hartu du hanka batean. Horregatik dago itxita. Margari también se ha hecho daño en una pierna. Por eso está cerrado.

7 Ikerne Zu ez kezkatu, ama! Guk lagunduko dizugu, ezta, Joana? ¡Tú no te preocupes, mamá! Nosotros te vamos a ayudar, ¿verdad, Joana?

8 Joana Bai, noski. Baina azkar sendatu, e, ama!

9 Alizia Zuk duzu azala, zuk! ¡Vaya piel tienes tú!

1 Ikerne Eta zuk zer egiten duzu hemen? Hau nire gela da! Ospa! ¿Y tú qué haces aquí? ¡Esta es mi habitación! ¡Vete!

2 Naia Argazki albumak hemen daude eta... Barkatu. Los álbumes de fotos están aquí y... Perdona.

3 Ikerne Ez, ez... Barkatu zuk. Ez da zure errua. No, no, perdóname tú. No es tu culpa.

4 Naia Baina haserre zaude. Pero estás enfadada.

5 Ikerne Bai, Joana alu horrek kabreatu egiten nau! ¡Sí, la canalla esa de Joana me ha enfadado!

6 Naia Ezin da hori esan! Amak ez du uzten! ¡No se puede decir eso! ¡Mamá no deja!

7 Ikerne Egia ... ez esan amari. Bale? Zer argazki ari zara ikusten? Cierto... no se lo digas a mamá. ¿Vale? ¿Qué foto estás viendo?

8 Naia Aspaldikoak! Begira hau. Ama eta... aita dira, ez? ¡De hace tiempo! Mira esta. Son mamá y... papá, ¿no?

9 Ikerne Bai, oso pozik daude hemen. Sí, aquí salen muy contentos.

10 Naia Zu txikia zinenean ... aitarekin bizi zineten? ¿Cuando tú eras pequeña... vivíais con papá?

11 Ikerne Jakina! ¡Por supuesto! 
En situaciones como (16) y (17) se crean relaciones simétricas con el uso recíproco de $z u$ -esto se comprueba en las líneas 7 y 9 en (16), y en las líneas 1, 3, y 10 en (17). Esto es un dato significante y diferente respecto a los hombres, ya que en (16) -una interacción que se produce en el bar que regenta la familia- se trata de una madre (Alizia) y de dos hijas (Ikerne y Joana) y por lo tanto existe una diferencia generacional entre las hablantes; pero en (17) -una conversación en la casa familiar- se trata de dos hermanas con una mínima diferencia de edad. Pero en este tipo de conversaciones entre mujeres que pertenecen a una familia, se puede mantener que aun con la utilización de $z u$, se crean relaciones lo más cercanas posibles -igual que ocurría con $h i-$ al utilizar este pronombre pragmáticamente no marcado y, por consiguiente, sin crear ninguna amenaza a la imagen social de los hablantes. En el caso de las mujeres, entonces, no importa tanto la diferencia de edad entre los interlocutores ya que utilizan $z u$ de forma recíproca -en el 100\% de las conversaciones recaudadas entre chicas familiares. Además, hay que considerar que en estos casos no se trata de una estrategia de la cortesía negativa, sino que $z u$ sería comprendido como un pronombre pragmáticamente no marcado por ser el único pronombre que utilizan estas hablantes entre ellas.

Por parte de los chicos, se ha encontrado el uso recíproco de $z u$ tan solo en 16 conversaciones -frente a 36 conversaciones con un uso simétrico de $h{ }^{-}$-, como en (18) entre dos hermanos, y en (19) entre un padre y su hijo.

1 Lukas Unai! Iritsi zara! Lastima... Hemendik aurrera komuna konpartitu beharko dugu.

¡Unai! ¡Has llegado! Pena... A partir de aquí vamos a tener que compartir el baño.

2 Unai Neuk ere maite zaitut! Etorri hona.

¡Yo también te quiero! Ven aquí.

3 (Elkar besarkatzaen dute biek, elkarri bizkarrean kolpe abegitsuak emanez).

(Ambos se dan un abrazo, dando palmadas acogedoras en la espalda del 
otro).

4 Unai Beti bezain itsusi zaude!

¡Estás tan feo como siempre!

5 Lukas Eta zu gizenduta!

¡Y tú has engordado!

6 Unai Faltan bota zaitut!

¡Te he echado de menos!

7 Lukas Ba nik ez. Alde ederreko bakea zu gabe!

8

Pues yo no. ¡Vaya paz sin ti!

(Irri egiten dute biek).

(Ambos se ríen).

1 Lukas Aita! Kaixo, Enriketa!

¡Papá! ¡Hola, Enriketa!

2 Enriketa Egun on, Lukas!

¡Buenos días, Lukas!

3 German Kaixo, seme!

¡Hola, hijo!

4 Lukas Zertan lagunduko dizut?

¿En qué te puedo ayudar?

5 German Eskerrik asko. Baina harritzekoa da zu hain goiz etortzea!

Muchas gracias. ¡Pero es raro que tú hayas venido tan pronto!

6 Lukas Zer ba?

¿Por qué?

7 German Bart zer ordutan etxeratu zaren kontuan hartuta...

Teniendo en cuenta a qué hora llegaste anoche a casa...

En (18) es curioso que utilicen $z u$ entre hermanos de forma recíproca -en las líneas 2 y 4

con los verbos auxiliares zaitut y zaude, y en las líneas 5 y 7 con $z u$ - ya que Lukas en otras

conversaciones utiliza $h i$ dependiendo de la persona a la que se dirige (por ejemplo, con amigos);

no así Unai, que en su variedad del euskera solo utiliza el pronombre $z u{ }^{8}$ Esto puede indicar que

sabiendo Lukas que su hermano no emplea $h i$, quiere crear una relación simétrica con su

hermano a través de $z u$. Esto hace pensar que la utilización de $z u$ por parte de Lukas es una

muestra de cortesía -aunque en este caso no sea un ejemplo de la cortesía negativa- porque él

\footnotetext{
${ }^{8}$ La razón más probable que explique las diferentes variedades que utilizan estos dos hermanos es que no siempre han vivido juntos. De hecho, en gran parte de la octava temporada de la serie Goenkale aquí analizada, Unai se encontraba estudiando en Estados Unidos.
} 
desea establecer una relación simétrica e igualitaria con su hermano. Por su parte, los hablantes de (19) utilizan $h i$ en otro tipo de variantes, por ejemplo, Lukas con sus amigos y German con su hermano. Sería lógico pensar por tanto que German debería utilizar $h i$ para dirigirse a su hijo, y consecuentemente, Lukas debería utilizar $z u$ para referirse a su padre. Entonces, se comprueba que el padre -German- quiere establecer una relación simétrica con su hijo -Lukas-, y como el hijo no puede emplear $h i$ para dirigirse a su padre, es el padre el que adopta el pronombre $z u$. Esta interacción evidencia de la forma más clara posible que un interlocutor supuestamente superior, aboga por crear una relación igualitaria y solidaria -en la línea 4 con el verbo auxiliar dizut y en la línea 5 con el pronombre $z u$. En ambas conversaciones, se observa una actitud cooperativa por parte de todos los hablantes ya que con el uso recíproco de $z u$, respetan su propia imagen social y también la de sus interlocutores, y se comprueba que crean relaciones íntimas y, sobre todo, solidarias entre ellos aun utilizando el pronombre que en otros contextos es parte de las estrategias de la cortesía negativa.

También, con la comparación de la Tabla 3 y 4, está claro que el principal pronombre que se utiliza de forma simétrica en las conversaciones entre familiares de sexos opuestos es $z u$-en 71 conversaciones-, como en (20) entre un suegro y su nuera, y en (21) entre un padre y su hija.

1 Abel Zer gertatzen da hemen? ¿Qué ocurre aquí?

2 Alizia Ezin dudala asmatu neska honekin! ¡Que no sé qué hacer con esta chica!

3 Abel Zer nahi duzu? Ahaztu egin al zaizu zeu ere gaztea izan zinela? ¿Qué quieres? ¿Se te ha olvidado que tú también fuiste joven?

4 Alizia Hasi zu gainera aurpegia ateratzen! ¡Encima tú empieza a defenderla!

5 Joana (Abeli). Amari kasurik ere ez. Histeriko hutsa da! (A Abel). A mamá no le haga ni caso. ¡Es una histérica!

6 Alizia Nondik atera ote du ume honek jenio hori? ¿De dónde habrá sacado esta chica ese genio?

7 Abel Eta zuk galdetzen duzu hori? Alizia... ¿Y tú preguntas eso? Alizia... 
8 Alizia Bale. Antzekoak gara biok, odolberoak. Eta agian horrexegatik gaude beti txakurra eta katua bezala.

Vale. Las dos somos parecidas, de sangre caliente. Y a lo mejor por eso estamos siempre como el perro y el gato.

$(21)$

1 Kandido Sutearen kontuan nire babes osoa duzula jakitea nahi dut.

Quiero que sepas que en el tema del incendio tienes todo mi apoyo.

2 Joana Nikez dut zure babesa behar!

¡Yo no necesito tu ayuda!

3 Kandido Joana, nik badut konfiantza zugan, zergatik etzara zu ere nirekin saiatzen?

4 Joana Nahi nuke, baina ezin dut.

Me gustaría, pero no puedo.

5 Kandido Gauzak ahalik eta ondoen egiten ahalegintzen naiz.

Solo intento hacer las cosas lo mejor posible.

6 Joana Baliteke, baina zu behin ondo portatuagatik, ez ditut ahaztuko hamar urte luze hauek.

Puede ser, pero porque te comportes bien una vez, no voy a olvidar estos diez años largos.

7 Kandido Jabetzen naiz, baina ahaztea da aurrera egiteko bide bakarra.

Ya me doy cuenta, pero olvidar es el único camino para seguir adelante.

En (20), como se trata de personas de diferentes sexos y que no mantienen una relación de padre e hija, sino que son suegro -Abel-y nuera -Alizia-, no se encuentra la utilización de $h i$ por parte de ninguno de los dos hablantes - de acuerdo con los usos establecidos de este pronombre-(Alberdi, 1991; Trask, 2003). Por consiguiente, (20) podría categorizarse como una relación de respeto, distancia, y deferencia, y en este caso, la interpretación de $z u$-en las líneas 4 y 7- como pronombre de la cortesía negativa sería correcta, ya que pueden estar creando una relación de distancia. En (21) también hay un trato simétrico de $z u$ entre el padre y la hija, como se ve en las líneas 3 y 6 . Pero en (21), Kandido es el padre y se supone que podría dirigirse a su hija Joana con $h i$ en lugar de $z u$, aunque es igualmente cierto que, tal y como se introdujo en el Capítulo II, no es tan común la utilización de $h i$ entre personas que no son del mismo sexo (Alberdi, 1991; Echeverria, 2003; Trask, 2003). Así en (21), el padre es el que principalmente 
defiende una relación igualitaria y solidaria con su hija, tal y como ocurría anteriormente en (19) entre un padre y su hijo. Finalmente, tanto en (20) como en (21), no se atisba ningún acto de amenaza a la imagen social de los interlocutores con el uso simétrico del pronombre $z u$.

Teniendo en cuenta estos ejemplos y sus análisis, y si se comparan las relaciones sociales que se crean en el ámbito familiar a través de los usos de los respectivos pronombres en el español de la Península Ibérica y en euskera, se concluye que existen diferencias entre ambas lenguas, principalmente debido a la diferencia generacional entre los interlocutores. En el español peninsular, una más que mayoría de las relaciones familiares se produce con el pronombre tú, y los hablantes que todavía utilizan usted para referirse a sus abuelos, constituyen una minoría. En euskera, la edad es la causa principal que guía la elección apropiada del pronombre. En las conversaciones con personas mayores, por ejemplo, con padres y abuelos, las personas jóvenes nunca utilizan $h i$, sino que siempre utilizan $z u$-a diferencia del español peninsular que sí se utiliza tú entre padres e hijos. Además, en estos casos, se ha visto que suelen crearse relaciones asimétricas, manteniendo por lo menos la imagen social del interlocutor superior por utilizar el pronombre que es parte de las estrategias de la cortesía negativa. No obstante, algunos padres, como en (19) y (21), se decantan por crear relaciones solidarias e igualitarias con sus hijos/hijas. Esto demuestra que la diferencia de edad es un factor fundamental a la hora de seleccionar el pronombre apropiado en las conversaciones entre familiares, pero que, en algunas conversaciones minoritarias entre padres e hijos, también se observa la creación de relaciones iguales y solidarias aun cuando existe diferencia obvia de edad entre ellos. Es destacable de igual manera, que las chicas familiares solo han utilizado $z u$, adquiriendo este el sentido del pronombre pragmáticamente no marcado. Consecuentemente, en euskera, se crean relaciones de igualdad entre parientes, pero es igualmente cierto que, si existe 
una diferencia de edad destacada, la relación interpersonal que se creará, será probablemente de asimetría con el empleo del pronombre de la cortesía negativa.

\section{Asimetría de Poder Social}

Por lo que respecta al uso del español en relaciones de poder asimétrico, Sanromán Vilas (2010) informa que el $80 \%$ de los hablantes de Vigo que participaron en su estudio utilizan usted para dirigirse a personas con las que mantienen una distancia de poder y de estatus, aunque a partir de la generación de 1970-80, el porcentaje desciende hasta el 65\% de los hablantes del estudio. Los resultados de su estudio en Madrid no son exactos al de los de Vigo, pero sí muy similares (Sanromán Vilas, 2010). Respecto al pronombre utilizado por el superior para dirigirse al inferior, tú es el más preferido tanto en Vigo como en Madrid (Sanromán Vilas, 2010). Con su estudio del español centro-norteño, Sampedro Mella (2016) justificó que en las conversaciones marcadas por una diferencia de poder en el que uno es superior al otro, hay una gran probabilidad de que se produzca un trato asimétrico de los pronombres de segunda persona del singular del español peninsular. De hecho, Sampedro Mella (2016) revela que, en muchos de estos casos, los hablantes suelen dudar de la elección del pronombre apropiado, debido principalmente a la falta de información sobre el interlocutor, lo cual demuestra a su vez, el uso cada vez mayor del tuteo en este tipo de situaciones. Igualmente, el género de los hablantes es un factor a considerar dentro de esta variable: Sampedro Mella (2016) desvela que en este tipo de relaciones asimétricas los usos de los pronombres de segunda persona del singular en la Península Ibérica plasman el empleo de tú por parte de los hombres hacia las mujeres, mientras que usted por parte de las mujeres hacia los hombres. Montero Curiel (2011) -con su estudio en Extremadura- y Pedroviejo Esteruelas (2006) - con su análisis del uso de los pronombres de 
segunda persona del singular en Valladolid-ofrecen tres ámbitos para ilustrar las conversaciones marcadas por la distancia y el poder social: (i) para dirigirse a los profesores que conocen de forma superficial, los hablantes utilizan más usted que tú, aunque la decisión definitiva está relacionada con la accesibilidad del profesor, es decir, dependiendo de si el profesor ofrece la oportunidad de establecer una relación más cercana o distante -los resultados del estudio de Sanromán Vilas (2010) en Vigo y en Madrid están en concordancia con esta aseveración-; (ii) para hablar con los trabajadores de un banco, se utiliza usted, exceptuando algún caso con el pronombre tú; y finalmente, (iii) para dirigirse a camareros, los hablantes más jóvenes utilizan tú para tratar a los camareros que pertenecen a una generación similar a la suya, pero en cambio, usted predomina para referirse a camareros que ya hayan pasado el umbral de los cuarenta años.

En el caso del euskera, las conversaciones marcadas por las relaciones de asimetría de poder y de estatus social están dominadas por un uso recíproco de $z u$ : se han obtenido 43 conversaciones (de un total de 45 casos) que siguen esta línea, las cuales se muestran en la Tabla 4. Tan solo se han encontrado 2 conversaciones que no siguen esta regla, las cuales muestran un uso asimétrico de los pronombres en euskera entre chicos. Sin embargo, como son solo 2 excepciones frente a 43 conversaciones con el mismo patrón, aunque con diferentes elementos contextuales, no se incluye su análisis.

Volviendo al uso recíproco de $z u$ dentro de esta variante, uno de los casos más frecuentes que se han observado en la octava temporada de la serie Goenkale, con la obtención de los diálogos a través del corpus Lexikoaren Behatokiaren Corpusa es en el contexto del trabajo, como en (22) y en (23).

1 Alizia Nirekin nahi zaitut, Margari. Eta ahal dela oraintxe bertatik gainera... Te quiero conmigo, Margari. Y a poder ser desde ahora mismo además...

2 Margari Tira... zuk hala nahi baduzu... 

Bueno... si tú lo quieres así...
3 Alizia Bai, Margari. Nahita ere ez dut zu bezalakorik aurkituko. Zer diozu? Sí, Margari. Aun queriendo no voy a encontrar nadie como tú. ¿Qué dices?
4 Margari Zure aginduetara nagoela, etxekoandre!
¡Que estoy a tu servicio, señora!

\footnotetext{
1 Enriketa Erretiroko paperak iritsi zaizkit.

Me han llegado los papeles de la jubilación.

2 German Ez duzu atzera egingo orduan?

¿No vas a echarte para atrás entonces?

3 Enriketa Ez, erabakita dago.

No, está decidido.

4 German Baina ez dituzu 60 urte oraindik eta!

¡Pero si todavía no tienes 60 años!

5 Enriketa Esan nizun; senarra erretiratu zait eta urte hauek aprobetxatu nahi ditugu.

Te lo dije; mi marido se ha jubilado y queremos aprovechar estos años.

6 German Eta zer egin behar dut zu gabe?

¿Y qué voy a hacer sin ti?

7 Enriketa Topatuko duzu beste norbait. Ya encontrarás a alguien.

8 German Nik zu maite zaitut, ordea. Zu bakarrik. Yo te quiero a ti, sin embargo. Solo a ti.

9 Enriketa Ai zu, bistan da, bai, Lukasen aita zarela! German, gizonak emakumea behar du ondoan. Noiz ezkondu behar duzu berriro?

¡Oye tú, está a la vista, sí, que eres el padre de Lukas! German, un hombre necesita a una mujer a su lado. ¿Cuándo te vas a casar otra vez?

10 German Enriketa... gaur ez. Gaur ez nago sermoietarako.

Enriketa... hoy no. Hoy no estoy para sermones.
}

En (22), la conversación se produce entre dos mujeres, en la que Alizia es la jefa y

Margari la empleada. Tal y como se observa en las líneas 2 y 3, ambas interlocutoras utilizan el pronombre de la cortesía negativa de forma recíproca. De forma similar, en (23), German es el jefe y Enriketa es su empleada. En (23) también se utiliza zu de forma simétrica, como en las líneas 6, 7, y 8. Las conversaciones en (22) y (23) son así casos representativos de todos los recaudados para el presente trabajo, para demostrar que, en las conversaciones entre personas separadas por una asimetría de poder, se crean relaciones de respeto, independientemente de si se 
trata de hablantes del mismo sexo o del sexo contrario, aunque teniendo en cuenta el nivel de conocimiento de los hablantes en (22) y en (23), el uso de $z u$ se interpreta como el uso del pronombre no marcado pragmáticamente. Es decir, los hablantes de (22) y (23) crean relaciones respetuosas, pero no distantes y deferentes tal y como puede ocurrir en el español. Además, teniendo en cuenta que las interlocutoras que pertenecen al género femenino en (22) y (23) utilizan solo $z u$ en cualquier variable independientemente de si se refieren a la familia, amigos, o pareja -como se comprueba en las conversaciones obtenidas para el análisis- se puede defender que $z u$ en estas conversaciones puede ser percibido simplemente como un pronombre igualitario. En cambio, en (23) sería absolutamente correcto que German utilizara hi para dirigirse a su empleada de forma asimétrica, aunque es igualmente cierto que, siguiendo las normas de uso de los pronombres de segunda persona del singular del euskera, no es tan típico encontrar un trato asimétrico entre personas de diferentes sexos (Alberdi, 1991; Trask, 2003). Entonces, lo importante en estos casos es que hay que tener en cuenta el nivel de conocimiento entre los interlocutores en (22) y (23), y efectivamente, con el análisis de todas sus conversaciones se puede comprobar que tienen un grado alto de conocimiento y confianza mutua.

Dentro de Goenkale, otro contexto común para ilustrar la diferencia de estatus y poder, son las conversaciones que se producen entre los agentes de la policía en el cuartel de la Ertzaintza ${ }^{9}$, como se ejemplifica en (24).

1 Andoni Ezin duzu zure kontura jardun. Guztion gainetik zabiltza! No puedes actuar por tu cuenta. ¡Estás actuando por encima de todos!

2 Nekane Eta zer arraio egin behar nuen? Milenaren bilaketa bertan behera itxi gura dute! ¿Y qué demonios tenía que hacer? ¡Quieren abandonar la búsqueda de Milena!

3 Andoni Hara, badakit gogorra dela, eta txarto pasatzen zabiltzala...

\footnotetext{
${ }^{9}$ Es la policía autónoma del País Vasco que depende de su gobierno.
} 

Mira, sé que es duro, y que lo estás pasando mal..
4 Nekane Pentsa orduan zelan dauden Koldo eta Leonor!
5 Andoni Jabetzen naiz. Asko sufritzen dabiltza!
Me doy cuenta. ¡Están sufriendo mucho!
6 Nekane Zuk uste baino gehiago!
¡Más de lo que tú te piensas!
7 Andoni Baina ipini zaitez nire lekuan: neuri be presio handia egiten didate goitik.
Pero ponte en mi situación: a mí también me hacen mucha presión desde arriba.
8 Nekane Jakina!
¡Por supuesto!
9 Andoni Sekulakoak esaten dizkidate zuk saltsaren bat antolatzen duzun aldiro! ¡Me dicen cosas impresionantes cada vez que tú organizas una!
10 Nekane Niri bost zer esaten dizuten!
¡A mí no me importa lo que te digan!

En las conversaciones como (24), Nekane es la comisaria del cuartel y Andoni es su subordinado. En todas sus conversaciones, al igual que con otros agentes inferiores, Nekane utiliza $z u$, y también recibe este tratamiento supuestamente deferencial por parte de Andoni, o del resto de agentes, como en las líneas 6 y 9. Por lo tanto, en un principio se podría decir que se crean relaciones marcadas por la deferencia, la distancia y el respeto, pero en realidad, se trata del uso del pronombre pragmáticamente no marcado, existiendo una distancia mínima entre los interlocutores por el nivel de conocimiento que existe entre estos trabajadores, y con una ausencia de amenazas a la imagen social de todos los interlocutores.

El último contexto que se incluye como ejemplo dentro de esta variable, son las conversaciones entre alumnos y profesores, como en (25), en el que Kathy es la profesora de interpretación, e Itxaso su alumna.
1 Kathy Pentsa zure mutila dela!
2 ¡Piensa que es tu chico! (Itxaso gero eta sueltoago). (Itxaso cada vez más suelta).
3 Itxaso Ui, horixe bai dela zaila! 


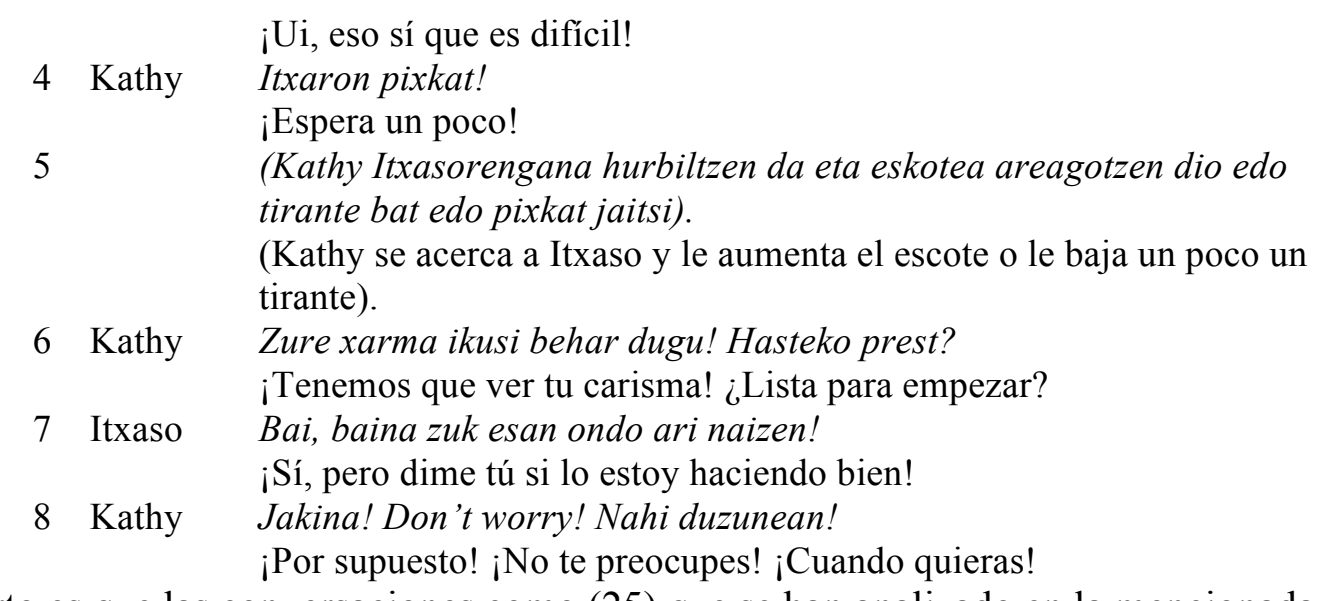

Lo cierto es que las conversaciones como (25) que se han analizado en la mencionada serie, no pertenecen al ámbito académico más formal, como, por ejemplo, un instituto o una universidad, sino que se trata de una academia de interpretación en la que profesorado y alumnado mantienen una relación cercana y estrecha. Aun y con todo, el único pronombre que se utiliza en este tipo de contextos es $z u$ de manera simétrica, como en las líneas 1 y 6 -el pronombre posesivo zure-, y en la línea 7 en (25). En este tipo de contextos también afecta la ambigüedad a la hora de interpretar $z u$ como cortesía negativa -creando así una relación distante y deferencial- o como un pronombre pragmáticamente no marcado -creando de esta forma una relación más cercana y solidaria. De nuevo, el nivel de conocimiento, y sobre todo la confianza, han jugado un papel fundamental a la hora de interpretar $z u$ como pronombre pragmáticamente no marcado, y es que de sus conversaciones se extrae que la profesora y la alumna mantienen una relación cercana y relativamente íntima, porque por ejemplo intercambian experiencias personales y, de hecho, la profesora -Kathy- es un apoyo fundamental para la alumna -Itxasopara seguir adelante con su sueño de ser artista. Finalmente, también ha influido el factor de que $z u$ es el único pronombre que utilizan ambas interlocutoras sin importar las circunstancias de los contextos particulares.

En lo que a esta variable respecta, y a la hora de establecer una comparación de los usos de los pronombres de segunda persona del singular entre el español peninsular y el euskera, se 
debe mencionar que, en el español de la Península Ibérica, en las conversaciones caracterizadas por una relación de distancia y de poder social, se suele utilizar mayormente usted, como parte de la cortesía negativa. En euskera, por su parte, se puede observar que este tipo de conversaciones están dominadas por un uso simétrico de $z u$ (solo se han obtenido dos conversaciones que rompen con la línea general de esta regla). Este uso de $z u$ no ha sido interpretado, como se ha demostrado con los ejemplos introducidos arriba, como una estrategia de la cortesía negativa, sino como un recurso lingüístico que tienen los hablantes para utilizarlo como un pronombre pragmáticamente no marcado. Así, en euskera, en las conversaciones con asimetría de poder social, se crean relaciones de respeto, pero no tan marcadas por la distancia entre los hablantes, debido sobre todo al nivel de confianza y conocimiento que existe entre los hablantes. 


\section{CAPÍTULO V: DISCUSIÓN Y CONCLUSIONES}

El objetivo del presente estudio ha sido realizar una comparación de la creación de relaciones interpersonales a través de los usos de los pronombres de segunda persona del singular en el español peninsular y en euskera, ya que, siendo dos lenguas vecinas, aunque no con el mismo origen, no se han realizado este tipo de estudios comparativos hasta ahora dentro del área de la pragmática intercultural. Como se ha visto arriba, para poder realizar la mencionada comparación de manera satisfactoria, se han utilizado los conceptos de la teoría de la cortesía de Brown y Levinson $(1978,1987)$ como método de análisis. Así, ha quedado demostrado que en el español de la Península Ibérica en la mayoría de los casos se crean relaciones igualitarias e íntimas con el uso simétrico del pronombre tú, mientras que, en euskera, la mayoría de los hablantes hacen uso del pronombre pragmáticamente no marcado $z u$ debido a las restricciones asociadas al uso de hi. Aun y con todo, también se ha observado un uso simétrico de hi de forma extendida entre los hablantes, demostrando que el factor de la diferencia generacional es fundamental a la hora de elegir el pronombre adecuado en euskera. De todas formas, en el presente capítulo se hará referencia a cada una de las preguntas de investigación que se plantearon al principio de este estudio, para así poder extraer más conclusiones concretas de la comparación del español peninsular y el euskera.

En cuanto a la primera pregunta de investigación -referente a los ámbitos en los que se usa cada pronombre en su respectiva lengua- en el análisis se ha visto reflejado que en el español peninsular tú es el pronombre más utilizado, mientras que $z u$ es el más popular en euskera. Efectivamente, tú se utiliza de forma simétrica en las relaciones de pareja, entre amigos, y también entre familiares -en estas dos últimas variantes, en algunos casos los hablantes se decantan por la utilización de usted, sobre todo si existe alguna diferencia reseñable de edad. En 
la variable restante -la asimetría de poder social- parece que lo más usual es el uso asimétrico de los pronombres: tú por parte del superior y usted por parte del inferior.

En euskera, por su parte, el análisis de la serie de televisión ha evidenciado que tal y como establecían los expertos citados en el Capítulo II, las parejas no emplean hi entre ellos, sino $z u$ de forma simétrica. Solo 4 conversaciones -entre una pareja de chicos-rompen con esta regla, lo cual constituye un número insuficiente para poder extraer conclusiones absolutas. Es decir, lo que sí se puede concluir es que con los datos obtenidos por Goenkale, y de acuerdo con los usos establecidos de los pronombres de segunda persona del singular en el Capítulo II, es poco común utilizar $h i$ entre las parejas. En las otras variables, los resultados no son tan simples y, de hecho, es necesario añadir más características específicas para concluir en qué situaciones o contextos se utiliza $h i$ o $z u$.

En las conversaciones entre amigos, los chicos usaron más el pronombre hi que $z u$ entre personas de su mismo sexo -que las chicas entre ellas- de manera recíproca. Lo destacable de esta variante es que, aunque se suponga que no es tan frecuente la utilización de $h i$ entre personas que mantienen una amistad pero que pertenecen a sexos opuestos (Alberdi, 1991; Trask, 2003), las conversaciones obtenidas para este análisis muestran un uso bastante asiduo de hi de manera simétrica ( 42 conversaciones con $h i$, frente a 7 conversaciones con $z u$ ). Puede ser que esta oposición en los resultados con los usos establecidos de los pronombres se deba a un cambio generacional -los 42 casos se producen entre hablantes jóvenes-aunque aquí no se tienen datos suficientes para apoyar esta teoría. Además, la afirmación de Alberdi (1991) y Trask (2003) no se comprobó con ningún estudio, así que se podría defender que su afirmación no es del todo correcta. Otro factor a considerar es que los 42 casos son producto de las conversaciones preparadas para una serie -en este caso Goenkale- y no de conversaciones naturales y 
espontáneas, pudiendo existir una diferencia entre las dos. En cualquier caso, las conversaciones entre amigos están dominados por el uso simétrico del pronombre de segunda persona del singular, ya sea $h i$ o $z u$. Por último, los casos de asimetría en las conversaciones entre amigos son muy escasos con lo que no se pueden elaborar conclusiones exactas sobre esta comunidad de habla, pero lo que sí se puede afirmar es que en la mayoría de los casos esta falta de reciprocidad está causada por una diferencia remarcable de edad entre los hablantes.

Dentro de la variable de la familia en euskera lo destacable en un principio es que las chicas no hicieron uso de $h i$ entre ellas en ninguna conversación analizada. Este pronombre se utiliza de forma recíproca entre hermanos. En las conversaciones entre hombres de la misma familia que están marcadas por una diferencia de edad existe -exceptuando conversaciones minoritarias con $z u$ recíproco entre hermanos, y entre padre e hijo-asimetría de pronombres ya que el mayor utiliza $h i$, mientras que él es referido por el joven con $z u$. Por último, el uso simétrico de $z u$ dentro de una familia se produce entre las chicas y entre hablantes de sexos opuestos -el uso recíproco de $h i$ entre familiares de sexos contrarios se ha dado solamente entre dos primos que viven juntos desde su infancia, pero no entre ningún otro familiar, haciendo que estas conversaciones no puedan tomarse como representativas para las conclusiones.

La última variable establecida es la asimetría de poder social y en estas conversaciones en euskera, $z u$ es el pronombre que se utiliza en todas las interacciones -solo hay 2 excepciones, las cuales no son suficientes para rebatir esta regla-, independientemente de si son conversaciones entre superiores y subordinados -por ejemplo, en el bar, en una empresa dedicada a la pesca, en el cuartel de la policía, o entre profesora y alumna- o de si pertenecen o no al mismo sexo.

En lo referente a la segunda pregunta de investigación, el significado implícito que se vislumbra en el español peninsular con el uso mayoritario del pronombre de la cortesía positiva 
tú de manera recíproca en ámbitos como la pareja, la amistad, y la familia es la de la intimidad, cercanía, y solidaridad, creando de esta forma las relaciones más cercanas posibles entre los hablantes, probablemente con usencia de amenazas a la imagen social de los interlocutores por utilizar el mismo pronombre ambas partes. No es este el caso de las conversaciones que se producen dentro de la variable de la asimetría de poder social en el español peninsular. Como se indicó antes, en estas conversaciones sobresale el uso de usted por parte del inferior, y tú por parte del superior. Las implicaciones de esta asimetría son principalmente el establecimiento de una relación distante y deferente. De hecho, el hablante que utiliza tú marca su superioridad frente al interlocutor con posibles amenazas a la imagen social del oyente, mientras que el participante que utiliza usted marca cortesía y respeto a la imagen social de su interlocutor.

En euskera, es evidente que en las relaciones de pareja con el uso simétrico del pronombre $z u$-en este caso considerado como pronombre pragmáticamente no marcado en lugar de como pronombre de la cortesía negativa- implican un significado de igualdad. De este modo los hablantes del euskera que sean parejas pueden crear relaciones íntimas, cercanas y solidarias, supuestamente respetando la imagen social de sus interlocutores por el hecho de utilizar el mismo pronombre de forma mutua, aunque siendo $z u$ un pronombre neutral en estos casos, los hablantes tendrán que hacer uso de otras características lingüísticas como el uso del vocabulario íntimo para evidenciar dicha solidaridad y cercanía.

Por otro lado, las conversaciones entre amigos en euskera también muestran una creación de relaciones interpersonales basada en la cercanía y en la reciprocidad debido a que en estas conversaciones el uso de los pronombres es recíproco -ya sea $h i$, normalmente entre hombres, o $z u$, entendido aquí como pronombre no marcado pragmáticamente en lugar de como pronombre de la cortesía negativa. Se ha visto que en algunas conversaciones - minoritarias- entre amigos 
puede haber un uso no recíproco de los pronombres causado por la diferencia de edad entre los hablantes. En estos casos, se puede argumentar que no se crean relaciones tan cercanas como con el empleo mutuo de los mismos pronombres ya que, aunque se trate de dos amigos que se conocen perfectamente, la persona que utiliza $z u$ adquiere una identidad inferior a la de su interlocutor, quien utiliza $h i$. Por tanto, el inferior respeta la imagen de su interlocutor marcando una relación de respeto y distancia con el pronombre de la cortesía negativa -zu-, mientras que el superior puede amenazar la imagen de su interlocutor con el pronombre de la cortesía positiva $-h i-$, tal y como podía ocurrir en alguna conversación entre Andoni y Abel, de acuerdo con lo que se ha ilustrado en el capítulo anterior.

Entre familiares que mantienen conversaciones en euskera, el análisis es más complicado. Para empezar, entre hermanos se crean las relaciones más solidarias, íntimas, y cercanas posibles marcados por la camaradería, por el hecho de utilizar el pronombre de la cortesía positiva de manera simétrica. Algo similar ocurre entre las chicas familiares y entre parientes del sexo contrario, lo cual es el resultado de emplear siempre $z u$ de forma recíproca. Efectivamente, entre las chicas se crean relaciones simétricas e igualitarias porque en este caso $z u$ tampoco se interpreta como un pronombre de la cortesía negativa, sino como pronombre pragmáticamente no marcado debido a que es el único pronombre que utilizan ellas. Pero en su caso, tendrán que utilizar otros recursos lingüísticos para evidenciar que existe una cercanía y una confianza determinada entre ellas. Esto contrasta con las relaciones que se crean entre familiares con una diferencia de edad destacable, como en las conversaciones entre padres e hijos, y entre abuelos y nietos. En estos casos, los familiares mayores adquieren una identidad superior frente a los menores $\mathrm{y}$, por tanto, se crean relaciones de distancia en un contexto que a priori puede ser catalogado como íntimo. De hecho, al emplear $h i$ los mayores en referencia a los menores, los 
primeros amenazan la imagen social de sus interlocutores, mientras que los segundos - los menores- respetan la imagen social de sus familiares mayores con $z u$, señalando distancia, cortesía, y respeto. Es curioso mencionar que, en algunas conversaciones -pudiendo ser categorizadas como excepciones- entre hermanos, y entre padres e hijos se descubrió el uso de $z u$ de forma recíproca, cuando lo previsible era un uso asimétrico. Entre estos hermanos, $z u$ se entiende como pronombre pragmáticamente no marcado, pero entre padres e hijos se entiende como el acercamiento de los mayores a los menores con la supuesta intención de crear relaciones igualitarias, en lugar de relaciones marcadas por la distancia y el respeto. Es decir, este fenómeno que se ha observado en casos mínimos puede ser entendido como la inclinación de los participantes hacia la reciprocidad y la simetría usando el pronombre pragmáticamente no marcado $z u$, debido a que el uso recíproco de $h i$ no sería apropiado.

Por su parte, en cuanto a las implicaciones y la creación de relaciones interpersonales dentro de la variante de la asimetría de poder social, con la utilización del pronombre $z u$, se podría decir que, formando este parte de la cortesía negativa, se crean relaciones distantes y respetuosas. Sin embargo, en el análisis que se ha realizado previamente en el Capítulo IV se ha demostrado que realmente en este caso $z u$ no tiene por qué ser interpretado como una estrategia de la cortesía negativa, sino como un pronombre pragmáticamente no marcado, causado por el nivel de conocimiento alto de los personajes de la serie que tienen conversaciones clasificadas en esta variante, y también por ser el único pronombre que utilizan las chicas de estas conversaciones en cualquier situación. Aun así, es igualmente verídico que en ninguna de estas conversaciones la utilización simétrica de $h i$ sería aceptable, lo cual se respeta en las interacciones analizadas. Todo esto indica que en la mayoría de los casos los hablantes del euskera optan por la simetría entre los interlocutores, y que, por esta razón, en los contextos 
conversacionales en los que el uso de $h i$ no es aceptable, los hablantes hacen uso de $z u$ como pronombre no marcado pragmáticamente. La conclusión de este apartado, entonces, sería que en las conversaciones en euskera el concepto de simetría parece jugar un papel fundamental -más que la cortesía negativa- a la hora de explicar los usos de $z u$ y las relaciones que se establecen mediante su uso. Por esto, teniendo en mente estos argumentos, se podría sugerir la incorporación de otra categoría a la hora de interpretar los pronombres del euskera en comparación con sus lenguas romances vecinas. En realidad, esta categoría sería un matiz a la interpretación del pronombre $z u$ como no marcado pragmáticamente, la cual serviría para clasificar este pronombre entre los pronombres de cortesía positiva y negativa de las lenguas romances, ya que en un principio en las conversaciones de asimetría de poder marca deferencia y respeto, pero no tan fuertemente como usted en español. Esto es algo que ha sido apoyado con los ejemplos obtenidos de Goenkale para este trabajo, pero sería conveniente recoger datos orales de conversaciones espontáneas para comprobar este uso de $z u$ en contextos marcados por la asimetría de poder social.

Con todo lo aquí expuesto, y en relación a la tercera pregunta de investigación que se centra en las similitudes y diferencias entre el español peninsular y el euskera acerca de la creación de relaciones personales a través del empleo de sus correspondientes pronombres de segunda persona del singular, lo que aporta este estudio, en primer lugar, es que entre las parejas se crean relaciones idénticas en cuanto a simetría, con el uso recíproco de tú en el español peninsular $\mathrm{y}, z u$-como pronombre no marcado pragmáticamente- en euskera. En segundo lugar, la diferencia en las conversaciones entre parejas en español y en euskera recae en que con el uso recíproco de tú en español los hablantes crean relaciones íntimas, cercanas, y solidarias; mientras que, en euskera, los hablantes tendrán que hacer uso de otros recursos lingüísticos -como el uso 
de vocabulario íntimo, como cariño, o el nivel de confianza- ya que utilizan $z u$ de forma recíproca, pero con valor de pronombre pragmáticamente no marcado.

En las conversaciones entre amigos, se establecen, de forma similar al de las parejas, relaciones solidarias, igualitarias, y con ausencia de amenazas a la imagen social de cada interlocutor, ya que predomina el uso simétrico de tú en el español de la Península Ibérica, y en euskera, $h i$ entre los chicos y zu entre las chicas. Hay que destacar también que como en español a veces los hablantes utilizan los pronombres de forma asimétrica entre amigos que pertenecen a diferentes generaciones, en euskera se han encontrado casos semejantes. En cualquier caso, estos casos de asimetría, tanto en el español peninsular como en euskera, constituyen una minoría frente al uso recíproco de los pronombres de la cortesía positiva, y también del pronombre pragmáticamente no marcado en el caso del euskera.

Si se compara ahora la tercera variable -las conversaciones producidas entre familiaresse observarán algunas diferencias entre el español de la Península y el euskera. En español, en una más que mayoría de los casos todos los hablantes suelen utilizar tú de forma recíproca, creando relaciones solidarias e íntimas, exceptuando algunos casos minoritarios entre personas con diferentes edades -aunque en las generaciones más recientes sobresale tú frente a usted incluso entre personas de distintas generaciones. En euskera, solo se crean relaciones íntimas y solidarias siempre que no se trate de padres e hijos y abuelos y nietos. En estos dos últimos casos, no se da opción en ningún caso a la simetría, estableciendo siempre y obligatoriamente, relaciones de distancia y de respeto entre ellos. Solamente se han encontrado excepciones por parte de jóvenes que utilizan $z u$ de forma simétrica entre padres e hijos, cuando estos padres utilizan $h i$ en otros contextos: esto se puede interpretar como el apoyo a la creación de relaciones solidarias a través del pronombre no marcado. 
Por último, la comparación entre el español peninsular y el euskera sobre las conversaciones marcadas por una asimetría de poder social, revela que en el primer idioma mencionado destaca el uso asimétrico de los pronombres de segunda persona del singular, creando así relaciones de distancia y respeto, mientras que en euskera se utiliza $z u$ como pronombre no marcado pragmáticamente de forma simétrica, creando en consecuencia relaciones personales que tienen características de respeto pero también de solidaridad con cierto grado de cercanía. Por lo tanto, este tipo de conversaciones en euskera tienden a ser más cercanas que las del español peninsular.

Finalmente, con todo el trabajo aquí desarrollado, ha quedado clara la comparación de creación de relaciones personales en cada variable. Se ha podido comprobar que la utilización del pronombre no marcado pragmáticamente en euskera es bastante común, lo cual facilita a los hablantes crear relaciones solidarias e íntimas al no ser utilizado siempre como una estrategia de la cortesía negativa. De hecho, $z u$ como pronombre de la cortesía negativa se utiliza, por lo general, solamente entre padres e hijo, y abuelos y nietos. Sin embargo, la línea entre la cortesía negativa y la ausencia de una marca pragmática es muy delgada, y hay que analizar cada situación. Incluso, con la comparación realizada se evidencia que en la mayoría de los casos parejas, amigos, y familia- en ambos idiomas se tiende, como regla general, a establecer relaciones que tienen más características vinculadas con la intimidad y solidaridad, que la distancia o el respeto. No obstante, en euskera, la edad sigue siendo un factor fundamental para la asimetría entre los familiares, lo cual difiere del español peninsular actual. Otra diferencia destacable es que en español se crean relaciones más distantes y respetuosas que en euskera, cuando existe una asimetría de poder social. 
Con todo esto, y teniendo en mente las limitaciones de este estudio, los resultados obtenidos del análisis y la comparación que se ha desarrollado en el presente estudio son datos empíricos dado que la parte del español se ha basado en la revisión de los estudios que ya han sido realizados por algunos eruditos (Montero Curiel, 2011; Sampedro Mella, 2016; Pedroviejo Esteruelas, 2006; Sanromán Vilas, 2010) acerca de la utilización de los pronombres de segunda persona del singular en el español peninsular; y en lo que al euskera respecta, el estudio que se ha realizado también se categoriza como empírico, aunque no se hayan analizado los usos de sus pronombres de segunda persona del singular en el habla real, sino a través de las conversaciones de la serie de ETB Goenkale. Así, teniendo en cuenta la validez de los estudios del español peninsular revisitados, y la magnitud, la constancia, y la uniformidad de las conversaciones analizadas en euskera, se cree que los resultados de la comparación se acercan con considerable fidelidad a la realidad de ambas comunidades de habla en el siglo actual.

En todo caso, aun siendo este un estudio empírico, sería conveniente realizar un estudio lingüístico dentro de la pragmática intercultural que tuviera como datos las conversaciones orales que se producen entre los hablantes de forma espontánea. De hecho, se podría abrir otra línea de investigación con hablantes bilingües -euskera y español- para analizar si en ambos idiomas utilizan los pronombres idénticos en cada contexto. Esto limitaría la parte del español a la variedad que se produce en el País Vasco, pero los resultados podrían ser más específicos y la comparación que se establecería sería más concreta. 


\section{REFERENCIAS}

Albelda Marco, M., \& Barros García, M. J. (2013). La cortesía en la comunicación. Madrid: Arco Libros.

Alberdi, J. (1991). Hikako tratamenduaren balore sozio-afektiboak. Fortes Linguae Vasconum, Studia et Documenta, 64, 425-442.

Alberdi, J. (1994). Hitanoa non eta nork erabiltzen duen. Euskera, XXXIX, 983-993.

Alberdi, J. (1995). The development of the Basque system of terms of address and the allocutive conjugation. In J. I. Hualde, J. A. Lakarra \& R. L. Trask (Eds.), Towards a history of the Basque language (pp. 275-293).

Alonso-Cortés, A. (1999). Las construcciones exclamativas: la interjección y las expresiones vocativas. In I. Bosque \& V. Demonte (Eds.), Gramática descriptiva de la lengua española, 3, 3995-4050.

Amorrortu, E. (2003). Basque sociolinguistics: Language, society and culture. Reno, NV: Center for Basque Studies.

Ardila, J. (2003). (Non-deictic, socio-expressive) T-/V-pronoun distinction in Spanish/ English formal locutionary acts. Forum for Modern Language Studies, 39, 74-86.

Blas Arroyo, J. L. (1994). De nuevo sobre el poder y la solidaridad. Apuntes para un análisis internacional de la alternancia tú/usted. Nueva revista de filología hispánica, 42(2), 385414.

Blas Arroyo, J. L. (1995). Tú y usted: dos pronombres de cortesía en el español actual. Datos de una comunidad peninsular. Revista ELUA, 10, 21-44. 
Blas Arroyo, J. L. (2005a). Los grados de la cortesía verbal: Reflexiones en torno a algunas estrategias y recursos lingüísticos en el español peninsular contemporáneo. Revista internacional de lingüistica iberoamericana, 3(1), 9-29.

Blas Arroyo, J. L. (2005b). Sociolingüística del español. Desarrollos y perspectivas en el estudio de la lengua española en contexto social. Madrid: Cátedra.

Bravo, D. (1999). ¿Imagen positiva vs. imagen negativa?: Pragmática social y componentes del face. Oralia 2, 155-184.

Bravo, D. (2003). Actividades de cortesía, imagen social y contextos socioculturales: Una introducción. In D. Bravo (Ed.), Actas del Primer Coloquio EDICE. La perspectiva no etnocentrista de la cortesía: identidad sociocultural de las comunidades hispanohablantes (pp. 98-108).

Brown, R., \& Gilman, A. (1960). The pronouns of power and solidarity. In T. A. Sebeok (Ed.), Style in Language (pp. 253-276).

Brown, P., \& Levinson, S. C. (1978). Universals of language usage: Politeness phenomena. In E. Goody (Ed.), Questions and politeness (pp. 56-289).

Brown, P., \& Levinson, S. C. (1987). Politeness: Some universals in language usage. Cambridge: Cambridge University Press.

Calderón Campos, M., \& Medina Morales, F. (2010). Historia y situación actual de los pronombres de tratamiento en el español peninsular. In M. Hummel, B. Kluge \& M. E. Vázquez Laslop (Eds.), Formas y fórmulas de tratamiento en el mundo hispánico (pp. 196-222).

Carandell, L. (1981). Tú y usted. Triunfo, 3, 84-85. 
Carrasco Santana, A. (2002). Los tratamientos en español. Salamanca: Ediciones Colegio de España.

Carricaburo, N. (1997). Las fórmulas de tratamiento en el español actual. Madrid : Arco Libros.

De Jonge, B. \& Nieuwenhuijsen, D. (2009). Formación del paradigma pronominal de las formas de tratamiento. In C. Company Company (Dir.), Sintaxis histórica de la lengua española. Segunda parte: la frase nominal (pp. 1595-1671).

De Jonge, B., \& Nieuwenhuijsen, D. (2012). Forms of address. In J. I. Hualde, A. Olarrea \& E. O’Rourke (Eds.), The handbook of Hispanic linguistics (pp. 247-262).

De Rijk, R. P. G. (1991). Familiarity or solidarity: The pronoun hi in Basque. Revista internacional de los estudios vascos, 36(2), 373-378.

De Rijk, R. P. G. (2008). Standard Basque: A progressive grammar (Vol. 1). Cambridge, MA: The MIT Press.

Echeverria, B. (2001). Privileging masculinity in the social construction of Basque identity. Nations and Nationalism, 7, 339-363.

Echeverria, B. (2003). Language ideologies and practices in (en)gendering the Basque nation. Language in society, 32, 383-413.

Echeverria, B. (2010). For whom does language death toll? Cautionary notes from the Basque case. Linguistics and Education, 21, 197-209.

Euskaltzaindia. (1985). Euskal gramatika: Lehen urratsak-I. Pamplona: Euskaltzaindia.

Euskaltzaindia. (2016). Lexikoaren behatokiaren corpusa (Corpus del observatorio léxico).

Fant, L. (1996). Regulación conversacional en la negociación: Una comparación entre pautas mexicanas y peninsulares. In T. Kotschi, W. Oesterreicher \& K. Zimmermann (Eds.), El español hablado y la cultura oral en España e Hispanoamérica (pp. 147-183). 
Fernández-Guerra, A. (2008). Requests in TV Series and in Naturally Occurring Discourse: A Comparison. In E. Alcón (Ed.), Learning How to Request in an Instructed Language Learning Context (pp. 111-126).

Fraser, B., \& Nolen, W. (1981). The association of deference with linguistic form. International Journal of the Sociology of Language, 27, 93-111.

García-Godoy, M. T. (2016). ¿Fue vulgar y plebeyo el origen de usted? La diacronía del pronombre de respeto desde la interfaz oral/escrito. Oralia, 19, 61-84.

Goffman, E. (1967). Interactional ritual: Essays on face to face behaviour. Garden City, NY: Anchor Books.

Gu, Y. (1990). Politeness phenomena in modern Chinese. Journal of Pragmatics, 14(2), 237257.

Haddican, B. (2003). Dialect contact in a Southern Basque town. Language Variation and Change, 15(1), 1-35.

Haddican, B. (2007). Suburbanization and language change in Basque. Language in society, $36(5), 677-706$.

Hofstede, G., Hofstede, G. J., Minkov, M. (2010). Cultures and Organizations. New York: McGraw Hill.

Ide, S. (1982). Japanese sociolinguistics: politeness and women's language. Lingua, 57, 357-385.

Ide, S. (1989). Formal forms and discernment: two neglected aspects of universals of linguistic politeness. Multilingua, 8(2/3), 223-248.

Ide, S. (1993). Linguistic politeness, III: linguistic politeness and universality. Multilingua, 12(1). 
Kite, Y., \& Tatsuki, D. (2005). Remedial Interactions in Film. In D. Tatsuki (Ed.), Pragmatics in Language Learning, Theory and Practice (pp. 99-118).

Laka, I. (1996). A brief grammar of euskara, the Basque language. Leioa: Euskal Herriko Unibertsitatea.

Lakoff, R. T. (1973). The logic of politeness; or minding your p's and q's. Papers from the regional meeting, Chicago Linguistic Society, 9, 292-305.

Lakoff, R. T. (1990). Talking power: the politics of language in our lives. New York: Basic Books.

Lambert, W. E., \& Tucker, G. R. (1976). Tu, vous, usted: A social-psychological study of address patterns. Rowley, MA: Newbury House Publishers, Inc.

Leech, G. N. (1977). Language and tact. L.A.U.T. paper 46. (Reprinted as Leech 1980).

Leech, G. N. (1980). Language and tact. Amsterdam: Benjamins.

Leech, G. N. (1983). Principles of pragmatics. Essex: Longman.

Leech, G. N. (2014). The pragmatics of politeness. New York: Oxford University Press.

León-Castro Gómez, M. (2014). Sobre el empleo de la segunda persona del singular como mecanismo de indefinición referencial en el habla culta. Diferencias entre las formas tú/vos y usted. Lingüística y literatura, 65, 37-63.

Levinson, S. C. (1983). Pragmatics. Cambridge: Cambridge University Press.

Lipski, J. M. (2012). Geographical and social varieties of Spanish: An overview. In J. I. Hualde, A. Olarrea \& E. O’Rourke (Eds.), The handbook of Hispanic linguistics (pp. 1-26).

Llorente Maldonado de Guevara, A. (1976). Las construcciones de carácter impersonal en español. Estudios ofrecidos a Emilio Alarcos Llorach, 1, 107-125.

Marín, D. (1972). El uso de “tú” y “usted” en el español actual. Hispania, 55(4), 904-908. 
Moliner, M. (1977). Diccionario de uso del español. Madrid: Gredos.

Montero Curiel, P. (2011). Aproximación sociolingüística a las fórmulas pronominales de tratamiento en el habla juvenil. Revista de Estudios de Juventud, 93, 105-116.

Nuzzo, E. (2015). Comparing Textbooks and TV Series as Sources of Pragmatic Input for Learners of Italian as a Second Language: The Case of Compliments and Invitations. In S. Gesuato, W. Cheng \& F. Bianchi (Eds.), Teaching, Learning and Investigating Pragmatics: Principles, Methods and Practices (pp. 85-107). Cambridge: Cambridge Scholars Publishing.

Páez Rovira, D., \& Zubieta, E. (2004). Dimensiones culturales. Individualismo - Colectivismo como síndrome cultural. In I. Fernández Sedano, S. Ubillos Landa, E. Zubieta \& D. Páez Rovira (Eds.), Psicología social, cultura y educación (pp. 1-17 in Chapter 3). Madrid: Pearson Educación.

Pedroviejo Esteruelas, J. M. (2006). Un estudio sociolingüístico. Sistemas de tratamiento de la juventud de Valladolid. Revista de estudios filológicos, 11.

Pharies, D. A. (2015). Breve historia de la lengua española. Chicago: The University of Chicago Press.

Pinto, D., \& de Pablos-Ortega, C. (2014). Seamos pragmáticos: Introducción a la pragmática española. New Have, CT: Yale University Press.

Placencia, M. E. (2005). Pragmatic variation in corner store interactions in Quito and Madrid. Hispania, 88(3), 583-598.

Quaglio, P. (2009). Television Diaglogue. The sitcom Friends vs. natural conversation. Amsterdam: Benjamins. 
Rose, K. R. (2001). Compliments and compliment responses in film: Implications for pragmatics research and language teaching. International Review of Applied Linguistics, 39, 309326.

Saltarelli, M. (1988). Basque. London: Croom Helm.

Sampedro Mella, M. (2016). Las formas de tratamiento 'tú y usted' en el español centro-norte peninsular. Estudio sociolingüístico. Salamanca: Ediciones Universidad de Salamanca.

Sanromán Vilas, B. (2010). Sociolingüística de los pronombres de segunda persona: estudio contrastivo entre dos ciudades españolas. Neuphilologische Mitteilungen, 111(4), 479502.

Serrano, M. J. (2017). Going beyond address forms: Variation and style in the use of the secondperson pronouns tú and usted. Pragmatics, 27, 87-114.

Solé, Y. R. (1978). Sociocultural determinants of symmetrical and asymmetrical address forms in Spanish. Hispania, 61(4), 940-949.

Soler-Espiauba, D. (1994). ¿Tú o usted? ¿Cuándo y por qué? Descodificación al uso del estudiante de español como lengua extranjera. Centro Virtual Cervantes, V, 199-208.

Spencer-Oatey, H. (2000). Culturally speaking: Managing rapport through talk across cultures. New York: Continuum.

Trask, R. L. (1997). The history of Basque. New York: Routledge.

Trask, R. L. (2003). The noun phrase: Nouns, determiners and modifiers; pronouns and names. In J. I. Hualde \& J. Ortiz de Urbina (Eds.), A grammar of Basque (pp. 113-170).

Vila, M. R. (1987). La segunda persona gramatical en función no deíctica. Revista Española de Lingüística (RSEL), 17, 57-68. 
Watts, R. J. (1989). Relevance and relational work: linguistic politeness as politic behavior. Multilingua, 8, 131-166.

Watts, R. J. (1992). Linguistic politeness and politic verbal behaviour: Reconsidering claims for universality. In R. J. Watts, S. Ide \& K. Ehlich (Eds.), Politeness in language: Studies in its history, theory and practice (pp. 43-69).

Watts, R. J. (2003). Politeness. New York: Cambridge University Press.

Wolpert, M., Mancini, S., \& Caffarra, S. (2017). Addressee Identity and Morphosyntactic Processing in Basque Allocutive Agreement. Frontiers in psychology, 8, 1-11.

Zlobina, A. (2004). Estereotipos nacionales y regionales en Europa y España. In I. Fernández Sedano, S. Ubillos Landa, E. Zubieta \& D. Páez Rovira (Eds.), Psicología social, cultura y educación (pp. 25-37 in Chapter 23). Madrid: Pearson Educación.

Zubiri, I., \& Zubiri, E. (2000). Euskal gramatika osoa. Bilbo: G. Z. Printek. 